\title{
Diversity of Myxomycetes in arid zones of Peru part II: the cactus belt and transition zones
}

\author{
Carlos LADO ${ }^{1, *}$, Diana WRIGLEY DE BASANTA ${ }^{2}$, Arturo ESTRADA-TORRES ${ }^{3}$, \\ Steven L. STEPHENSON ${ }^{4} \&$ I. TREVIÑO ${ }^{5}$ \\ ${ }^{1,2}$ Real Jardín Botánico de Madrid CSIC, Plz. de Murillo no. 2, 28014 Madrid, Spain. \\ ${ }^{3}$ Centro Tlaxcala de Biología de la Conducta, Universidad Autónoma de Tlaxcala, Av. Universidad no. 1, \\ La Loma Xicohténcatl, 90,062 Tlaxcala, Mexico. \\ ${ }^{4}$ Department of Biological Sciences, University of Arkansas, Fayetteville, AR 72701, United States of America. \\ ${ }^{5}$ Universidad Nacional de San Agustín de Arequipa, Av. Alcides Carrión s.n., Arequipa, Peru. \\ "Corresponding author: lado@rjb.csic.es, https://orcid.org/0000-0002-6135-2873 \\ ${ }^{2}$ dwbasanta@gmail.com, https://orcid.org/0000-0002-7700-8399 \\ 3. arturomixo@hotmail.com, https://orcid.org/0000-0001-5691-7844 \\ ${ }^{4}$ slsteph@uark.edu, https://orcid.org/0000-0002-9207-8037 \\ 5ifrant01@gmail.com, https://orcid.org/0000-0002-2406-7862
}

\begin{abstract}
The results obtained from a second survey for Myxomycetes in the arid areas of Peru are reported. A total of 37 localities from the cactus belt ('cardonal'), between 1500 and $3000 \mathrm{~m}$ a.s.l., were sampled over six years. This survey is based on 601 identifiable collections of myxomycetes, developed in the field under natural conditions or those that were recovered from moist chamber cultures. In total, 84 taxa representing 19 genera were recorded. One new species, Cribraria spinispora Lado \& D.Wrigley sp. nov., is described, three species new to South America and 22 additional new species for Peru are reported as well. Endemic plants, expecially cacti, had a particular relevance as myxomycete substrates. The predominance of the order Physarales T.Macbr. in arid areas is reinforced. Comments are included on some collections, as well as SEM micrographs of several species. A statistical evaluation of the diversity of myxomycetes in the cardonal area and a comparison of this area with the dry coastal desert of Peru and other Neotropical xeric environments are also included. Results show that the arid areas are rich in myxomycetes, and that each area has a unique assemblage. The differences appear to be related to the host plants.
\end{abstract}

Keywords. Amoebozoa, cactus belt, distribution, Eumycetozoa, plasmodia slime moulds.
Resumen. Se presentan los resultados de un segundo estudio sobre Myxomycetes de zonas áridas de Perú. Un total de 37 localidades del cardonal, situadas entre 1500 y 3000 m s.n.m., fueron muestreadas durante seis años. Este estudio está fundamentado en 601 recolecciones de mixomicetes, obtenidas en el campo o por cultivo en cámara húmeda. En total, se han identificado 84 táxones que corresponden a 19 géneros. Se describe una nueva especie, Cribraria spinispora Lado \& D.Wrigley sp. nov., además se registran por primera vez tres especies para Sudamérica y 22 para Perú. Las plantas endémicas, especialmente los cactus, han tenido una especial importancia como substrato para los mixomicetes. Se reafirma el predominio del orden Physarales T.Macbr. en zonas áridas. Se incluyen comentarios sobre algunas recolecciones, así como micrografías al MEB de algunas especies. Se realizó una evaluación estadística de la diversidad de mixomicetes en el cardonal y una comparación entre esta zona, la costa seca de Perú y otros ambientes neotropicales xéricos. Los resultados muestran que las zonas áridas son ricas en mixomicetes y que cada una tiene un conjunto exclusivo de especies. Las diferencias parecen estar relacionadas con las plantas anfitrionas.

Palabras clave. Amoebozoa, cardonal, distribución, Eumycetozoa, hongos mucilaginosos plasmodiales.

How to cite this article: Lado C., Wrigley de Basanta D., Estrada-Torres A., Stephenson S.L. \& Treviño I. 2019. Diversity of Myxomycetes in arid zones of Peru part II: the cactus belt and transition zones. Anales del Jardin Botánico de Madrid 76 (2): e083. https://doi.org/10.3989/ajbm.2520

Title in Spanish: Diversidad de Myxomycetes en zonas áridas de Perú, parte II: el cardonal y las zonas de transición.

Received: 11-I-2019; accepted: 30-IV-2019; published on-line: 28-X-2019; Associate Editor: M. Dueñas.

\section{INTRODUCTION}

The Myxomycetes G.Winter or plasmodial slime moulds are a group of microorganisms considered as a protozoan fungal analogue (Kirk \& al. 2011). The Myxomycetes have been found in all terrestrial ecosystems, and more than 1,000 species are currently recognized (Lado 2005-2018). The myxobiota of the arid or semi-arid environments, despite the lack of water, is surprisingly high, since they develop adaptive strategies to survive in these extreme environments, as exemplified by the succulenticolus myxomycetes (Lado \& al. 1999). A total of 191 different species have been reported by our team from arid regions of the Neotropics (Lado \& al. 2007a, 2011, 2013, 2016; Estrada-Torres \& al. 2009; Wrigley de Basanta \& al. 2011, 2012). The elevated numbers of myxomycete species is particularly interesting, since 24 of the species found in these surveys were previously unknown, and have been described as new to science (Lado \& al. 1999, 2007b, 
2009, 2011, 2013, 2014; Estrada-Torres \& al. 2001, 2009; Wrigley de Basanta \& al. 2008b, 2009, 2010a, 2011, 2012, 2015, 2018, 2019).

The only data on the myxobiota of arid areas of Peru was published by Lado \& al. (2016), and was from a survey conducted in the coastal desert, below $1500 \mathrm{~m}$ a.s.l. This second contribution complements and extends the previously mentioned work, and refers to a survey of locations on the Pacific slope of the Peruvian Andes, at elevations between 1500-3000 $\mathrm{m}$ a.s.l., providing the second dataset on the myxomycetes of the drylands of this country.

The ecoregion to be included in the study was the Peruvian 'cardonal', an extremely arid area populated by columnar cacti (Cactaceae Juss.) and associated plants that lies in a belt between the coastal desert and the western slopes of the Andes, and covers approximately the $2 \%$ of the entire national territory. This area, receives less than $500 \mathrm{~mm}$ of rain annually, is not reached by the humidity provided by the 'garuas' or coastal fogs, and is under the rain shadow effect of the Andean mountain range. This means that the aridity is extreme and only cacti and other adapted plants survive. These plants are potential substrates for myxomycetes, providing rich and varied microhabitats in which these organisms can complete their development.

The area covered is a long and narrow strip of Peruvian territory from Ecuador to Chile. The samples were taken from different localities of the departments of Piura, Cajamarca, La Libertad, Ancash, Lima, Huancavelica, Apurimac, Huanuco, Cusco, Arequipa, Moquegua and Tacna. The cardonal vegetation is dominated by scattered cacti of the genera Armatocereus Backeb., Corryocactus Britton \& Rose, Browningia Britton \& Rose, Echinopsis Zucc., Espostoa Britton \& Rose, Haageocereus Backeb., Melocactus Link \& Otto, Neoraimondia Britton \& Rose, Opuntia Mill. and Weberbauerocereus Backeb. (fig. 1). Many of the species are endemic and some of them can reach five meters in height, while others are prostrate (Ostolaza 2014). Mixed with the cacti, sparsely distributed bushes and some herbaceous species, that complete their vegetative cycle during the short period of rain, can be found. Some of these bushes lose their leaves during the dry period of the year. The commonest species belong to the genera Ambrosia L., Baccharis L., Grindelia Willd., Mutisia L. f. and Senecio L. (Asteraceae Bercht. \& J.Presl), Cnidoscolus Pohl and Jatropha L. (Euphorbiaceae Juss.), Heliotropium L. (Boraginaceae Juss.), Tarasa Phil. (Malvaceae Juss.) and Tecoma Juss. (Bignoniaceae Juss.). In the upper limit of the 'cardonal', there are zones of transition with the presence of shrubs and other plants characteristic of the Andean 'altiplano'(MINAM 2015).

\section{MATERIAL AND METHODS}

Sampling was carried out in 37 localities, in six expeditions that took place in September to October 2012, April 2013, May 2014, April 2016, April 2017 and May 2018 (fig. 2). At each locality, the microhabitats in which myxomycetes are known or suspected to occur were examined carefully. All localities were geo-referenced with a portable GPS unit (Garmin eTrex Vista HCX, Datum WGS84). The samples were collected in the field and substrate samples were also removed for moist chamber culture. The methods used for collecting myxomycetes in the field and substrates for laboratory culture can be found in Rossman \& al. (1998) and Wrigley de Basanta \& Estrada-Torres (2017). All the fieldwork was carried out by A. Estrada-Torres and C. Lado, with the help of D. Wrigley de Basanta, S.L. Stephenson, A. Rollins, G. Rebaza and I. Treviño in 2012, with D. Wrigley de Basanta, J.M García-Martín and A. Cano in 2013, with D. Wrigley de Basanta, J. Rojas-Fox, J. Molina and S. Castillo in 2014, with D. Wrigley de Basanta and I. Treviño in 2016, and with I. García-Cunchillos and I. Treviño in 2017 and 2018. Up to four investigators collected at any one time with approximately one hour spent in each collecting locality.

The moist chamber cultures were prepared in the manner described by Wrigley de Basanta \& al. (2009). The pH of each culture was determined after $24 \mathrm{~h}$, and the cultures were maintained at room temperature $\left(21-25^{\circ} \mathrm{C}\right)$ in diffuse daylight and examined at regular intervals for a period of up to three months. As the myxomycete sporophores were formed, the portion of the substrate upon which they occurred was removed from the moist chamber culture, allowed to dry slowly in a closed empty Petri dish and then glued into a small cardboard box. All sporophores of a given species that developed in the same culture were considered to represent a single record. All microscope measurements and observations were made with material mounted directly in Hoyer's medium or polyvinyl alcohol (PVA). Differential interference contrast (DIC) microscopy was used to obtain descriptive data. Some specimens were examined, in the Real Jardín Botánico de Madrid CSIC, with a Hitachi S-3000N scanning electron microscope (SEM) at 10-15 kV. For all SEM-photographs the critical point dried material technique was employed. Colour notations in parenthesis are from the ISCC-NBS Color Name Charts Illustrated with Centroid Colors (Kelly \& Judd 1976).

The ACE and the CHAO1 abundance indices (Colwell \& Coddington 1994; Colwell \& al. 2004) were used to estimate how complete the sampling effort was. The accumulation curve was adjusted according to the Clench function, where ' $S_{n}=(a \cdot n) /[1+(b \cdot n)]$ ', where ' $\mathrm{S}$ ' ' is the number of species accumulated for a unit of collecting effort ('n') (Jiménez-Valverde \& Hortal 2003). Each collecting site was considered as the unit of collecting effort, using the total number of species found with the 

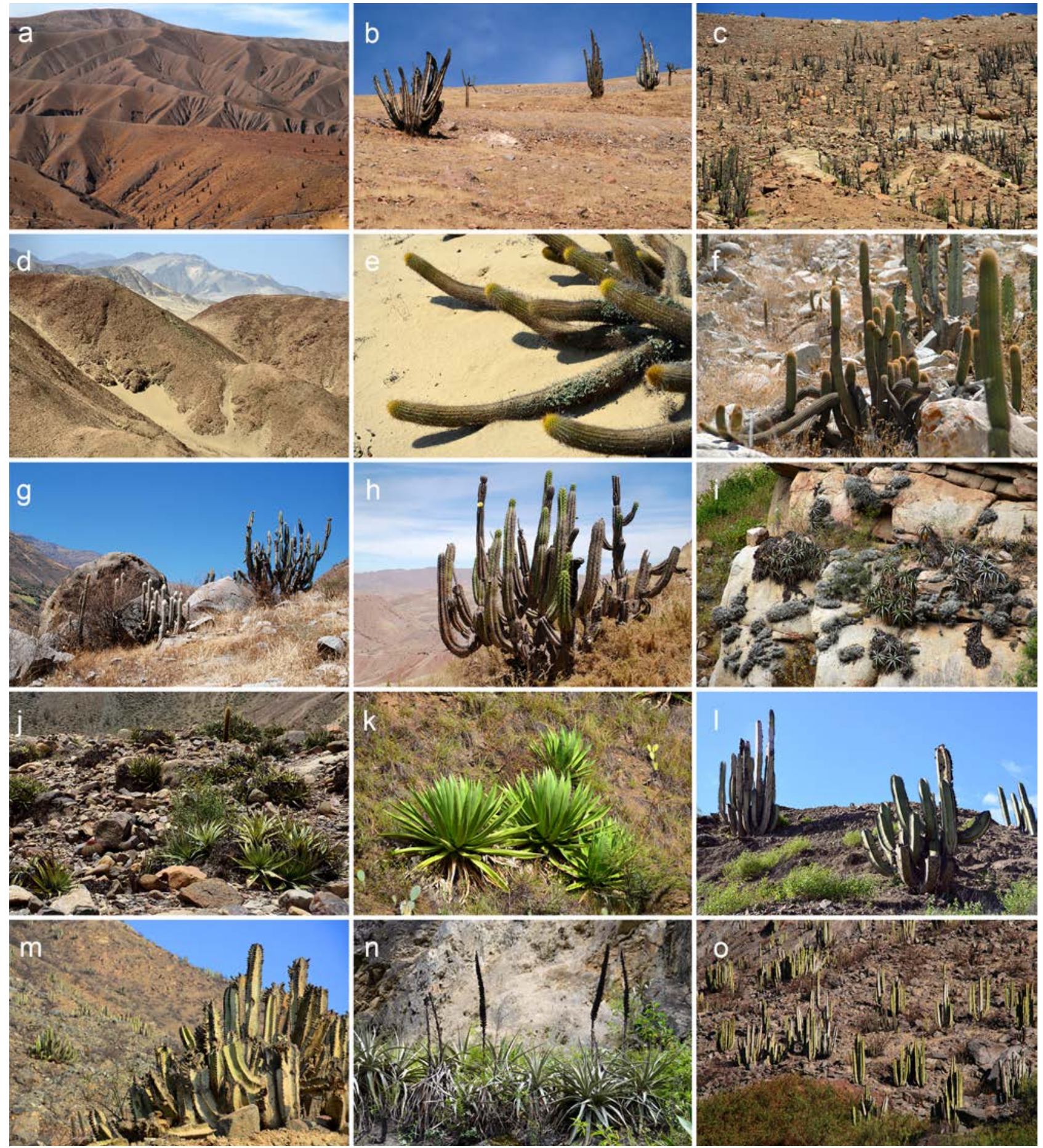

Fig. 1. Landscapes and some vegetation types of the Peruvian 'cardonal': a, b, landscape of the hills of Moquegua and Arequipa with some dispersed cacti such as Browningia candelaris (Meyen) Britton \& Rose and Neoraimondia arequipensis (Meyen) Backeb.; c, columnar cacti of Armatocereus sp.; d, arid ravines with sandy hummocks; e, prostrate cacti of Haageocereus sp. in sandy soils; $\mathbf{f}$, columnar cacti of Haageocereus sp. and Neoraimondia arequipensis on rocky soils; g, cardonal of Espostoa sp. and Armatocereus sp. at the top of the rocky slopes; $\mathbf{h}$, Corryocactus brevistylus (K.Schum. ex Vaupel) Britton \& Rose near Arequipa; i, bromeliads of the genera Puya Molina and Tillandsia L. on rock faces; j, specimens of Furcraea andina Trel. found in the central area of Peru; k, arid valleys with Melocactus peruvianus Vaupel, Weberbauerocereus sp. and Puya sp. l-m, Neoraimondia arequipensis mixed with grasses and small shrubs; n, Puya sp. with dead leaves and inflorescences; o, rocky slopes with columnar cacti of Neoraimondia arequipensis. 
program EstimateS v. 9.1.0 (Colwell 2013), adjusted so that ' 3 ' was the upper abundance limit for rare or infrequent species, following the criteria of Stephenson \& al. (1993) and considering the species with a relative abundance less than or equal to 0.05 to be rare. With the same program, the richness of species with 1.5 times more sampling effort was calculated. The adjustment according to the Clench function was carried out with the program Statistica v. 12, using the Simplex and Quasi-Newton method of adjustment (Jiménez-Valverde and Hortal 2003). ACE and CHAO1 abundance indices were calculated for all results, only field results and only moist chamber culture results.

To compare the results from this area with those of other studies carried out in arid areas in the Americas by the same team, the complementarity has been calculated, using the formula proposed by Colwell \& Coddington (1994): ' $\mathrm{C}_{\mathrm{jk}}=\mathrm{U}_{\mathrm{jk}} / \mathrm{S}_{\mathrm{jk}}$ ', where ' $\mathrm{U}_{\mathrm{jk}}=\mathrm{S}_{\mathrm{j}}+\mathrm{S}_{\mathrm{k}}-\left(2 \mathrm{~V}_{\mathrm{jk}}\right)$ ' and
' $\mathrm{S}_{\mathrm{jk}}=\mathrm{S}_{\mathrm{j}}+\mathrm{S}_{\mathrm{k}}-\mathrm{V}_{\mathrm{jk}}$ ', where ' $\mathrm{U}_{\mathrm{jk}}$ ' is the number of species that are different for the two communities, ' $\mathrm{S}_{\mathrm{jk}}$ ' is the total richness of species for both communities, ' $\mathrm{S}_{\mathrm{j}}$ ' is the number of species from the first community, ' $\mathrm{S}_{\mathrm{k}}$ ' is the number of species from the second and ' $\mathrm{V}_{\mathrm{jk}}$ ' is the number of species common to both.

A test of independence was done using a contingency table and a $\chi^{2}$ test (Zar 1996) to determine whether the proportion of the collections, and the species from different orders of myxomycetes was dependent on the sampling method used, or whether these were due to the vegetation type of the survey area. If there was a difference, a standardized residual analysis was done to see if the proportions were statistically significant between the observed and expected values (Sheskin 2004).

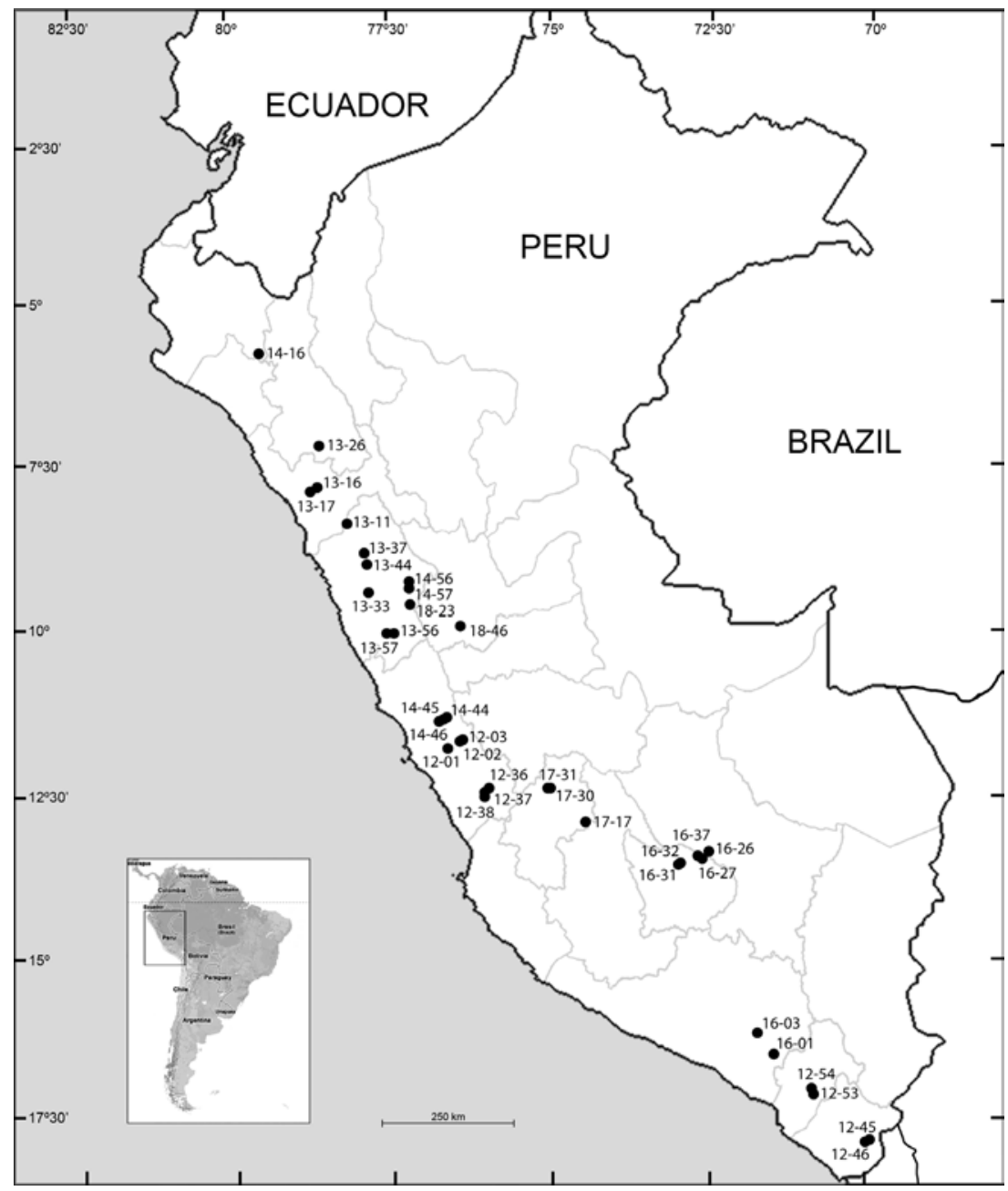

Fig. 2. Map of the general study area, numbers refer to localities sampled in six expeditions: 12-01 to 12-54, Lima, Moquegua and Tacna (Sep. to Oct. 2012); 13-11 to 13-57, Ancash, Cajamarca and La Libertad (Apr. 2013); 14-16 to 14-57, Ancash, Lima and Piura (May 2014); 16-01 to 16-37, Apurimac, Arequipa and Cusco (Apr. 2016); 17-17 to 17-31, Huancavelica (Apr. 2017); 18-23 to 18-46, Ancash and Huánuco (May 2018). 
All specimens are deposited in the herbarium MAFungi (sub C. Lado) with duplicates in the herbaria TLXM (sub A. Estrada-Torres), UARK (sub S.L. Stephenson) or in the private collection of D. Wrigley de Basanta ('dwb').

\section{RESULTS}

As a result of the survey of these arid and semiarid areas carried out in six different years, 601 collections of myxomycetes, either specimens that had developed in the field or those that were recovered from moist chamber cultures, were identified. In total, 84 taxa representing 19 genera of myxomycetes were recorded. Of these, one is a new species of the genus Cribraria Pers., 1794 that is described below, three are new records for South America, namely Didymium umbilicatum D.Wrigley \& al., Hemitrichia succulenticola G.Moreno \& al. and Stemonitopsis amoena (Nann.-Bremek.) Nann.-Bremek., and 22 more are new records for Peru.

The myxomycete collections from this survey are arranged alphabetically in the list that follows by genus and then species. Nomenclature follows Lado (2005-2018) unless otherwise stated. Information is provided on the locality from which each record was collected, the substrate upon which it was collected, the source of each record (either a field collection or a collection obtained from a moist chamber culture), and the $\mathrm{pH}$ of the moist chamber culture in which the specimen appeared. All dates given are substrate collection dates, with the exception of the new species, in which the dates are those obtained in moist chamber culture. All identified collections are included with comments on their distribution. The distribution of the species in the Neotropics is based on Lado \& Wrigley de Basanta (2008), but the information on the area of study has been updated with added references. New records for South America or Peru are marked with a degree symbol or an asterisk, respectively. Species of particular interest have additional taxonomic comments.

\section{* Arcyria affinis Rostaf.}

Specimens examined.-PERU. Apurimac: Abancay, Puente Cunyac over the Apurímac river, route PE-3S, km. 869, community Ccarhua, $13^{\circ} 33^{\prime} 55^{\prime \prime} \mathrm{S}, 72^{\circ} 34^{\prime 2} 28^{\prime \prime} \mathrm{W}, 1936 \mathrm{~m}$ a.s.1., wood, 18 Apr. 2016, C. Lado 24509 leg. (MA-Fungi 91609); same data as for preceeding, C. Lado 24510 leg. (MA-Fungi 91610).

Notes.-In the Neotropics, it was previously reported from Ecuador, Mexico and Chile, but this is the first record from Peru. Only two collections from the same locality, the specimens agree with the description provided by Nannenga-Bremekamp (1991), except for the more prominent ornamentation of the capillitium.

\section{Arcyria afroalpina Rammeloo}

Specimens examined.-PERU. Ancash: Pallasca, Ancos, route PE-3N, km. 104, Cocabal, 08 29'24.7" S, 7806'32.5" W, 1605 m a.s.1., leaves of Puya sp., 11 Apr. 2013, C. Lado 22403 leg. (MA-Fungi 90908); same data as for preceeding, C. Lado 22405 leg. (MA-Fungi 90909); same data as for preceeding, C. Lado 22407 leg. (MA-Fungi 90911); same data as for preceeding, C. Lado 22408 leg. (MA-Fungi 90912). La Libertad: Otuzco, Plazapalpa, route PE-10A, km. 56, at the junction to Salpo, 0759'19.1" S, 78 39'21.2" W, 1742 m a.s.1., leaves of Furcraea andina, 12 Apr. 2013, C. Lado 22444 leg. (MA-Fungi 90940). Lima: Yauyos, Calachota, route PE-24, km. 104, 12 $38^{\prime} 55.5^{\prime \prime} \mathrm{S}, 75^{\circ} 58^{\prime} 01.8^{\prime \prime} \mathrm{W}, 1700 \mathrm{~m}$ a.s.1., leaf of Puya sp., moist chamber culture pH 7.39, 1 Oct. 2012, D. Wrigley de Basanta 3623 leg. (dwb).

Notes. - In Peru, it was previously reported by Rojas \& al. (2011) and Rojas \& Stephenson (2013) from the tropical forest, and by Lado \& al. (2016) from the coastal desert (Ancash, Arequipa).

\section{Arcyria cinerea (Bull.) Pers.}

Specimens examined.-PERU. Ancash: Huaylas, Caraz, Pueblo Libre, route $\mathrm{AN}-104, \mathrm{~km} .141,09^{\circ} 05^{\prime} 59.8^{\prime \prime} \mathrm{S}, 77^{\circ} 48^{\prime} 01.5^{\prime \prime} \mathrm{W}, 2466 \mathrm{~m}$ a.s.l., inflorescence of Puya angusta, moist chamber culture $\mathrm{pH} 7.76,20$ Apr. 2013, A. Estrada-Torres 13117 leg. (TLXM); Bolognesi, Raquia,

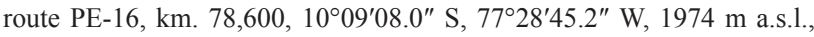
inflorescence of Tillandsia purpurea, moist chamber culture $\mathrm{pH} 5.61,24$ Apr. 2013, A. Estrada-Torres 13122 leg. (TLXM). La Libertad: Otuzco, Plazapalpa, route PE-10A, km. 56, at the junction to Salpo, $07^{\circ} 59^{\prime} 19.1^{\prime \prime}$ S, 78 39'21.2" W, $1742 \mathrm{~m}$ a.s.1., leaves of Puya sp., 12 Apr. 2013., C. Lado 22455 leg. (MA-Fungi 90953); same data as for preceeding, $C$. Lado 22469 leg. (MA-Fungi 90969); same data as for preceeding, $C$. Lado 22472 leg. (MA-Fungi 90971); same data as for preceeding, $C$. Lado 22473 leg. (MA-Fungi 90972). Lima: Huarochirí, San Bartolomé, $11^{\circ} 54^{\prime} 33.3^{\prime \prime} \mathrm{S}, 76^{\circ} 31^{\prime} 34.0^{\prime \prime} \mathrm{W}, 1580 \mathrm{~m}$ a.s.1., twigs, moist chamber culture pH 6.4, 22 Sep. 2012, S.L. Stephenson 30064 leg. (UARK); same data as for preceeding, moist chamber culture pH 6.4, S.L. Stephenson 30071 leg. (UARK); same data as for preceeding, moist chamber culture $\mathrm{pH}$ 6.43, S.L. Stephenson 30221 leg. (UARK); Huarochirí, Matucana, Chacahuaro,

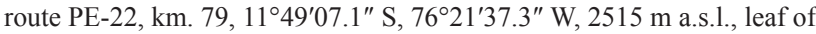
Agave americana, 23 Sep. 2012., C. Lado 21715 leg. (MA-Fungi 90775);

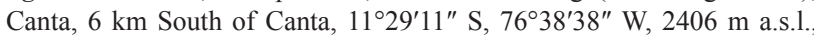
leaves of Furcraea andina, 18 May 2014, C. Lado 23638 leg. (MA-Fungi 91140); same data as for preceeding, C. Lado 23639 leg. (MA-Fungi 91141). Piura: Huancabamba, route PE-04E, km. 49, Abra Porcuya, $5^{\circ} 50^{\prime} 28^{\prime \prime} \mathrm{S}, 79^{\circ} 29^{\prime} 22^{\prime \prime} \mathrm{W}, 2005 \mathrm{~m}$ a.s.l., leaf litter, 10 May 2014, C. Lado 23452 leg. (MA-Fungi 91072); same data as for preceeding, wood, $C$. Lado 23457 leg. (MA-Fungi 91077).

Notes.-Widely distributed in Peru, it is known from Loreto, Madre de Dios, Arequipa, Ancash and Ica (Wrigley de Basanta \& al. 2008a; Rojas \& Stephenson 2013; Lado \& al. 2016)

\section{Arcyria denudata (L.) Wettst.}

Specimens examined.-PERU. Ancash: Pallasca, Ancos, route PE$3 \mathrm{~N}, \mathrm{~km}$ 104, Cocabal, 08²9'24.7" S, 7806'32.5" W, $1605 \mathrm{~m}$ a.s.l., inflorescence of Puya sp., moist chamber culture pH 5.9, 11 Apr. 2013, A. Estrada-Torres 13009 leg. (TLXM); Huaraz, Pariacoto, route PE-14, km 79, 09³2'16.1" S, 7746'07.4" W, 2569 m a.s.1., leaves of Agave americana, 17 Apr. 2013, C. Lado 22670 leg. (MA-Fungi 91008). La Libertad: Otuzco, Plazapalpa, route PE-10A, km 56, at the junction to Salpo, 0759'19.1" S, 78³9'21.2" W, 1742 m a.s.l., leaves of Puya sp., 12 Apr. 2013, C. Lado 22454 leg. (MA-Fungi 90952).

Notes.-In Peru it is only known from Junín and Madre de Dios (Zúñiga 2010; Rojas \& Stephenson 2013), Farr (1976) also reported a collection of this species preserved in BPI, but without a precise location. A search for this specimen in the database of this herbarium was unfruitful. 


\section{Arcyria insignis Kalchbr. \& Cooke}

Specimens examined.-PERU. La Libertad: Otuzco, Plazapalpa, route PE-10A, km 56, at the junction to Salpo, 0759'19.1" S, 78 39'21.2" W, 1742 m a.s.l., leaves of Puya sp., 12 Apr. 2013, C. Lado 22453 leg. (MA-Fungi 90951). Lima: Yauyos, Yauyos, Auco, route PE-24, km $110,12^{\circ} 36^{\prime} 45.3^{\prime \prime} \mathrm{S}, 75^{\circ} 58^{\prime} 31.6^{\prime \prime} \mathrm{W}, 1775 \mathrm{~m}$ a.s.1., twigs, moist chamber culture pH 6.85, 1 Oct. 2012, S.L. Stephenson 28319 leg. (UARK). Piura: Huancabamba, route PE-04E, km 49, Abra Porcuya, 550'28" S, 79²9'22" W, 2005 m a.s.l., twigs, 10 May 2014, C. Lado 23450 leg. (MA-Fungi 91070); same data as for preceeding, C. Lado $23454 \mathrm{leg}$ (MA-Fungi 91074); same data as for preceeding, C. Lado 23459 leg. (MA-Fungi 91079); same data as for preceeding, wood, C. Lado 23475 leg. (MA-Fungi 91095).

Notes.-In Peru it was previously reported from Ancash, Arequipa, Lima and Piura (Lado \& al. 2016).

\section{Badhamia macrocarpa (Ces.) Rostaf.}

Specimens examined.-PERU. Tacna: Palca, Huanune, route PE-40, km

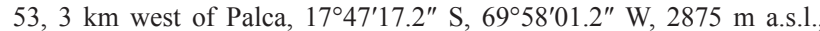
litter of Haageocereus sp., 5 Oct. 2012, C. Lado 22118 leg. (MA-Fungi 90854); Pachia, Los Olivares, route PE-40, km 43, 13 km west of Palca, $17^{\circ} 48^{\prime} 51.5^{\prime \prime} \mathrm{S}, 70^{\circ} 00^{\prime} 33.3^{\prime \prime} \mathrm{W}, 2345 \mathrm{~m}$ a.s.1., litter of Haageocereus sp., 5 Oct. 2012, C. Lado 22125 leg. (MA-Fungi 90864); same data as for preceeding, C. Lado 22126 leg. (MA-Fungi 90865).

Notes.-This is the second records of this species from Peru; it was previously reported also from Lima, in the lomas formations of the coastal desert (Lado \& al. 2016).

\section{Badhamia melanospora Speg.}

Specimens examined.-PERU. Ancash: Pallasca, Ancos, route PE-3N, km 104, Cocabal, 08²9'24.7" S, 7806'32.5" W, 1605 m a.s.l., litter of Melocactus sp., 11 Apr. 2013, C. Lado 22396 leg. (MA-Fungi 90902); same data as for preceeding, C. Lado 22397 leg. (MA-Fungi 90903); same data as for preceeding, C. Lado 22398 leg. (MA-Fungi 90904); same data as for preceeding, litter of Haageocereus sp., C. Lado 22400 leg. (MA-Fungi 90905); Huaylas, Caraz, Sucre, route PE-3N, km 665 , $08^{\circ} 56^{\prime} 12.7^{\prime \prime} \mathrm{S}, 77^{\circ} 50^{\prime} 30.8^{\prime \prime} \mathrm{W}, 2044 \mathrm{~m}$ a.s.l., leaves of Schinus molle, 18 Apr. 2013, C. Lado 22757 leg. (MA-Fungi 91023); same data as for preceeding, litter of Austrocylindropuntia sp., C. Lado 22784 leg. (MAFungi 91030); Huaylas, Caraz, Pueblo Libre, route AN-104, km 141, $09^{\circ} 05^{\prime} 59.8^{\prime \prime} \mathrm{S}, 77^{\circ} 48^{\prime} 01.5^{\prime \prime} \mathrm{W}, 2466 \mathrm{~m}$ a.s.1., cladode of Opuntia ficusindica, bryophytes and twigs, 20 Apr. 2013, C. Lado 22939 leg. (MAFungi 91042); same data as for preceeding, inflorescence of Puya angusta, C. Lado 22947 leg. (MA-Fungi 91050); same data as for preceeding, litter of Armatocereus matucanensis, C. Lado 22951 leg. (MA-Fungi 91054); same data as for preceeding, C. Lado 22952 leg. (MA-Fungi 91055). Apurimac: Abancay, $5 \mathrm{~km}$ from the Cunyac bridge, route PE-3S, km 864 , $13^{\circ} 33^{\prime} 01^{\prime \prime} \mathrm{S}, 72^{\circ} 36^{\prime} 43^{\prime \prime} \mathrm{W}, 1954 \mathrm{~m}$ a.s.1., litter of Browningia viridis, 21 Apr. 2016, C. Lado 24607 leg. (MA-Fungi 91616). Arequipa: Arequipa, Yarabamba, Quequeña, 16 $33^{\prime} 10^{\prime \prime}$ S, 71 ${ }^{\circ} 27^{\prime} 32^{\prime \prime}$ W, $2510 \mathrm{~m}$ a.s.l., litter of Austrocylindropuntia sp., 11 Apr. 2016, C. Lado 24225 leg. (MA-Fungi 91611); Arequipa, Yura Viejo, 16 ${ }^{\circ} 13^{\prime} 02^{\prime \prime}$ S, 71 ${ }^{\circ} 42^{\prime} 03^{\prime \prime}$ W, $2615 \mathrm{~m}$ a.s.1., litter of Weberbauerocereus weberbaueri, 12 Apr. 2016, C. Lado 24250 leg. (MA-Fungi 91612); same data as for preceeding, C. Lado 24251 leg. (MA-Fungi 91613); same data as for preceeding, C. Lado 24252 leg. (MA-Fungi 91614); same data as for preceeding, C. Lado 24253 leg. (MA-Fungi 91615). Huancavelica: Angaraes, route PE-26B, km $158,4 \mathrm{~km}$ west of Laramate, $13^{\circ} 01^{\prime} 48^{\prime \prime} \mathrm{S}, 7^{\circ} 23^{\prime} 48^{\prime \prime} \mathrm{W}, 2890 \mathrm{~m}$ a.s.1., cladode of Opuntia ficus-indica, 22 Apr. 2017, C. Lado 25040 leg. (MAFungi 91617); same data as for preceeding, C. Lado 25041 leg. (MAFungi 91618); Tayacaja, route PE-3S, km 193, Izcuchaca, $2 \mathrm{~km}$ south of Izcuchaca, 12 $30^{\prime} 23^{\prime \prime} \mathrm{S}, 74^{\circ} 58^{\prime} 40^{\prime \prime} \mathrm{W}, 2856 \mathrm{~m}$ a.s.1., cladode of Opuntia ficus-indica, 25 Apr. 2017, C. Lado 25257 leg. (MA-Fungi 91619). Lima:

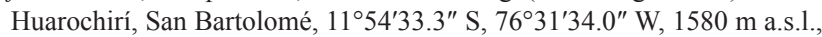

epidermis of Haageocereus acranthus, moist chamber culture $\mathrm{pH} 7.82$, 22 Sep. 2012, D. Wrigley de Basanta 3601 leg. (dwb); same data as for preceeding, moist chamber culture $\mathrm{pH} 8.22$, D. Wrigley de Basanta 3607 leg. (dwb); same data as for preceeding, litter of Haageocereus sp., C. Lado 21704 leg. (MA-Fungi 90762); same data as for preceeding, C. Lado 21705 leg. (MA-Fungi 90763); same data as for preceeding, C. Lado 21706 leg. (MA-Fungi 90765); same data as for preceeding, cladode of Opuntia sp., C. Lado 21708 leg. (MA-Fungi 90768); same data as for preceeding, C. Lado 21709 leg. (MA-Fungi 90769); same data as for preceeding, C. Lado 21710 leg. (MA-Fungi 90770); same data as for preceeding, C. Lado 21711 leg. (MA-Fungi 90771); Huarochirí,

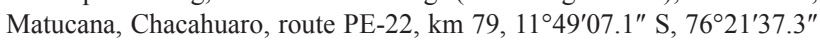
W, 2515 m a.s.1., aerial litter, moist chamber culture pH 6.37, 23 Sep. 2012, S.L. Stephenson 28856 leg. (UARK); Yauyos, Yauyos, route PE-24, km $124,12^{\circ} 31^{\prime} 56.7^{\prime \prime} \mathrm{S}, 75^{\circ} 54^{\prime} 52.6^{\prime \prime} \mathrm{W}, 2180 \mathrm{~m}$ a.s.1., litter of Haageocereus acranthus, 1 Oct. 2012, C. Lado 22005 leg. (MA-Fungi 90825); same data as for preceeding, C. Lado 22006 leg. (MA-Fungi 90826); same data as for preceeding, C. Lado 22008 leg. (MA-Fungi 90828); same data as for preceeding, twigs, moist chamber culture pH 6.06, S.L. Stephenson 28359 leg. (UARK); twigs, moist chamber culture $\mathrm{pH}$ 6.06, S.L. Stephenson 28431 leg. (UARK); Yauyos, Yauyos, Auco, route PE-24, km $110,12^{\circ} 36^{\prime} 45.3^{\prime \prime} \mathrm{S}, 7^{\circ} 58^{\prime} 31.6^{\prime \prime} \mathrm{W}, 1775 \mathrm{~m}$ a.s.1., litter of Haageocereus acranthus, 1 Oct. 2012, C. Lado 22014 leg. (MA-Fungi 90834); same data as for preceeding, C. Lado 22015 leg. (MA-Fungi 90835); same data as for preceeding, C. Lado 22016 leg. (MA-Fungi 90836); same data as for preceeding, C. Lado 22017 leg. (MA-Fungi 90837); same data as for preceeding, twigs, moist chamber culture pH 6.76, S.L. Stephenson 28356 leg. (UARK); Yauyos, Calachota, route PE-24, km 104, 12³8'55.5” S, $75^{\circ} 58^{\prime} 01.8^{\prime \prime} \mathrm{W}, 1700 \mathrm{~m}$ a.s.1., Tillandsia sp., moist chamber culture $\mathrm{pH}$ 6.14, 1 Oct. 2012, S.L. Stephenson 29173 leg. (UARK); same data as for preceeding, moist chamber culture pH 6.64, S.L. Stephenson 29177 leg. (UARK); Canta, $2 \mathrm{~km}$ south of Canta, $11^{\circ} 28^{\prime} 30^{\prime \prime} \mathrm{S}, 76^{\circ} 37^{\prime} 45^{\prime \prime} \mathrm{W}, 2700 \mathrm{~m}$ a.s.1., cladode of Opuntia sp., 18 May 2014, C. Lado 23631 leg. (MAFungi 91133); Canta, Canta, $11 \mathrm{~km}$ south of Huamantanga, $11^{\circ} 30^{\prime} 05^{\prime \prime} \mathrm{S}$, 76 40'02" W, 2204 m a.s.1., litter of Armatocereus sp., 18 May 2014, C. Lado 23646 leg. (MA-Fungi 91148). Moquegua: Mariscal Nieto, Torata, Torata, route PE-34D, km 24, 1707'14.4" S, 7050'26.9" W, $1991 \mathrm{~m}$ a.s.1., litter of Haageocereus sp., 7 Oct. 2012, C. Lado 22141 leg. (MA-Fungi 90879); same data as for preceeding, C. Lado 22142 leg. (MA-Fungi 90880); same data as for preceeding, litter of Browningia candelaris, $C$. Lado 22143 leg. (MA-Fungi 90881); same data as for preceeding, litter of Neoraimondia arequipensis, C. Lado 22144 leg. (MA-Fungi 90882); same data as for preceeding, C. Lado 22145 leg. (MA-Fungi 90883); same data as for preceeding, C. Lado 22146 leg. (MA-Fungi 90884); same data as for preceeding, C. Lado 22147 leg. (MA-Fungi 90885); same data as for preceeding, C. Lado 22148 leg. (MA-Fungi 90886); Mariscal Nieto,

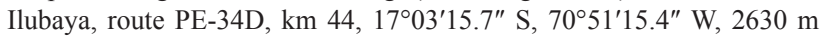
a.s.1., litter of Weberbauerocereus weberbaueri, 7 Oct. 2012, C. Lado 22152 leg. (MA-Fungi 90888); same data as for preceeding, C. Lado 22153 leg. (MA-Fungi 90891); same data as for preceeding, C. Lado 22156 leg. (MA-Fungi 90894); same data as for preceeding, C. Lado 22157 leg. (MA-Fungi 90895); same data as for preceeding, litter of Corryocactus brevistylus, C. Lado 22158 leg. (MA-Fungi 90896); same data as for preceeding, C. Lado 22159 leg. (MA-Fungi 90897); same data as for preceeding, C. Lado 22161 leg. (MA-Fungi 90899); same data as for preceeding, litter of Weberbauerocereus weberbaueri, C. Lado 22162 leg. (MA-Fungi 90900); same data as for preceeding, C. Lado 22163 leg. (MA-Fungi 90901). Tacna: Palca, Huanune, route PE-40, km 53, $3 \mathrm{~km}$ west of Palca, $17^{\circ} 47^{\prime} 17.2^{\prime \prime} \mathrm{S}, 69^{\circ} 58^{\prime} 01.2^{\prime \prime} \mathrm{W}, 2875 \mathrm{~m}$ a.s.1., litter of Corryocactus brevistylus, 5 Oct. 2012, C. Lado 22110 leg. (MA-Fungi 90842); same data as for preceeding, C. Lado 22111 leg. (MA-Fungi 90844); same data as for preceeding, twig of an unidentified shrub, $C$. Lado 22113 leg. (MA-Fungi 90847); same data as for preceeding, litter of Haageocereus sp., C. Lado 22114 leg. (MA-Fungi 90848); same data as for preceeding, C. Lado 22115 leg. (MA-Fungi 90850); same data as for preceeding, litter of Cumulopuntia corotilla, C. Lado 22116 leg. (MAFungi 90851); same data as for preceeding, C. Lado 22117 leg. (MAFungi 90852); same data as for preceeding, litter of Haageocereus sp., $C$. 
Lado 22119 leg. (MA-Fungi 90857); same data as for preceeding, litter of Browningia candelaris, C. Lado 22120 leg. (MA-Fungi 90858); Pachia, Los Olivares, route PE-40, km 43, $13 \mathrm{~km}$ west of Palca, 17²48'51.5" S, $70^{\circ} 00^{\prime} 33.3^{\prime \prime} \mathrm{W}, 2345 \mathrm{~m}$ a.s.1., litter of Haageocereus sp., 5 Oct. 2012, C. Lado 22122 leg. (MA-Fungi 90860); same data as for preceeding, $C$. Lado 22123 leg. (MA-Fungi 90862); same data as for preceeding, $C$. Lado 22124 leg. (MA-Fungi 90863); same data as for preceeding, litter of Cumulopuntia sphaerica, C. Lado 22127 leg. (MA-Fungi 90866); same data as for preceeding, C. Lado 22128 leg. (MA-Fungi 90867); same data as for preceeding, litter of Browningia candelaris, C. Lado 22132 leg. (MA-Fungi 90873); same data as for preceeding, C. Lado 22136 leg. (MA-Fungi 90877); same data as for preceeding, C. Lado 22137 leg. (MA-Fungi 90878).

Notes.-Without doubt, it is the commonest species of the study area, linked virtually with all the cacti and succulent substrata examined. It has been collected in more than $50 \%$ of the localities sampled, and it was also the commonest species of the arid lands of the coastal desert of Peru (Lado \& al. 2016).

\section{Collaria arcyrionema (Rostaf.) Nann.-Bremek. ex Lado}

Specimens examined.-PERU. Ancash: Huaylas, Caraz, Sucre, route PE-3N, km 665, 08 $56^{\prime} 12.7^{\prime \prime} \mathrm{S}, 77^{\circ} 50^{\prime} 30.8^{\prime \prime} \mathrm{W}, 2044 \mathrm{~m}$ a.s.l., litter of Armatocereus sp., 18 Apr. 2013, C. Lado 22787 leg. (MA-Fungi 91033).

Notes.-In Peru, it was previously reported from the tropical forest of Madre de Dios (Rojas \& al. 2011).

\section{Comatricha ellae Härk. Fig. 3.}

Specimens examined.-PERU. Tacna: Palca, Huanune, route PE-40, km 53, $3 \mathrm{~km}$ west of Palca, 17 $47^{\prime} 17.2^{\prime \prime} \mathrm{S}, 69^{\circ} 58^{\prime} 01.2^{\prime \prime} \mathrm{W}, 2875 \mathrm{~m}$ a.s.1., litter of Haageocereus sp., 5 Oct. 2012, C. Lado 22118 leg. (MA-Fungi 90855).
Notes.-This is the second record of this species from Peru and enlarges its distribution, since previously it was reported from the north, in the arid lands of Piura (Lado \& al. 2016). In the Neotropics it is also known from Argentina, Ecuador, Mexico and Panama (Illana \& al. 2000; Moreno \& al. 2001, 2007, 2015; Lizárraga \& al. 2015b; Lado \& al. 2017; Rojas \& al. 2017). Only one collection of several minute sporocarps, with a columella reaching about $1 / 2$ of the sporotheca, dividing to form the main branches of capillitium, and with the dark capillitium branching and anastomosing (fig. 3a, b) and forming the typical surface net with few free ends (fig. 3c) that matches the original description of Härkönen $(1977,1978)$.

\section{Comatricha laxa Rostaf.}

Specimens examined.-PERU. Ancash: Pallasca, Ancos, route PE-3N, km 104 , Cocabal, $08^{\circ} 29^{\prime} 24.7^{\prime \prime} \mathrm{S}, 78^{\circ} 06^{\prime} 32.5^{\prime \prime} \mathrm{W}, 1605 \mathrm{~m}$ a.s.l., inflorescence of Puya sp., moist chamber culture pH 5.92, 11 Apr. 2013, A. EstradaTorres 13010 leg. (TLXM); same data as for preceeding, moist chamber culture pH 5.31, A. Estrada-Torres 13011 leg. (TLXM); Huaylas, Caraz,

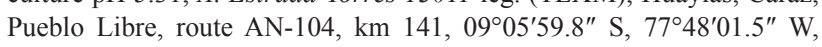
2466 m a.s.l., leaves of Furcraea occidentalis, 20 Apr. 2013, C. Lado 22950 leg. (MA-Fungi 91053). Moquegua: Mariscal Nieto, Ilubaya, route PE-34D, km 44, 1703'15.7" S, 7051'15.4" W, 2630 m a.s.l., litter of Weberbanerocereus weberbaueri, 7 Oct. 2012, C. Lado 22154 leg. (MA-Fungi 90892).

Notes. - It is widely distributed in Peru and was previously reported from Ancash, Arequipa, Ayacucho, Lima, Madre de Dios and Tacna (Rojas \& al. 2011; Rojas \& Stephenson, 2013; Lado \& al. 2016).

\section{Comatricha pulchella (C.Bab.) Rostaf.}

Specimens examined.-PERU. Lima: Yauyos, Yauyos, route PE-24, km $124,12^{\circ} 31^{\prime} 56.7^{\prime \prime} \mathrm{S}, 75^{\circ} 54^{\prime} 52.6^{\prime \prime} \mathrm{W}, 2180 \mathrm{~m}$ a.s.l., litter of Haageocereus decumbens, 1 Oct. 2012, C. Lado 22009 leg. (MA-Fungi 90829).

Notes.-In Peru it was previously reported from Madre de Dios and Ancash by Rojas \& al. (2011) and Lado \& al. (2016), respectively.
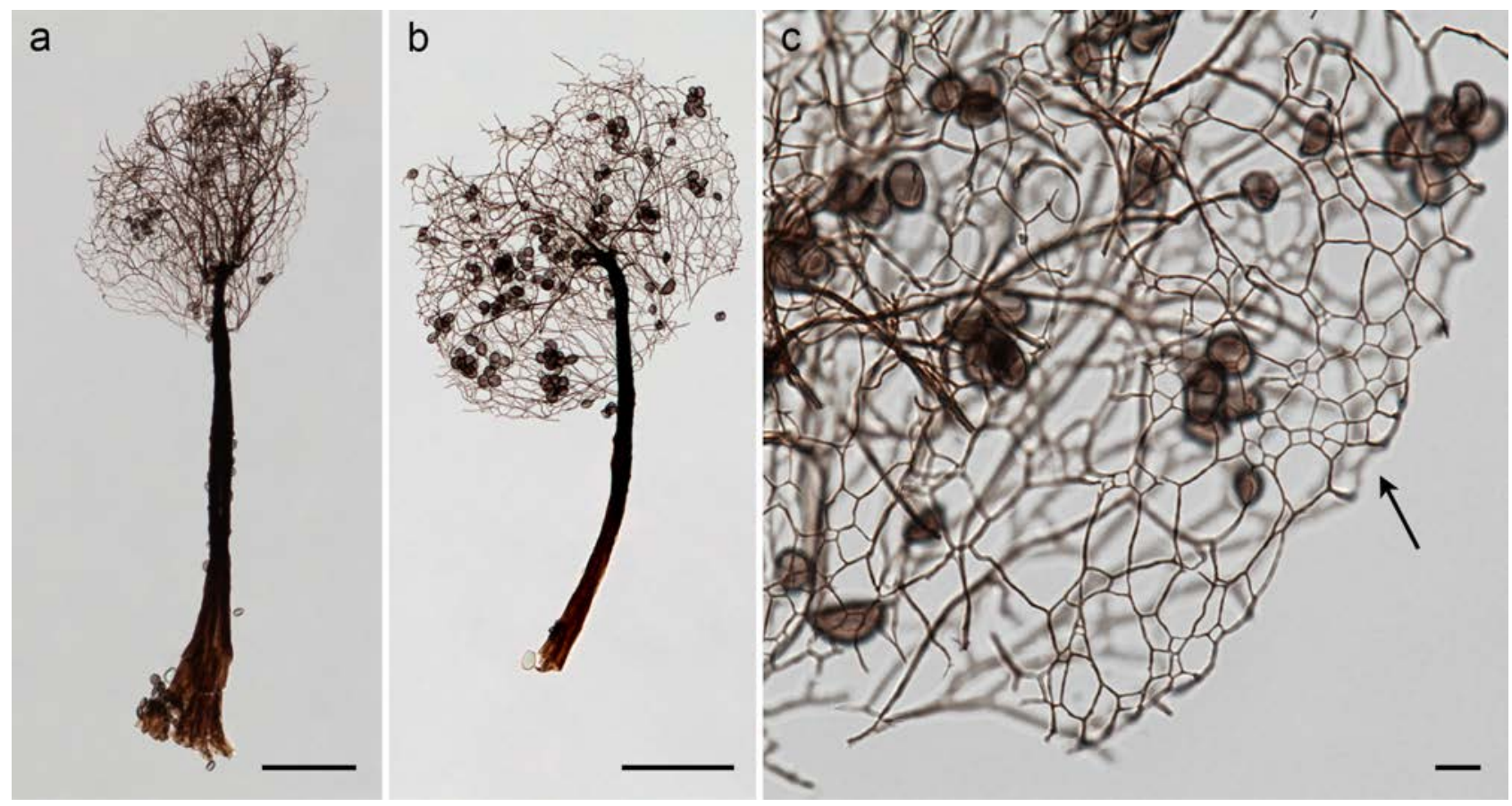

Fig. 3. Comatricha ellae Härk.: a, b, Sporocarps by LM showing the stalk, columella and the capillitium; c, detail of the surface net of the capillitium (arrow) [C. Lado 22118 leg. (MA-Fungi 90855); scale bars: a-b, $100 \mu \mathrm{m} ; \mathrm{c}, 10 \mu \mathrm{m}$ ]. 


\section{Comatricha tenerrima (M.A.Curtis) G.Lister}

Specimens examined.-PERU. La Libertad: Otuzco, Plazapalpa, route PE-10A, km 56, at the junction to Salpo, 0759'19.1" S, 78³9'21.2' W, $1742 \mathrm{~m}$ a.s.l., litter and twigs of herbaceous plant, $12 \mathrm{Apr}$. 2013, C. Lado 22481 leg. (MA-Fungi 90980). Lima: Huarochirí, San Bartolomé, $11^{\circ} 54^{\prime} 33.3^{\prime \prime} \mathrm{S}, 76^{\circ} 31^{\prime} 34.0^{\prime \prime} \mathrm{W}, 1580 \mathrm{~m}$ a.s.l., twigs, moist chamber culture pH 6.4, 22 Sep. 2012, S.L. Stephenson 30123 leg. (UARK); same data as for preceeding, moist chamber culture $\mathrm{pH}$ 6.43, S.L. Stephenson 30126 leg. (UARK); same data as for preceeding, moist chamber culture $\mathrm{pH} 6.43$, S.L. Stephenson 30209 leg. (UARK); Yauyos, Yauyos, route PE-24, km $124,12^{\circ} 31^{\prime} 56.7^{\prime \prime} \mathrm{S}, 7^{\circ} 54^{\prime} 52.6^{\prime \prime} \mathrm{W}, 2180 \mathrm{~m}$ a.s.l., twigs, moist chamber culture pH 6.1, 1 Oct. 2012, S.L. Stephenson 28963 leg. (UARK); same data as for preceeding, moist chamber culture $\mathrm{pH}$ 6.1, S.L. Stephenson 29081 leg. (UARK); same data as for preceeding, moist chamber culture pH 6.06, S.L. Stephenson 29126 leg. (UARK).

Notes.-In Peru it is only known from the tropical forest of Loreto (Wrigley de Basanta \& al. 2008a) and Madre de Dios (Rojas \& Stephenson 2013).

\section{Craterium leucocephalum (Pers. ex J.F.Gmel.) Ditmar}

Specimens examined.-PERU. Cusco: Anta, Limatambo, route PE-3S, km $888,13^{\circ} 29^{\prime} 10^{\prime \prime} \mathrm{S}, 72^{\circ} 27^{\prime} 13^{\prime \prime} \mathrm{W}, 2501 \mathrm{~m}$ a.s.l., leaves and twigs, $18 \mathrm{Apr}$ 2016, C. Lado 24481 leg. (MA-Fungi 91620); same data as for preceeding, C. Lado 24488 leg. (MA-Fungi 91621); same data as for preceeding, C. Lado 24493 leg. (MA-Fungi 91622). Piura: Huancabamba, route PE04E, km 49, Abra Porcuya, 550'28" S, 79²9'22" W, 2005 m a.s.l., leaf litter, 10 May 2014, C. Lado 23478 leg. (MA-Fungi 91098); same data as for preceeding, twigs, C. Lado 23480 leg. (MA-Fungi 91100); same data as for preceeding, C. Lado 23481 leg. (MA-Fungi 91101); same data as for preceeding, C. Lado 23456 leg. (MA-Fungi 91076); same data as for preceeding, leaf litter, C. Lado 23461 leg. (MA-Fungi 91081); same data as for preceeding, twigs, C. Lado 23464 leg. (MA-Fungi 91084); same data as for preceeding, branches, C. Lado 23468 leg. (MA-Fungi 91088); same data as for preceeding, leaf litter, C. Lado 23476 leg. (MA-Fungi 91096).

Notes.-It is a widely distributed species, known in Peru from Ancash, Cajamarca and Madre de Dios (Rojas \& al. 2011; Lado \& al. 2016).

Cribraria spinispora Lado \& D.Wrigley sp. nov. Type: Peru, Moquegua, Mariscal Nieto, Ilubaya, route PE34D, km 44, 1703'15.7" S, 7051'15.4" W, $2630 \mathrm{~m}$ a.s.l., litter of Weberbauerocereus weberbaueri, moist chamber culture pH 8.09, 10 Mar. 2013, D. Wrigley de Basanta 3572 leg. [holo-: MA-Fungi 91751; iso-: dwb]. Fig. $4 \mathrm{a}-\mathrm{d}, \mathrm{f}, \mathrm{g}, \mathrm{i}-\mathrm{n}$.

\section{Mycobank: MB 830426.}

Sporocarps $0.5-0.9 \mathrm{~mm}$ in total height, scatttered, stalked, erect. Sporotheca $0.1-0.3 \mathrm{~mm}$ in diameter, sugblobose, dark purple (224. d. P) to dark violaceous (212. d. V). Hypothallus discoidal, membranous. Stalk $0.35-0.7 \mathrm{~mm}$ in height, cylindrical to slightly attenuated toward the appex, erect to slightly nodding, longitudinally striate, orange brownish (54. br O) to yellowish brown (74. s. y Br) by transmitted light, darker at the base and paler and concolourous with the peridium at the tip. Peridium single, pink grayish (8. gy. Pink-18. 1. gy Pink-32. gy. y Pink) by transmitted light, partially evanescent, remaining in the basal $1 / 3-1 / 2$ as a calyculus, and as a net without nodes or with few fusiform nodes above; calyculus membranous, with radial striations, without perforate margin; net lax mostly isodiametric, threads $2-3 \mu \mathrm{m}$ in diameter, sometimes with few slightly expanded areas but not thickened, with occasional free-ending threads; dehiscence apical by disintegration of the peridium to leave the peridial net. Columella absent. Capillitium absent. Spores 9-11 $\mu \mathrm{m}$ in diameter, free, dark purplish (224. d. P) in mass, pale pink (8. p. Pink-32. gy. y Pink) by transmitted light, slightly angular or polygonal, densely spinulose, the spines in the centre of the polygons by SEM. Calcic granules 1-2 $\mu \mathrm{m}$ in diameter, concentrated in the peridial net and the upper border of the calyculus, dispersed in the rest of the calyculus, pinkish (4. 1. Pink-8. gy. Pink). Plasmodium not observed.

Etymology.-The epithet 'spinispora' refers to the spines present as ornamentation on the spores.

Habitat.-On dead remains and litter of cacti (Weberbauerocereus and Espostoa).

Distribution.-It is known only from the South and Central Peru (Moquegua and Lima regions), in 'cardonal' areas, between 2000 and $2700 \mathrm{~m}$ a.s.1.

Notes.-The principal characters that distinguish this minute species from others in the genus are the larger diameter of the spores, 9-11 $\mu \mathrm{m}$, that are pinkish, angular or polygonal and ornamented with spines, the spines more concentrated in the centre of the polygons, clearly visible by SEM (fig. 4i, j). The peridium is evanesent in the upper part but leaves a mostly isodiametric net, with bands filled with calcic granules (fig. 4g) Occasionally, the bands are slightly flattened or fusiform but do not form well-defined plates or nodes, and have only occasional free ends. The calyculus reaches one third to one half of the diameter of the sporotheca (fig. $4 \mathrm{a}-\mathrm{c}, \mathrm{k}-\mathrm{n}$ ), and the upper border is filled with calcic granules, darker and well-defined (fig. 4g). The colour of the sporotheca is dark purple to dark violaceous. The combination of these characters does not match any described species of Cribraria Pers. and so we describe it here as a new species.

Cribraria confusa Nann.-Bremek. \& Y.Yamam., Cribraria minutissima Schwein. and Cribraria rufa (Roth) Rostaf. have an evanescent peridium that also leaves an isodiametric net, but differ in the size of the spores (6-8 $\mu \mathrm{m}$ in diameter), and the brown colour of the sporotheca (Martin \& Alexopoulos 1969; Nannenga-Bremekamp 1991; NannengaBremekamp \& Yamamoto 1983). Cribraria paucidictyon $\mathrm{Yu} \mathrm{Li}$ also has a peridial network and a size of the sporocarps similar to Cribraria spinispora sp. nov., but differs in the colour of the sporotheca, that is brown to chestnut-brown, and in the size (diameter 6.3-7.5 $\mu \mathrm{m}$ ) and the ornamentation of the spores, illustrated by SEM and defined by Li (2002) as "minutely and densely covered with long warts, with incomplete and faint reticulation combined by long warts". Regarding the colour of the sporotheca the new species resembles Cribraria violacea Rex, Cribraria tecta Hooff and Cribraria purpurea Schrad., but the spores in all three cases are smaller, with a diameter less than $8 \mu \mathrm{m}$. In addition, in Cribraria violacea the colour of the sporotheca is violet (fig. 4h) and the peridial net forms flat plates with many free ends, the spores by SEM, according to the illustration provided by Moreno \& al. (2001), are baculate with small crests instead of spiny. Cribraria tecta is differentiated by the apical peridial plate that remains as a parachute (van Hooff 2009) and the spores by SEM are ornamented with dispersed spines with a broad base. Cribraria purpurea is also distinguished by the larger dimensions of the fruiting bodies (Martin \& Alexopoulos 1969), 1.5-2.5(3) $\mathrm{mm}$ in total height vs. $0.5-0.9 \mathrm{~mm}$ in the new species, as well as the sporotheca, with a diameter $0.6-1 \mathrm{~mm}$ vs. $0.1-0.3 \mathrm{~mm}$ in Cribraria spinispora $\mathrm{sp}$. nov. Cribraria fragilis Lado \& Estrada and Cribraria zonatispora Lado, Mosquera \& Beltrán-Tej. also appear on dead remains of cacti and have fruiting bodies with purplish shades, but the small dimensions of 


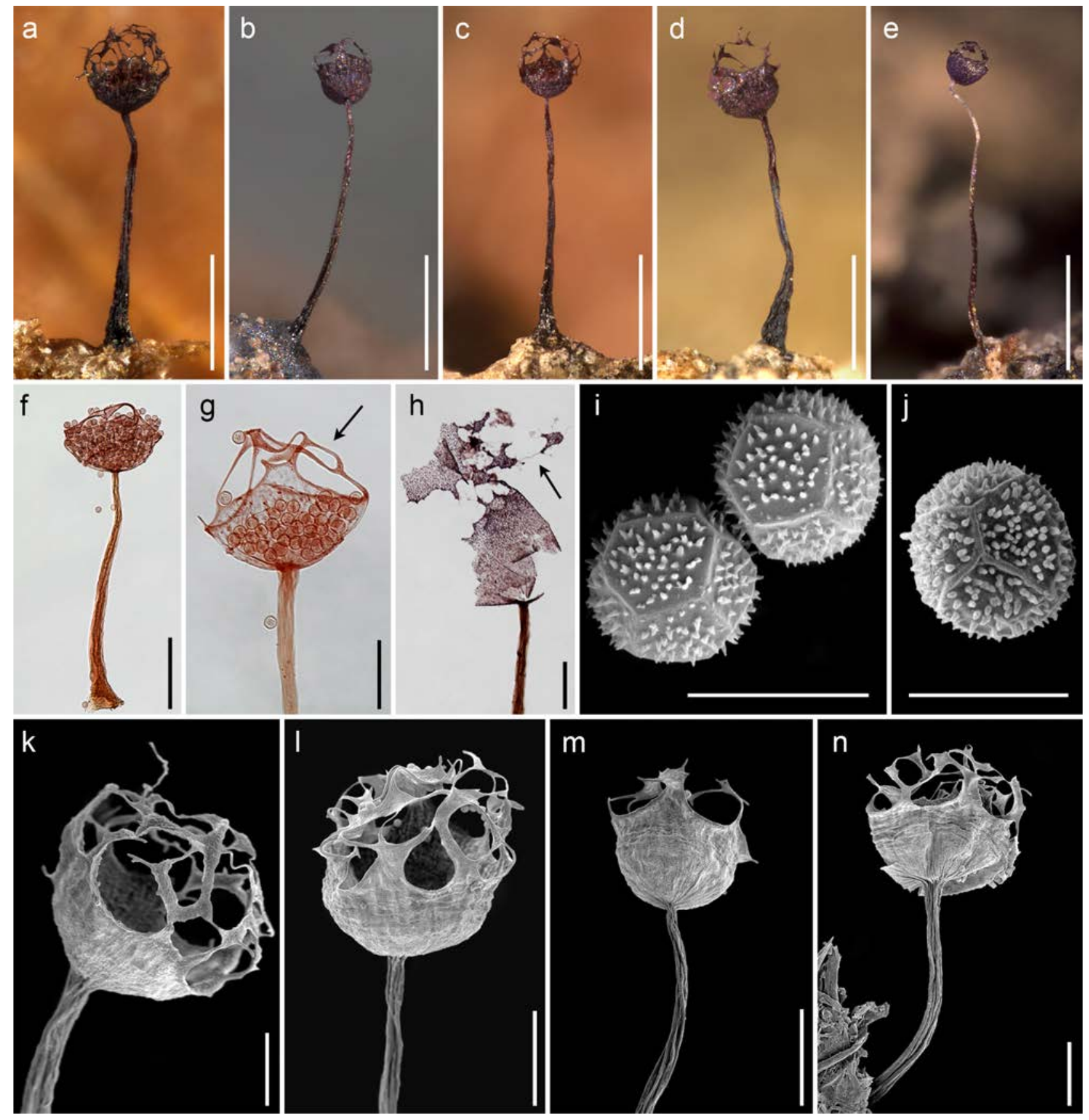

Fig. 4. A-D, F, G, I-N, Cribraria spinispora Lado \& D.Wrigley sp. nov.: a-d, sporocarps; f, sporocarp by TL; $\mathbf{g}$, detail of the sporotheca and isodiametric peridial net (arrow) by TL; $\mathbf{i}, \mathbf{j}$, ornamentation of the spores by SEM; $\mathbf{k}$, details of the calyculus and peridial net of the sporotheca by SEM; $\mathbf{l}-\mathbf{n}$, details of the calyculus and peridial net of the sporotheca by SEM. E, H, Cribraria violacea Rex: e, sporocarp; h, violet sporotheca and peridial plates with free ends by TL. [a-d, k, $D$. Wrigley de Basanta 3572 leg. (dwb, isotype); e, C. Lado 25248 leg. (MA-Fungi 91623); f, C. Lado 22013 leg. (MA-Fungi 90833); g, D. Wrigley de Basanta 3572 leg. (dwb, isotype); h, C. Lado 22482 leg. (MA-Fungi 90981); i, j, l-n, D. Wrigley de Basanta 3574 leg. (dwb); scale bars: a-e, $0.5 \mathrm{~mm}$; f, h, l-n, $100 \mu \mathrm{m} ; \mathrm{g}, \mathrm{k}, 50 \mu \mathrm{m}$; i-j, $10 \mu \mathrm{m}$.] 
the sporotheca (diameter $0.05-0.13 \mathrm{~mm}$ and $0.08-0.2 \mathrm{~mm}$ respectively, instead of 0.1-0.3 $\mathrm{mm}$ in Cribraria spinispora sp. nov.), and the different size and unique shapes of the spores (Lado \& al. 1999; Estrada \& al 2001), differentiate these species. Cribraria lepida Meyl. also has a purple colour of the sporotheca and has been recorded in arid lands of South America (Lado \& al. 2011), but it is distinguished by the larger dimensions of the sporocarps $(2-5 \mathrm{~mm}$ in height), the peridial net with pulvinate nodes, and the smaller and almost smooth spores, (6)7-8 $\mu \mathrm{m}$ in diameter (Martin \& Alexopoulos 1969).

The only known species of Cribraria described with spores with a diameter of 9-11 $\mu \mathrm{m}$ are Cribraria macrospora Nowotny \& H.Neubert, Cribraria microcarpa var. megaspora Shuang L.Chen \& M.Q.Guo and Cribraria stellifera Nowotny \& H.Neubert, but in all these taxa the sporothecae are ochraceous, nut brown or reddish brown, not dark purple or dark violaceous as in Cribraria spinispora sp. nov. Additionally, Cribraria macrospora has larger sporocarps, $2.5-4 \mathrm{~mm}$ in total height, sporotheca with a diameter of $1-1.6 \mathrm{~mm}$, and the peridial net is more dense, intricate, and has free ends (Neubert \& al. 1993). In Cribraria microcarpa var. megaspora and Cribraria stellifera the peridial net is dense and intricate, and has numerous rounded and pulvinate nodes with several free ends (Neubert \& al. 1993; Guo \& Chen 2014).

Cribraria spinispora sp. nov. was collected in the field, where it fruited under natural conditions, and was isolated from moist chamber cultures. The new species seems to be exclusive to the 'cardonal'. In all the cases, the new species was growing on dead remains of Peruvian columna cacti, Espostoa lanata (Kunth) Britton \& Rose and Weberbauerocereus weberbaueri (K.Schum. ex Vaupel) Backeb., in extremely arid lands and can be closely linked to these substrates, since it has not been observed in the rest of the many cacti analyzed in this and other studies. The collections are from two different regions in Peru and from different dates and substrates, the characters are stable and common in all the collections. This is the third small succulenticolous species of Cribraria developing only on cacti, like Cribraria zonatispora and Cribraria fragilis, suggesting that the microhabitat in these substrates may have favoured diversification in the group.

Other specimens examined.-PERU. Lima: Yauyos, Yauyos, route

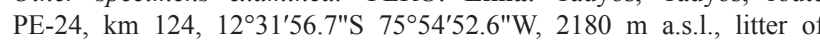
Espostoa lanata, 1 Oct. 2012, C. Lado 22013 leg. (MA-Fungi 90833). Moquegua: Mariscal Nieto, Ilubaya, route PE-34D, km 44, 1703'15.7" S, 70 $51^{\prime} 15.4^{\prime \prime} \mathrm{W}, 2630 \mathrm{~m}$ a.s.1., litter of Weberbanerocereus weberbaneri, moist chamber culture pH 8.28, 23 Mar. 2013, D. Wrigley de Basanta 3573 leg. (dwb); same data as for preceeding, moist chamber culture $\mathrm{pH}$ 7.95, 22 Mar. 2013, D. Wrigley de Basanta 3574 leg. (dwb).

\section{Cribraria violacea Rex. Fig. 4e, h.}

Specimens examined.-PERU. La Libertad: Otuzco, Plazapalpa, route PE-10A, km 56, at the junction to Salpo, 07059'19.1" S, 78 39'21.2" W, $1742 \mathrm{~m}$ a.s.1., litter and twigs of herbaceous plant, 12 Apr. 2013, C. Lado 22482 leg. (MA-Fungi 90981). Huancavelica: Tayacaja, route PE-3S, $\mathrm{km} 198$, Izcuchaca, $7 \mathrm{~km}$ south of Izcuchaca, $12^{\circ} 31^{\prime} 17^{\prime \prime} \mathrm{S}, 74^{\circ} 56^{\prime} 50^{\prime \prime} \mathrm{W}$ 2840 m a.s.1., leaves of Puya sp., 25 Apr. 2017, C. Lado 25248 leg. (MAFungi 91623).

Notes.-A minute species reported previously in Peru from Cajamarca and Madre de Dios (Rojas \& al. 2011; Rojas \& Stephenson 2013; Lado \& al. 2016). The long stalked sporocarps, the violet colour of the sporotheca and the peridial net with plates and many slender free end (fig. $4 \mathrm{e}, \mathrm{h}$ ) characterized this species.

\section{Diachea leucopodia (Bull.) Rostaf.}

Specimens examined.-PERU. La Libertad: Otuzco, Plazapalpa, route PE-10A, km 56, at the junction to Salpo, 0759'19.1" S, 78 39'21.2" W, $1742 \mathrm{~m}$ a.s.1., litter and twigs of herbaceous plant, 12 Apr. 2013, C. Lado 22483 leg. (MA-Fungi 90982); same data as for preceeding, C. Lado 22490 leg. (MA-Fungi 90990).
Notes.-In Peru it was previously reported only by Rojas \& al. (2011) and Rojas \& Stephenson (2013) from the tropical forest of Madre de Dios.

\section{Diderma acanthosporum Estrada \& Lado. Fig. 5a-d.}

Specimens examined.-PERU. La Libertad: Otuzco, Plazapalpa, route PE-10A, km 56, at the junction to Salpo, 0759'19.1" S, 78³9'21.2" W, $1742 \mathrm{~m}$ a.s.1., litter and twigs of herbaceous plant, 12 Apr. 2013, C. Lado 22428 leg. (MA-Fungi 90923); same data as for preceeding, C. Lado 22493 leg. (MA-Fungi 90993)

Notes.-It is the second record of this species from South America, which was previously reported from Ancash (Peru) by Lado \& al. (2016). In the Neotropics it is only known from Mexico, where the species was described. The distinctive characters of this specimens are the crowded and stalked sporocarps (fig. 5a-d), the hemisphaeric, depressed sporotheca, angular from mutual pressure (fig. 5a, b), the stalk that is calcareous, short and wide (fig. 5d), giving the appearance of being an extension of the hypothallus, the double peridium, the outer layer thick, crustose, calcareous, smooth, and with an irregular to almost circumscissile dehiscence. The capillitium is branched and anastomosed forming a net (fig. 5c), and the typical large spores, with a diameter of 16 $20 \mu \mathrm{m}$, ornamented with few, prominent, sharp spines, of almost $3 \mu \mathrm{m}$ in length. All these features agree with the original description of the species provided by Estrada-Torres \& al. (2001)

\section{Diderma effusum (Schwein.) Morgan}

Specimens examined.-PERU. Cusco: Anta, Limatambo, route PE-3S,

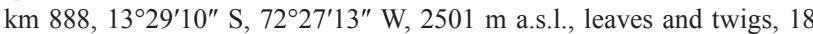
Apr. 2016, C. Lado 24490 leg. (MA-Fungi 91624). La Libertad: Otuzco, Plazapalpa, route PE-10A, km 56, at the junction to Salpo, 0759'19.1" S, $78^{\circ} 39^{\prime} 21.2^{\prime \prime} \mathrm{W}, 1742 \mathrm{~m}$ a.s.1., litter of herbaceous plant, twigs and living leaves, 12 Apr. 2013, C. Lado 22436 leg. (MA-Fungi 90932); same data as for preceeding, leaves of Puya sp., C. Lado 22476 leg. (MA-Fungi 90975); same data as for preceeding, litter and twigs of herbaceous plant, C. Lado 22480 leg. (MA-Fungi 90979); same data as for preceeding, C. Lado 22484 leg. (MA-Fungi 90983); same data as for preceeding, $C$. Lado 22485 leg. (MA-Fungi 90984); same data as for preceeding, $C$. Lado 22488 leg. (MA-Fungi 90987); same data as for preceeding, $C$. Lado 22491 leg. (MA-Fungi 90991). Lima: Canta, $2 \mathrm{~km}$ south of Canta, $11^{\circ} 28^{\prime} 30^{\prime \prime} \mathrm{S}, 76^{\circ} 37^{\prime} 45^{\prime \prime} \mathrm{W}, 2700 \mathrm{~m}$ a.s.1., cladode of Opuntia sp., 18 May 2014, C. Lado 23625 leg. (MA-Fungi 91127).

Notes.-In Peru it was only known from Cajamarca and Madre de Dios (Rojas \& al. 2011; Rojas \& Stephenson, 2013; Lado \& al. 2016).

\section{* Diderma globosum Pers.}

Specimens examined.-PERU. Ancash: Pallasca, Ancos, route PE-3N, km 104, Cocabal, 08 29'24.7" S, 78 06'32.5" W, 1605 m a.s.l., leaves of Puya sp., 11 Apr. 2013, C. Lado 22402 leg. (MA-Fungi 90907); Huari, $21 \mathrm{~km}$ from Huari towards San Marcos, 92 $8^{\prime} 02^{\prime \prime}$ S, $77^{\circ} 08^{\prime} 37^{\prime \prime} \mathrm{W}, 2827 \mathrm{~m}$ a.s.l., leaves of Baccharis latifolia, 21 May 2014, C. Lado 23723 leg. (MA-Fungi 91153); same data as for preceeding, C. Lado 23724 leg. (MA-Fungi 91154); same data as for preceeding, C. Lado $23725 \mathrm{leg}$. (MA-Fungi 91155); same data as for preceeding, C. Lado 23726 leg. (MA-Fungi 91156). Cusco: Anta, Limatambo, route PE-3S, km 888 , $13^{\circ} 29^{\prime} 10^{\prime \prime} \mathrm{S}, 72^{\circ} 27^{\prime} 13^{\prime \prime} \mathrm{W}, 2501 \mathrm{~m}$ a.s.l., leaves and twigs, $18 \mathrm{Apr} .2016$, C. Lado 24487 leg. (MA-Fungi 91625); same data as for preceeding, $C$. Lado 24489 leg. (MA-Fungi 91626); same data as for preceeding, $C$. Lado 24491 leg. (MA-Fungi 91627); same data as for preceeding, C. Lado 24494 leg. (MA-Fungi 91628); same data as for preceeding, leaf of Furcraea andina, C. Lado 24501 leg. (MA-Fungi 91629).

Notes.-This species has only been reported previously from Argentina, Costa Rica, Ecuador and Venezuela. Farr (1976), in her monograph of Myxomycetes from the Neotropics, also reported a collection from Peru preserved at BPI herbarium, but in a search of the Fungal database of this herbarium no specimens from Peru were found. Several of our specimens 
agree with the commented by Farr (1976: 205) from the Venezuelan Andes, since the capillitium is elastic and the peridium, in the basal zone, where it covers the columella, is brown instead of white.

\section{Diderma hemisphaericum (Bull.) Hornem.}

Specimens examined.-PERU. Ancash: Bolognesi, Cajacay, route PE-16, $\mathrm{km} 96,10^{\circ} 08^{\prime} 03.2^{\prime \prime S} 77^{\circ} 24^{\prime} 03.4^{\prime \prime} \mathrm{W}, 2935 \mathrm{~m}$ a.s.l., litter of herbaceous plant, 24 Apr. 2013, C. Lado 23170 leg. (MA-Fungi 91059); Bolognesi,
Raquia, route PE-16, km 78,600, 1009'08.0" S, 77²8'45.2" W, 1974 m a.s.1., leaves of Puya ferruginea, 24 Apr. 2013, C. Lado 23178 leg. (MAFungi 91066). Cajamarca: Cajamarca, San Juan, route PE-08, km 133, Puente San Juan, $07^{\circ} 16^{\prime} 44.2^{\prime \prime}$ S, 78³1'47.3" W, 1915 m a.s.1., bryophytes ,15 Apr. 2013, C. Lado 22604 leg. (MA-Fungi 91001). Cusco: Anta, Limatambo, route PE-3S, km 888, 13²9'10" S, 72²7'13" W, $2501 \mathrm{~m}$ a.s.1., leaves and twigs, 18 Apr. 2016, C. Lado 24482 leg. (MA-Fungi 91630); same data as for preceeding, C. Lado 24486 leg. (MA-Fungi 91631); same data as for preceeding, C. Lado 24492 leg. (MA-Fungi
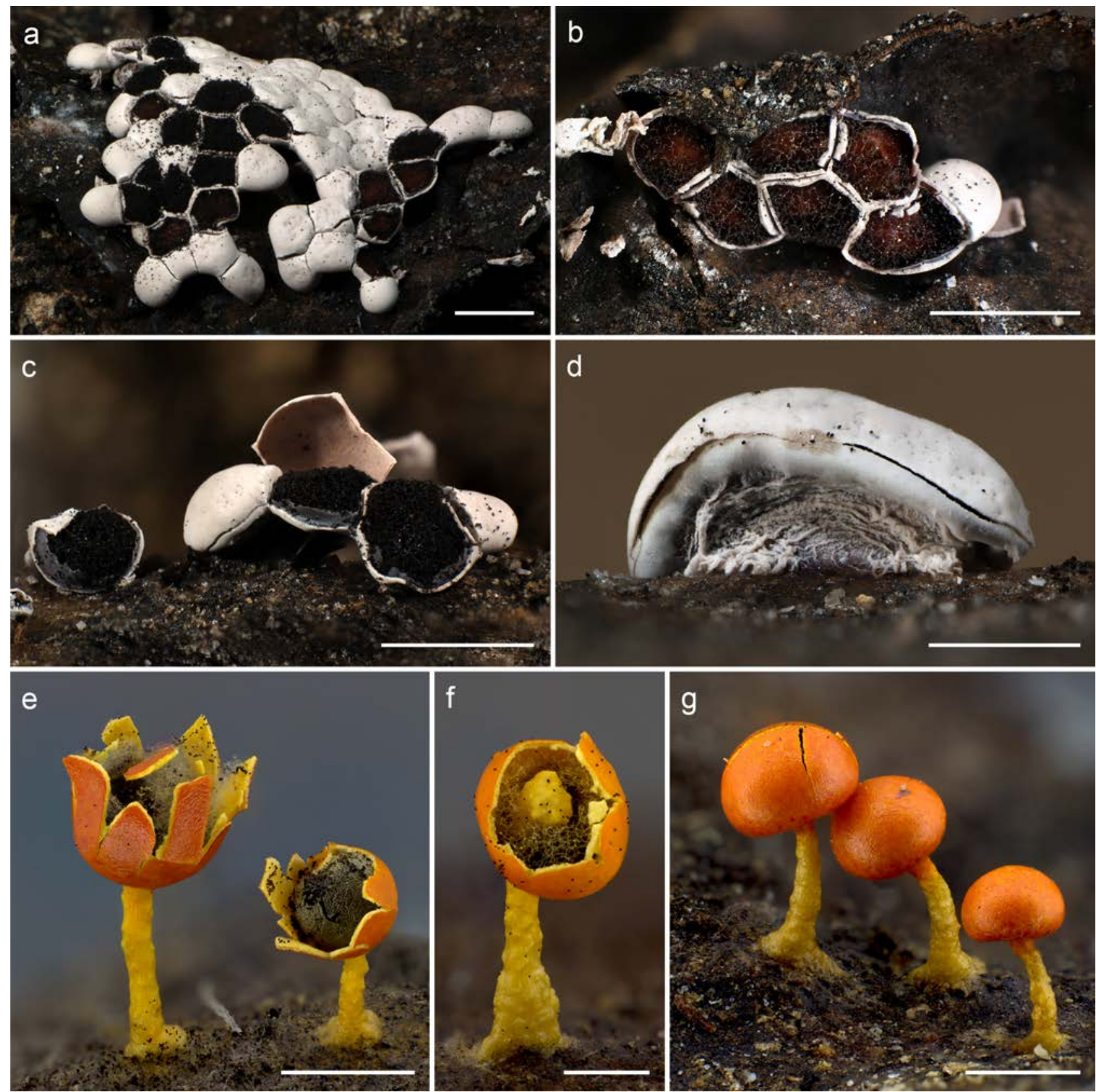

Fig. 5. A-D, Diderma acanthosporum Estrada \& Lado: a, group of sporocarps; b, dehisced sporocarps showing the capillitium; c, details of sporocarps showing the dehiscence and the three layers of the peridium; d, sporocarp showing the line of dehiscence and the rough stalk. $\mathbf{E}-\mathbf{G}$, Diderma miniatum Nann.-Bremek.: e, dehisced sporocarps; f, sporocarp showing the prominent columella and the netted capillitium; g, group of stalked sporocarps [a-d, C. Lado 22493 leg. (MA-Fungi 90993); e-g, C. Lado 24483 leg. (MA-Fungi 91637); scale bars: a-c, e, g, 1 mm; d, f, 0.5 mm]. 
91632); same data as for preceeding, C. Lado 24496 leg. (MA-Fungi 91633); same data as for preceeding, leaf of Furcraea andina, C. Lado 24502 leg. (MA-Fungi 91634); same data as for preceeding, C. Lado 24504 leg. (MA-Fungi 91635); same data as for preceeding, leaf litter, $C$. Lado 24507 leg. (MA-Fungi 91636). La Libertad: Otuzco, Otuzco, route PE-10A, km 70, near the junction to Otuzco and Agalpampa, 07 $55^{\prime} 40.5^{\prime \prime}$ S, 78³4'43.6" W, 2525 m a.s.1., litter of Tillandsia sp., 12 Apr. 2013 C. Lado 22423 leg. leg. (MA-Fungi 90916); Otuzco, Plazapalpa, route PE-10A, km 56, at the junction to Salpo, 07 59'19.1" S, 78³9'21.2' W, 1742 m a.s.l., leaves of Puya sp., 12 Apr. 2013, C. Lado 22457 leg. (MA-Fungi 90955); same data as for preceeding, C. Lado $22458 \mathrm{leg}$. (MA-Fungi 90956); same data as for preceeding, C. Lado $22463 \mathrm{leg}$ (MA-Fungi 90961); same data as for preceeding, C. Lado $22466 \mathrm{leg}$. (MA-Fungi 90964); same data as for preceeding, C. Lado 22467 leg (MA-Fungi 90966); same data as for preceeding, C. Lado $22468 \mathrm{leg}$ (MA-Fungi 90968); same data as for preceeding, C. Lado $22475 \mathrm{leg}$ (MA-Fungi 90974); same data as for preceeding, litter and twigs of herbaceous plant, C. Lado 22489 leg. (MA-Fungi 90988).

Notes.-In Peru it was reported from Ancash, Cajamarca, Madre de Dios and Loreto (Wrigley de Basanta \& al. 2008a; Rojas \& Stephenson 2013; Lado \& al. 2016).

\section{* Diderma miniatum Nann.-Bremek. Fig. 5e-g.}

Specimens examined.-PERU. Cusco: Anta, Limatambo, route PE-3S,

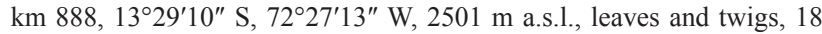
Apr. 2016, C. Lado 24483 leg. (MA-Fungi 91637); same data as for preceeding, leaf litter, C. Lado 24508 leg. (MA-Fungi 91638).

Notes.-In the Neotropics this species is only known from Ecuador, Mexico and Venezuela. The collections of Peru agree with the original description provided by Nannenga-Bremekamp (1989) from the specimen from Ecuador. The most distinctive features of this species is the orange colour of the sporotheca (fig. 5e-g), yellowish inside in opened sporocarps, the prominent and calcareous columella (fig. $5 \mathrm{~g}$ ), the yellowish stalk filled with crystalline lime nodules, and the triple peridium with a dehiscence from the apex into several lobes (fig. 5e).

\section{* Diderma spumarioides (Fr. \& Palmquist) Fr.}

Specimens examined.-PERU. Cusco: Anta, Limatambo, route PE-3S, km $888,13^{\circ} 29^{\prime} 10^{\prime \prime} \mathrm{S}, 7^{\circ} 27^{\prime} 13^{\prime \prime} \mathrm{W}, 2501 \mathrm{~m}$ a.s.l., leaves and twigs, $18 \mathrm{Apr}$ 2016, C. Lado 24479 leg. (MA-Fungi 91639); same data as for preceeding, C. Lado 24484 leg. (MA-Fungi 91640); same data as for preceeding, $C$. Lado 24485 leg. (MA-Fungi 91641); same data as for preceeding, $C$. Lado 24495 leg. (MA-Fungi 91642); same data as for preceeding, leaf of Furcraea andina, C. Lado 24498 leg. (MA-Fungi 91643); same data as for preceeding, C. Lado 24500 leg. (MA-Fungi 91644); same data as for preceeding, C. Lado 24502 leg. (MA-Fungi 91645). Huancavelica: Tayacaja, route PE-3S, km 198, Izcuchaca, $7 \mathrm{~km}$ south of Izcuchaca, $12^{\circ} 31^{\prime} 17^{\prime \prime}$ S, $74^{\circ} 56^{\prime} 50^{\prime \prime}$ W, 2840 m a.s.1., 25 Apr. 2017, C. Lado 25253 leg. (MA-Fungi 91646); same data as for preceeding, C. Lado $25254 \mathrm{leg}$. (MA-Fungi 91647).

Notes.-It is a widely distributed species throughout the Neotropics, but not reported from Peru. The taxonomic characters of our collections exhibit considerable variation and it is difficult to establish satisfactory diagnostic criteria. In the specimen C. Lado 24479 leg., for example, the columella is white very prominent and almost cylindrical, the capillitial threads are expanded in zig-zag, and the spores has a diameter of 9-10 $\mu \mathrm{m}$, and are ornamented with prominent and dispersed spines. In other Peruvian collections, some of these features are not evident. Farr (1976), in her monograph of Myxomycetes of Flora Neotropica also pointed out the variability of the specimens examined and provides a broader description. We follow her criteria and have included all these collections under the same binomen.

\section{Didymium anellus Morgan}

Specimens examined.-PERU. La Libertad: Otuzco, Plazapalpa, route PE-10A, km 56, at the junction to Salpo, 0759'19.1" S, 78³9'21.2" W, $1742 \mathrm{~m}$ a.s.1., litter and twigs of herbaceous plant, 12 Apr. 2013, C. Lado 22442 leg. (MA-Fungi 90938). Piura: Huancabamba, route PE-04E, km 49, Abra Porcuya, 5 $50^{\prime} 28^{\prime \prime}$ S, 79²9'22" W, 2005 m a.s.l., leaf of Zea mays, 10 May 2014, C. Lado 23500 leg. (MA-Fungi 91120).

Notes.-In Peru this species has been reported from Arequipa, La Libertad, Lima and Tumbes (Lado \& al. 2016), linked always to arid areas. The specimen C. Lado 22442 leg. has only five stipitate sporocarps, and does not match the description provided by Farr (1976) for specimens from the Neotropics, but it is placed in this species tentatively because of the short and black stalks of the sporocarps, the colourless peridium, and the bigger spores, with a diameter of $10-12 \mu \mathrm{m}$, that are pale brown and with groups of darker warts. This collection resembles Didymium clavus (Alb. \& Schwein.) Rabenh. and Didymium melanospermum (Pers.) T.Macbr., but in these species the peridium is areolate or brown. Also, the spores in Didymium clavus are smaller (6-7 $\mu \mathrm{m}$ in diameter), and in Didymium melanospermum are bigger (10-14 $\mu \mathrm{m}$ in diameter). In the specimen $C$. Lado 23500 leg., the dehiscence is clearly circumcissile.

\section{Didymium clavus (Alb. \& Schwein.) Rabenh.}

Specimens examined.-PERU. Ancash: Huari, $21 \mathrm{~km}$ from Huari towards San Marcos, $9^{\circ} 28^{\prime} 02^{\prime \prime}$ S, 77 $07^{\prime} 37^{\prime \prime}$ W, $2827 \mathrm{~m}$ a.s.1., leaves of Baccharis latifolia, 21 May 2014, C. Lado 23727 leg. (MA-Fungi 91157). Apurimac: Abancay, Auquibamba, route PE-3S, km 765, 13 ${ }^{\circ} 40^{\prime} 58^{\prime \prime} \mathrm{S}$, 72 57'26" W, $2265 \mathrm{~m}$ a.s.1., cane leaf, 19 Apr. 2016, C. Lado 24539 leg. (MA-Fungi 91650). Arequipa: Arequipa, Yarabamba, Quequeña, $16^{\circ} 33^{\prime} 10^{\prime \prime} \mathrm{S}, 71^{\circ} 27^{\prime} 32^{\prime \prime} \mathrm{W}, 2510 \mathrm{~m}$ a.s.l., leaves of Puya cylindrica, 11 Apr. 2016, C. Lado 24210 leg. (MA-Fungi 91648). Cusco: Anta, Limatambo, route PE-3S, km 888, 13⒉ $9^{\prime} 10^{\prime \prime} \mathrm{S}, 72^{\circ} 27^{\prime} 13^{\prime \prime} \mathrm{W}, 2501 \mathrm{~m}$ a.s.1., leaves and twigs, 18 Apr. 2016, C. Lado 24480 leg. (MA-Fungi 91649). Huancavelica: Angaraes, route PE-26B, km 158, $4 \mathrm{~km}$ west of Laramate, $13^{\circ} 01^{\prime} 48^{\prime \prime}$ S, 742 $23^{\prime} 48^{\prime \prime}$ W, 2890 m a.s.1., wood of Acacia sp., 22 Apr. 2017, C. Lado 25044 leg. (MA-Fungi 91651).

Notes.-In Peru it was reported from Ayacucho and Madre de Dios (Rojas \& al. 2011; Rojas \& Stephenson 2013; Lado \& al. 2016).

\section{Didymium difforme (Pers.) Gray}

Specimens examined.-PERU. Arequipa: Arequipa, Yarabamba, Quequeña, 16 $6^{\circ} 33^{\prime} 10^{\prime \prime} \mathrm{S}, 71^{\circ} 27^{\prime} 32^{\prime \prime} \mathrm{W}, 2510 \mathrm{~m}$ a.s.l., leaves of Puya cylindrica, 11 Apr. 2016, C. Lado 24216 leg. (MA-Fungi 91652). Lima:

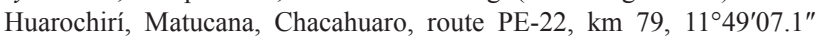
S, 76 $21^{\prime} 37.3^{\prime \prime} \mathrm{W}, 2515 \mathrm{~m}$ a.s.1., aerial litter, moist chamber culture $\mathrm{pH}$ 6.17, 23 Sep. 2012, S.L. Stephenson 28362 leg. (UARK); same data as for preceeding, moist chamber culture $\mathrm{pH}$ 6.37, S.L. Stephenson 28366 leg. (UARK); Yauyos, Yauyos, Auco, route PE-24, km 110, 12³6'45.3"S $75^{\circ} 58^{\prime} 31.6^{\prime \prime} \mathrm{W}, 1775 \mathrm{~m}$ a.s.l., twigs, moist chamber culture $\mathrm{pH} 5.31,1$ Oct. 2012, S.L. Stephenson 28913 leg. (UARK).

Notes.-It is widely distributed throughout the Neotropics as well as Peru (Ancash, Ica, Lima, Madre de Dios, Moquegua and Tacna), usually linked to litter and dead leaves (Rojas \& al. 2011; Rojas \& Stephenson 2013; Lado \& al. 2016).

\section{* Didymium floccosum G.W.Martin, K.S.Thind \& Rehill}

Specimens examined.-PERU. Piura: Huancabamba, route PE-04E,

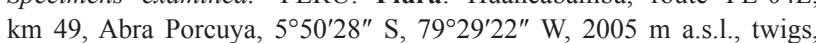
10 May 2014, C. Lado 23453 leg. (MA-Fungi 91073); same data as for preceeding, C. Lado 23467 leg. (MA-Fungi 91087); same data as for preceeding, leaf litter and twigs, C. Lado 23479 leg. (MA-Fungi 91099). 
Notes.-In the Neotropics this species is known from Argentina, Costa Rica, Ecuador, Jamaica, Mexico and Venezuela, but these are the first records for Peru. The Peruvian specimens are characterized by their yellow stalks, filled with lime, the areolate peridium, the clavate columella, the dark spores with a diameter of $8-10 \mu \mathrm{m}$, warted and with goups of darker warts. All these features agree with the description provided by Farr (1976) for the Neotropical specimens.

\section{* Didymium infundibuliforme D.Wrigley, Lado \& Estrada}

Specimens examined.-PERU. Lima: Yauyos, Calachota, route PE-24

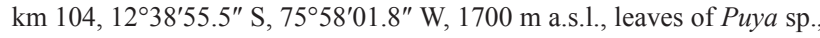
1 Oct. 2012, C. Lado 22018 leg. (MA-Fungi 90838); same data as for preceeding, C. Lado 22020 leg. (MA-Fungi 90840).

Notes.-This species, described originally from arid lands of Argentina and Chile, is now reported from Peru, on the same substrate as the type collection, the leaves of the bromeliad Puya sp. The Peruvian specimens agree with the original description of Wrigley de Basanta \& al. (2009).

\section{* Didymium karstensii Nann.-Bremek.}

Specimens examined.-PERU. Ancash: Bolognesi, Raquia, route PE-16, $\mathrm{km} 78.600,10^{\circ} 09^{\prime} 08.0^{\prime \prime} \mathrm{S}, 7^{\circ} 28^{\prime} 45.2^{\prime \prime} \mathrm{W}, 1974 \mathrm{~m}$ a.s.1., leaves of Puya ferruginea, 24 Apr. 2013, C. Lado 23177 leg. (MA-Fungi 91065).

Notes.-This is the first record of the species from the continental Neotropics, although previously reported from the Galapagos Islands (Ecuador) by Eliasson \& Nannenga-Bremekamp (1983).

\section{* Didymium melanospermum (Pers.) T.Macbr.}

Specimens examined.-PERU. Piura: Huancabamba, route PE-04E, km

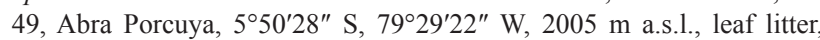
10 May 2014, C. Lado 23490 leg. (MA-Fungi 91110); same data as for preceeding, C. Lado 23491 leg. (MA-Fungi 91111); same data as for preceeding, C. Lado 23492 leg. (MA-Fungi 91112); same data as for preceeding, C. Lado 23494 leg. (MA-Fungi 91114); same data as for preceeding, C. Lado 23495 leg. (MA-Fungi 91115); same data as for preceeding, C. Lado 23498 a leg. (MA-Fungi 90494); same data as for preceeding, C. Lado 23499 leg. (MA-Fungi 91119).

Notes.-It is a widely distributed species in the Neotropics, but has not been reported previously from Peru. All the collections are uniform in therir features, the peridium has poorly marked areoles, the stalks are scantily developed, blackish but occasionally whitish, the columella is small, flattened, as a basal disc, ochraceous-whitish, and the spores are dark brown and uniformely warted, with a diameter of 10-12 $\mu \mathrm{m}$. Macroscopically our specimens resemble the small forms of the variable species Didymium squamulosum.

\section{* Didymium nigripes (Link) Fr.}

Specimens examined.-PERU. Ancash: Huari, $21 \mathrm{~km}$ from Huari towards San Marcos, $9^{\circ} 28^{\prime} 02^{\prime \prime}$ S, $77^{\circ} 08^{\prime} 37^{\prime \prime}$ W, $2827 \mathrm{~m}$ a.s.1., branch of Baccharis latifolia, 21 May 2014, C. Lado 23725 leg. (MA-Fungi 91752).

Notes.-It is widely distributed in the Neotropics but has not been reported previously from Peru. It was found in the upper limit of the 'cardonal' (2800 $\mathrm{m}$ a.s.1.), growing on the shrubs.

\section{Didymium nigrisporum Nann.-Bremek., K.G.Mukerji \&} Pasricha

Specimens examined.-PERU. Ancash: Bolognesi, Raquia, route PE-16,

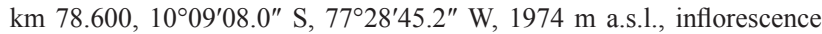
of Tillandsia purpurea, moist chamber culture pH 7.75, 24 Apr. 2013, A. Estrada-Torres 13025 leg. (TLXM). Lima: Huarochirí, San Bartolomé, $11^{\circ} 54^{\prime} 33.3^{\prime \prime} \mathrm{S}, 76^{\circ} 31^{\prime} 34.0^{\prime \prime} \mathrm{W}, 1580 \mathrm{~m}$ a.s.1., ground litter, moist chamber culture pH 5.49, 22 Sep. 2012, S.L. Stephenson 30097 leg. (UARK); same data as for preceeding, moist chamber culture pH 5.3, S.L. Stephenson 30098 leg. (UARK); Huarochirí, Matucana, Chacahuaro, route PE-

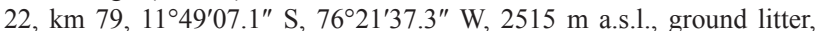
moist chamber culture $\mathrm{pH}$ 6.0, 23 Sep. 2012, S.L. Stephenson 28855 leg. (UARK); same data as for preceeding, moist chamber culture $\mathrm{pH}$ 6.1, S.L. Stephenson 28912 leg. (UARK); same data as for preceeding, moist chamber culture pH 6.1, S.L. Stephenson 29088 leg. (UARK); Yauyos, Yauyos, route PE-24, km 124, 12³1'56.7" S, 7554'52.6" W, $2180 \mathrm{~m}$ a.s.1., ground litter, moist chamber culture pH 6.9, 1 Oct. 2012, S.L. Stephenson 29168 leg. (UARK); same data as for preceeding, moist chamber culture pH 7.14, S.L. Stephenson 29174 leg. (UARK); same data as for preceeding, twigs, moist chamber culture $\mathrm{pH} 6.89$, S.L. Stephenson 29186 leg. (UARK); Yauyos, Calachota, route PE-24, km $104,12^{\circ} 38^{\prime} 55.5^{\prime \prime} \mathrm{S}, 75^{\circ} 58^{\prime} 01.8^{\prime \prime} \mathrm{W}, 1700 \mathrm{~m}$ a.s.l., inflorescence of Puya sp., moist chamber culture pH 8.01, 1 Oct. 2012, A. Estrada-Torres 12241 leg. (TLXM). Piura: Huancabamba, route PE-04E, km 49, Abra Porcuya, $5^{\circ} 50^{\prime 2} 8^{\prime \prime} \mathrm{S}, 79^{\circ} 29^{\prime} 22^{\prime \prime} \mathrm{W}, 2005 \mathrm{~m}$ a.s.1., branches, 10 May 2014, C. Lado 23470 leg. (MA-Fungi 91090); same data as for preceeding, C. Lado 23471 leg. (MA-Fungi 91091); same data as for preceeding, leaf litter, C. Lado 23477 leg. (MA-Fungi 91097); same data as for preceeding, C. Lado 23482 leg. (MA-Fungi 91102); same data as for preceeding, $C$. Lado 23485 leg. (MA-Fungi 91105); same data as for preceeding, C. Lado 23486 leg. (MA-Fungi 91106); same data as for preceeding, leaf litter, C. Lado 23487 leg. (MA-Fungi 91107); same data as for preceeding, C. Lado 23496 leg. (MA-Fungi 91116); same data as for preceeding, C. Lado 23497 leg. (MA-Fungi 91117); same data as for preceeding, twigs, $C$. Lado 23488 leg. (MA-Fungi 91108).

Notes.-This species, originally described from India (NannengaBremekamp \& al. 1984), is widely distributed in the arid lands of Peru (Lado \& al. 2016).

\section{Didymium quitense (Pat.) Torrend}

Specimens examined.-PERU. La Libertad: Otuzco, Plazapalpa, route PE-10A, km 56, at the junction to Salpo, 0759'19.1" S, 78³9'21.2" W, 1742 m a.s.1., leaves of Puya sp., 12 Apr. 2013, C. Lado 22459 leg. (MA-Fungi 90957). Lima: Huarochirí, San Bartolomé, 1154'33.3" S, $76^{\circ} 31^{\prime} 34.0^{\prime \prime} \mathrm{W}, 1580 \mathrm{~m}$ a.s.1., litter of Haageocereus sp., 22 Sep. 2012, C. Lado 21705 leg. (MA-Fungi 90764). Piura: Huancabamba, route PE04E, km 49, Abra Porcuya, 550'28" S, 79²9'22" W, 2005 m a.s.1., leaf litter, 10 May 2014, C. Lado 23489 leg. (MA-Fungi 91109).

Notes.-The distribution of this species in Peru is enlarged considerably with these collections, since it was limited to Piura in the north of the country (Lado \& al. 2016), and now it is also known from La Libertad and Lima.

\section{Didymium squamulosum (Alb. \& Schwein.) Fr. \& Palmquist}

Specimens examined.-PERU. Arequipa: Arequipa, Yarabamba,

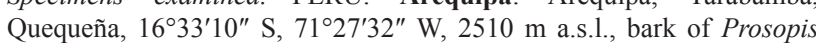
sp., 11 Apr. 2016, C. Lado 24223 leg. (MA-Fungi 91653). Cusco: Anta, Limatambo, route PE-3S, km 888, 13⒉ $9^{\prime} 10^{\prime \prime} \mathrm{S}, 72^{\circ} 27^{\prime} 13^{\prime \prime} \mathrm{W}, 2501 \mathrm{~m}$ a.s.l., leaf of Furcraea andina, 18 Apr. 2016, C. Lado 24503 leg. (MAFungi 91654); same data as for preceeding, C. Lado 24506 leg. (MAFungi 91655). Huancavelica: Angaraes, route PE-26B, km 158, 4 km west of Laramate, $13^{\circ} 01^{\prime} 48^{\prime \prime} \mathrm{S}, 74^{\circ} 23^{\prime} 48^{\prime \prime} \mathrm{W}, 2890 \mathrm{~m}$ a.s.l., grass leaf, 22 Apr. 2017, C. Lado 25038 leg. (MA-Fungi 91656); Tayacaja, route PE$3 \mathrm{~S}$, km 198, Izcuchaca, $7 \mathrm{~km}$ south of Izcuchaca, $12^{\circ} 31^{\prime} 17^{\prime \prime} \mathrm{S}, 74^{\circ} 56^{\prime} 50^{\prime \prime}$ W, 2840 m a.s.1., twigs, 25 Apr. 2017, C. Lado 25236 leg. (MA-Fungi 91657); same data as for preceeding, C. Lado 25242 leg. (MA-Fungi 91658). Lima: Yauyos, Calachota, route PE-24, km 104, 12³8'55.5" S, $75^{\circ} 58^{\prime} 01.8^{\prime \prime} \mathrm{W}, 1700 \mathrm{~m}$ a.s.1., inflorescence of Puya sp., moist chamber culture pH 8.28, 1 Oct. 2012, A. Estrada-Torres 12268 leg. (TLXM); same data as for preceeding, moist chamber culture $\mathrm{pH} 7.71, \mathrm{~A}$. Estrada- 
Torres 12272 leg. (TLXM). Piura: Huancabamba, route PE-04E, km

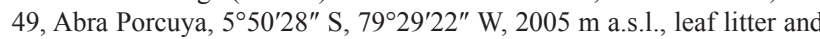
twigs, 10 May 2014, C. Lado $23498 b$ leg. (MA-Fungi 91118). Tacna: Palca, Huanune, route PE-40, km 53, 3 kms west of Palca, 1747'17.2' $\mathrm{S}, 69^{\circ} 58^{\prime} 01.2^{\prime \prime} \mathrm{W}, 2875 \mathrm{~m}$ a.s.1., ground litter, moist chamber culture $\mathrm{pH}$ 4.96, 5 Oct. 2012, S.L. Stephenson 28846 leg. (UARK).

Notes.-It is well known in Peru, from Arequipa and Madre de Dios to Loreto and Piura (Wrigley de Basanta \& al. 2008a; Rojas \& Stephenson 2013; Lado \& al. 2016)

\section{Didymium trachysporum G.Lister}

Specimens examined.-PERU. Huancavelica: Tayacaja, route PE-3S, $\mathrm{km}$ 198, Izcuchaca, $7 \mathrm{~km}$ south of Izcuchaca, 12 ${ }^{\circ} 31^{\prime} 17^{\prime \prime} \mathrm{S}, 74^{\circ} 56^{\prime} 50^{\prime \prime}$ W, 2840 m a.s.1., twigs, 25 Apr. 2017, C. Lado 25238 leg. (MA-Fungi 91659).

Notes.-The Neotropical distribution of this species is limited to Argentina, Honduras, Mexico and Peru. In Peru this is the second record. It was previously known from Cuzco (Rojas \& al. 2011).

\section{${ }^{\circ}$ Didymium umbilicatum D.Wrigley, Lado \& Estrada}

Specimens examined.-PERU. Ancash: Huaylas, Caraz, Pueblo Libre,

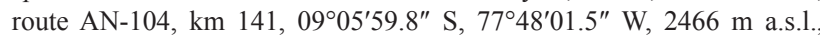
leaves of Agave americana, 20 Apr. 2013, C. Lado 22933 leg. (MA-Fungi 91036).

Notes.-This species, described from Mexico in succulent plants (Wrigley de Basanta \& al. 2008b), is reported for the first time in South America. The only collection from Peru has collapsed spores of a diameter of around $12 \mu \mathrm{m}$, but the rest of the characters agree with the original description.

\section{Didymium vaccinum (Durieu \& Mont.) Buchet}

Specimens examined.-PERU. Ancash: Huaraz, Pariacoto, route PE-14, km 79, 09³2'16.1" S, 7746'07.4" W, 2569 m a.s.1., leaves of Agave americana, 17 Apr. 2013, C. Lado 22664 leg. (MA-Fungi 91003); same data as for preceeding, C. Lado 22674 leg. (MA-Fungi 91015); same data as for preceeding, C. Lado 22675 leg. (MA-Fungi 91016); same data as for preceeding, C. Lado 22676 leg. (MA-Fungi 91017); Huaylas, Caraz, Pueblo Libre, route AN-104, km 141, 0905'59.8" S, 7748'01.5" W, 2466 m a.s.1., leaves of Agave americana, 20 Apr. 2013, C. Lado 22938 leg. (MA-Fungi 91041). Apurimac: Abancay, Abancay, Auquibamba

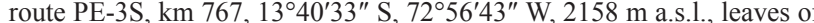
Agave americana, 19 Apr. 2016, C. Lado 24548 leg. (MA-Fungi 91660).

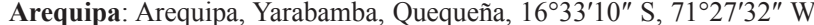
$2510 \mathrm{~m}$ a.s.1., leaf litter of Puya cylindrica, moist chamber culture $\mathrm{pH}$ 7.92, 11 Apr. 2016, D. Wrigley de Basanta 3823 leg. (dwb). Cajamarca: Cajamarca, San Juan, route PE-08, km 133, Puente San Juan, 07 16'44.2" S, 78³1'47.3" W, 1915 m a.s.1., inflorescence of Puya sp., 15 Apr. 2013 , C. Lado 22600 leg. (MA-Fungi 90997). La Libertad: Otuzco, Plazapalpa, route PE-10A, $\mathrm{km} \mathrm{56}$, at the junction to Salpo, 07 59'19.1" S, $78^{\circ} 39^{\prime} 21.2^{\prime \prime}$ W, 1742 m a.s.l., leaves of Puya sp., 12 Apr. 2013, C. Lado 22464 leg. (MA-Fungi 90962); same data as for preceeding, C. Lado 22477 leg. (MA-Fungi 90976). Lima: Huarochirí, Matucana, Chacahuaro, route PE-

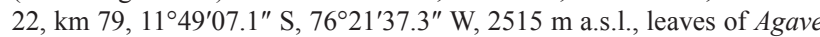
americana, 23 Sep. 2012, C. Lado 21722 leg. (MA-Fungi 90783); same data as for preceeding, C. Lado 21726 leg. (MA-Fungi 90788); same data as for preceeding, C. Lado 21737 leg. (MA-Fungi 90804); same data as for preceeding, C. Lado 21738 leg. (MA-Fungi 90806); same data as for preceeding, C. Lado 21745 leg. (MA-Fungi 90815); Huarochirí, San

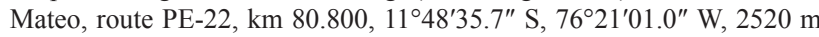
a.s.1., leaves of Puya sp., moist chamber culture pH 7.28, 23 Sep. 2012, D. Wrigley de Basanta 3576 leg. (dwb); same data as for preceeding, aerial litter, moist chamber culture pH 6.5, S.L. Stephenson 30100 leg. (UARK); same data as for preceeding, moist chamber culture $\mathrm{pH}$ 6.5, S.L. Stephenson 30116 leg. (UARK); Canta, $2 \mathrm{~km}$ south of Canta, $11^{\circ} 28^{\prime} 30^{\prime \prime}$ S, $76^{\circ} 37^{\prime} 45^{\prime \prime}$ W, 2700 m a.s.1., cladode of Opuntia sp., 18 May 2014,
C. Lado 23624 leg. (MA-Fungi 91126); same data as for preceeding, $C$. Lado 23626 leg. (MA-Fungi 91128); same data as for preceeding, C. Lado 23627 leg. (MA-Fungi 91721); same data as for preceeding, C. Lado 23633 leg. (MA-Fungi 91135); Canta, $6 \mathrm{~km}$ south of Canta, 11 ${ }^{\circ} 29^{\prime} 11^{\prime \prime}$ S, 76 $38^{\prime} 38^{\prime \prime}$ W, 2406 m a.s.1., leaves of Puya sp., 18 May 2014, C. Lado 23637 leg. (MA-Fungi 91139)

Notes.-In Peru it was previously reported from Ancash, Arequipa, Ica and Cusco (Rojas \& al. 2011; Lado \& al. 2016).

Didymium wildpretii Mosquera, Estrada, Beltrán-Tej., D.Wrigley \& Lado

Specimens examined.-PERU. Lima: Huarochirí, San Bartolomé, $11^{\circ} 54^{\prime} 33.3^{\prime \prime} \mathrm{S}, 76^{\circ} 31^{\prime} 34.0^{\prime \prime} \mathrm{W}, 1580 \mathrm{~m}$ a.s.1., epidermis of Haageocereus acranthus, moist chamber culture pH 7.52, 22 Sep. 2012, D. Wrigley de Basanta 3597 leg. (dwb); same data as for preceeding, moist chamber culture pH 8.22, D. Wrigley de Basanta 3598 leg. (dwb); same data as for preceeding, moist chamber culture pH 7.82, D. Wrigley de Basanta 3602 leg. (dwb); same data as for preceeding, cactus, moist chamber culture $\mathrm{pH}$ 8.28, S.L. Stephenson 30107 leg. (UARK); same data as for preceeding, moist chamber culture pH 8.33, S.L. Stephenson 30181 leg. (UARK).

Notes.-This species, associated with succulent plants, is known in the Neotropics only from Mexico and the South of Peru, the region of Ica, Moquegua and Tacna (Lado \& al. 2016). With these records from Lima, its distribution is enlarged.

\section{Echinostelium arboreum H.W.Keller \& T.E.Brooks}

Specimens examined.-PERU. Lima: Huarochirí, San Bartolomé, $11^{\circ} 54^{\prime} 33.3^{\prime \prime} \mathrm{S}, 76^{\circ} 31^{\prime} 34.0^{\prime \prime} \mathrm{W}, 1580 \mathrm{~m}$ a.s.1., epidermis of Haageocereus acranthus, moist chamber culture $\mathrm{pH}$ 7.82, 22 Sep. 2012, D. Wrigley de Basanta 3588 leg. (dwb); same data as for preceeding, moist chamber culture pH 8.22, D. Wrigley de Basanta 3609 leg. (dwb); Huarochirí,

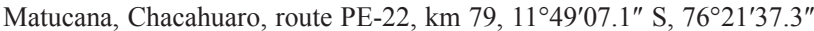
W, $2515 \mathrm{~m}$ a.s.l., litter of Espostoa lanata, moist chamber culture $\mathrm{pH}$ 7.83, 23 Sep. 2012, D. Wrigley de Basanta 3587 leg. (dwb); same data as for preceeding, moist chamber culture $\mathrm{pH} 7.97$, D. Wrigley de Basanta 3590 (dwb); Yauyos, Calachota, route PE-24, km 104, 12³8'55.5" S, $75^{\circ} 58^{\prime} 01.8^{\prime \prime} \mathrm{W}, 1700 \mathrm{~m}$ a.s.1., leaf base of Puya sp., moist chamber culture pH 7.38, 1 Oct. 2012, D. Wrigley de Basanta 3611 leg. (dwb); same data as for preceeding, moist chamber culture $\mathrm{pH} 7.39$, D. Wrigley de Basanta 3613 leg. (dwb); same data as for preceeding, moist chamber culture $\mathrm{pH}$ 7.39, D. Wrigley de Basanta 3614 leg. (dwb)

Notes.-In Peru it was previously reported from Ancash and Piura (Lado \& al. 2016)

\section{Echinostelium colliculosum K.D.Whitney \& H.W.Keller}

Specimens examined.-PERU. Lima: Huarochirí, Matucana, Chacahuaro, route PE-22, $\mathrm{km} \mathrm{79,} 11^{\circ} 49^{\prime} 07.1^{\prime \prime} \mathrm{S}, 76^{\circ} 21^{\prime} 37.3^{\prime \prime} \mathrm{W}, 2515 \mathrm{~m}$ a.s.1., litter of Espostoa lanata, moist chamber culture pH 7.96, 23 Sep. 2012, D. Wrigley de Basanta 3586 leg. (dwb); same data as for preceeding, moist chamber culture pH 7.97, D. Wrigley de Basanta 3603 leg. (dwb); Yauyos, Yauyos,

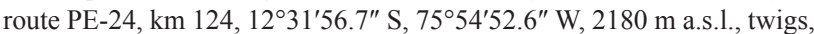
moist chamber culture $\mathrm{pH}$ 6.06, 1 Oct. 2012, S.L. Stephenson 28324 leg. (UARK).

Notes.-In Peru it was previously reported from Ancash and Piura (Lado \& al. 2016)

\section{Echinostelium minutum de Bary}

Specimens examined.-PERU. Ancash: Huaylas, Caraz, Pueblo Libre, route $\mathrm{AN}-104, \mathrm{~km} 141,09^{\circ} 05^{\prime} 59.8^{\prime \prime} \mathrm{S}, 77^{\circ} 48^{\prime} 01.5^{\prime \prime} \mathrm{W}, 2466 \mathrm{~m}$ a.s.l., leaf 
bases of Furcraea occidentalis, moist chamber culture pH 8.06, $20 \mathrm{Apr}$ 2013, D. Wrigley de Basanta 3686 leg. (dwb).

Notes.-In Peru it was previously reported from the tropical forests of Loreto and Madre de Dios (Wrigley de Basanta \& al. 2008a; Rojas \& Stephenson 2013) and arid lands of Ancash (Lado \& al. 2016).

\section{Fuligo septica (L.) F.H.Wigg.}

Specimens examined.-PERU. Apurimac: Abancay, $5 \mathrm{~km}$ from the Cunyac bridge, route PE-3S, Km 864, 133'ㅇ' $01^{\prime \prime} \mathrm{S}, 72^{\circ} 36^{\prime} 43^{\prime \prime} \mathrm{W}, 1954 \mathrm{~m}$ a.s.1., stem of Agave americana, 21 Apr. 2016, C. Lado 24611 leg. (MAFungi 91661).

Notes.-In Peru it was previously reported from tropical forests of Madre de Dios (Rojas \& al. 2011; Rojas \& Stephenson 2013), but also from the arid lands of Lambayeque and Piura (Lado \& al. 2016).

\section{Hemitrichia calyculata (Speg.) M.L.Farr}

Specimens examined.-PERU. Apurimac: Abancay, Puente Cunyac over the Apurímac river, route PE-3S, km 869, community Ccarhua, 133' $55^{\prime \prime}$ S, 72³4'28" W, 1936 m a.s.1., wood, 18 Apr. 2016, C. Lado 24511 leg. (MA-Fungi 91662); same data as for preceeding, C. Lado $24512 \mathrm{leg}$. (MA-Fungi 91663); Abancay, Abancay, Auquibamba, route PE-3S, km $767,13^{\circ} 40^{\prime} 33^{\prime \prime} \mathrm{S}, 72^{\circ} 56^{\prime} 43^{\prime \prime} \mathrm{W}, 2158 \mathrm{~m}$ a.s.1., leaves of Agave americana, 19 Apr. 2016, C. Lado 24551 leg. (MA-Fungi 91664); Abancay, 5 km from the Cunyac bridge, route PE-3S, km 864, 13³3'01" S, 72 $36^{\prime} 43^{\prime \prime} \mathrm{W}$, 1954 m a.s.1., leaves of Agave americana, 21 Apr. 2016, C. Lado 24610 leg. (MA-Fungi 91665).

Notes.-It is widely distributed throughout the Neotropics and usually associated with the wood of tropical forests. In Peru previously reported from Madre de Dios (Rojas \& Stephenson 2013). In BPI there are two collections from Peru, one (BPI 838053) that is probably the specimen mentioned by Farr (1976: 96) in the monograph of Flora Neotropica, without a locality, and the second (BPI 837992) from Tingo María (Huánuco).

\section{o Hemitrichia succulenticola G.Moreno, A.Castillo, López-Villalba \& A.Sánchez}

Specimens examined.-PERU. Huancavelica: Angaraes, route PE-26B,

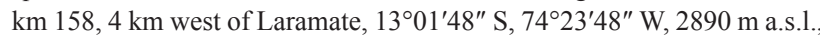
cladode of Opuntia ficus-indica, 22 Apr. 2017, C. Lado 25042 leg. (MAFungi 91666). Lima: Canta, $2 \mathrm{~km}$ south of Canta, $11^{\circ} 28^{\prime} 30^{\prime \prime} \mathrm{S}, 76^{\circ} 37^{\prime} 45^{\prime \prime}$ W, 2700 m a.s.1., cladode of Opuntia sp., 18 May 2014, C. Lado 23620 leg. (MA-Fungi 91122); same data as for preceeding, C. Lado $23621 \mathrm{leg}$. (MA-Fungi 91123); same data as for preceeding, C. Lado $23623 \mathrm{leg}$. (MA-Fungi 91125); same data as for preceeding, C. Lado $23626 \mathrm{leg}$. (MA-Fungi 91718); same data as for preceeding, C. Lado $23627 \mathrm{leg}$. (MA-Fungi 91719); same data as for preceeding, C. Lado $23628 \mathrm{leg}$. (MA-Fungi 91130); same data as for preceeding, C. Lado $23629 \mathrm{leg}$. (MA-Fungi 91131); same data as for preceeding, C. Lado $23630 \mathrm{leg}$. (MA-Fungi 91132); same data as for preceeding, C. Lado 23632 leg. (MA-Fungi 91134); same data as for preceeding, C. Lado $23633 \mathrm{leg}$. (MA-Fungi 91720); same data as for preceeding, C. Lado $23634 \mathrm{leg}$. (MA-Fungi 91136); same data as for preceeding, C. Lado $23635 \mathrm{leg}$. (MA-Fungi 91137); same data as for preceeding, C. Lado $23636 \mathrm{leg}$. (MA-Fungi 91138).

Notes.-This species develops usally on species of Opuntia. In the Neotropics it was only reported from Mexico (Moreno \& al. 2017). This recently described species is very near to Hemitrichia minor G.Lister, but differs in the size of the sporocarps $(0.4-0.8 \mathrm{~mm}$ in diameter vs. $0.2-$ $0.4 \mathrm{~mm}$ in Hemitrichia minor) and the size of the spores $(12-15 \mu \mathrm{m}$ in diameter vs. 9-10 $\mu \mathrm{m}$ in Hemitrichia minor).

\section{* Lamproderma muscorum (Lév.) Hagelst. Fig. 6.}

Specimens examined.-PERU. La Libertad: Otuzco, Plazapalpa, route PE-10A, km 56, at the junction to Salpo, 0759'19.1" S, 78³9'21.2" W, 1742 m a.s.1., leaves of Puya sp., 12 Apr. 2013, C. Lado $22452 a$ leg. (MA-Fungi 90949); same data as for preceeding, litter and twigs of a herbaceous plant, C. Lado 22486 leg. (MA-Fungi 90985); same data as for preceeding, C. Lado 22487 leg. (MA-Fungi 90986).

Notes.-This species, described by Léveillé (1863), originally from Colombia as Enerthenema muscorum Lév., has also been reported from Costa Rica, Brazil, Ecuador, El Salvador, Mexico and Venezuela. This is the first record for Peru. The specimens studied have grouped sporocarps (fig. 6a), with a black, shining and flat stalk (fig. 6b); the peridium is membranous, very persistent, with blue or green shades, and fragmented in patches (fig. 6a-c). The capillitial threads, radiating from the apex of the columella, are dichotomously branched, but with very few anastomoses, dark brown to blackish, uniform in diameter, only paler and attenuated at the tips (fig. 6d), and the spores are black in mass, dark brown to dark purplish brown by TL, ornamented with prominent and irregularly distributed, blunt spines of around $1 \mu \mathrm{m}$ long. The collections C. Lado 22486 leg. and C. Lado $22487 \mathrm{leg}$. have the primary branches of the capillitium paler (fig. 6e, f) and resemble Lamproderma scintillans, but the rest of the characters, including the dark and spiny spores, agrees with the description provided by Farr (1976: 250-251) for Lamproderma muscorum.

\section{Lamproderma scintillans (Berk. \& Broome) Morgan}

Specimens examined.-PERU. Piura: Huancabamba, route PE-04E, km

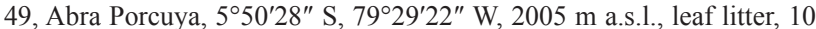
May 2014, C. Lado 23498c leg. (MA-Fungi 91669).

Notes.-It is widely distributed throughout the Neotropics. In Peru it was only previously reported from the tropical forests of Madre de Dios (Rojas \& al. 2011; Rojas \& Stephenson 2013).

\section{* Licea castanea G.Lister}

Specimens examined.-PERU. Ancash: Huaraz, Pariacoto, route PE-14, km 79, 09³2'16.1" S, 7746'07.4" W, 2569 m a.s.1., leaves of Agave americana, 17 Apr. 2013, C. Lado 22670 leg. (MA-Fungi 91009).

Notes.-In the Neotropics it has also been reported from Brazil, Mexico, Costa Rica (Rojas \& al. 2015) and Paraguay (McHugh 2009). This is the first record for Peru.

\section{* Licea deplanata Kowalski}

Specimens examined.-PERU. Ancash: Huari, $21 \mathrm{~km}$ from Huari towards San Marcos, 9 $9^{\circ} 8^{\prime} 02^{\prime \prime}$ S, $77^{\circ} 08^{\prime} 37^{\prime \prime}$ W, $2827 \mathrm{~m}$ a.s.1., branch of Baccharis latifolia, 21 May 2014, C. Lado 23728 leg. (MA-Fungi 91670).

Notes.-Only two previous records are known from the Neotropics, in Mexico (Rojas \& al. 2010) and Argentina (Lado \& al. 2014). Our record considerably enlarges the distribution of this species.

\section{* Licea rufocuprea Nann.-Bremek. \& Y.Yamam.}

Specimens examined.-PERU. La Libertad: Otuzco, Plazapalpa, route PE-10A, km 56, at the junction to Salpo, 0759'19.1" S, 78³9'21.2" W, $1742 \mathrm{~m}$ a.s.1., leaves of Puya sp., moist chamber culture pH 7.07, 12 Apr. 2013, D. Wrigley de Basanta 3682 leg. (dwb).

Notes.-This collection is of cone-shaped, copper-coloured, sessile sporocarps with circumcissile dehiscence, the upper peridium dehiscing whole as a cap leaving a shallow concave base. Spores are pale rosy brown, closely warted, with diameter 9.5-11 $\mu \mathrm{m}$. It was described in 1987 from Japan (Nannenga-Bremekamp \& Yamamoto 1987), but very characteristic. It was reported by the authors from Madagascar (Wrigley de Basanta \& al. 2013) and as 'Licea sp.' from Paraguay (McHugh 2009). 
Also reported from Brazil (De Lima \& Cavalcanti 2017) and Panama (Rojas \& al. 2017). Otherwise only six georeferenced occurences in GBIF. It is a rare species, more often on bark, recorded here for the first time from Peru.

Licea succulenticola Mosquera, Lado, Estrada \& BeltránTej.

Specimens examined.-PERU. Ancash: Huaraz, Pariacoto, route PE-14, km 79, 09³2'16.1" S, 7746'07.4" W, 2569 m a.s.l., leaves of Agave americana, 17 Apr. 2013, C. Lado 22676 leg. (MA-Fungi 91018) Huancavelica: Tayacaja, route PE-3S, km 193, Izcuchaca, $2 \mathrm{~km}$ south of Izcuchaca, $12^{\circ} 30^{\prime} 23^{\prime \prime}$ S, 74 ${ }^{\circ} 58^{\prime} 40^{\prime \prime}$ W, 2856 m a.s.1., leaves of Agave americana, 25 Apr. 2017, C. Lado 25260 leg. (MA-Fungi 91671). Lima: Huarochirí, San Bartolomé, 1154'33.3" S, 76³1'34.0” W, 1580 m a.s.1., epidermis of Haageocereus acranthus, moist chamber culture $\mathrm{pH} 7.82,22$ Sep. 2012, D. Wrigley de Basanta 3600 leg. (dwb); Huarochirí, Matucana,

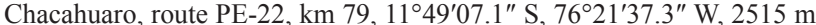
a.s.1., litter of Espostoa lanata, moist chamber culture pH 7.97, 23 Sep. 2012, D. Wrigley de Basanta 3606 leg. (dwb).

Notes.-This species is distributed throughout the arid lands of the Neotropics (Argentina, Brazil, Chile, Ecuador, Mexico and Paraguay), and usually linked to succulent plants. In Peru it was previously reported by Lado \& al. (2016) from Ancash, and now found also in Lima and Huancavelica.

\section{* Perichaena calongei Lado, D. Wrigley \& Estrada}

Specimens examined.-PERU. Ancash: Huaylas, Caraz, Pueblo Libre,

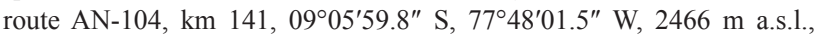
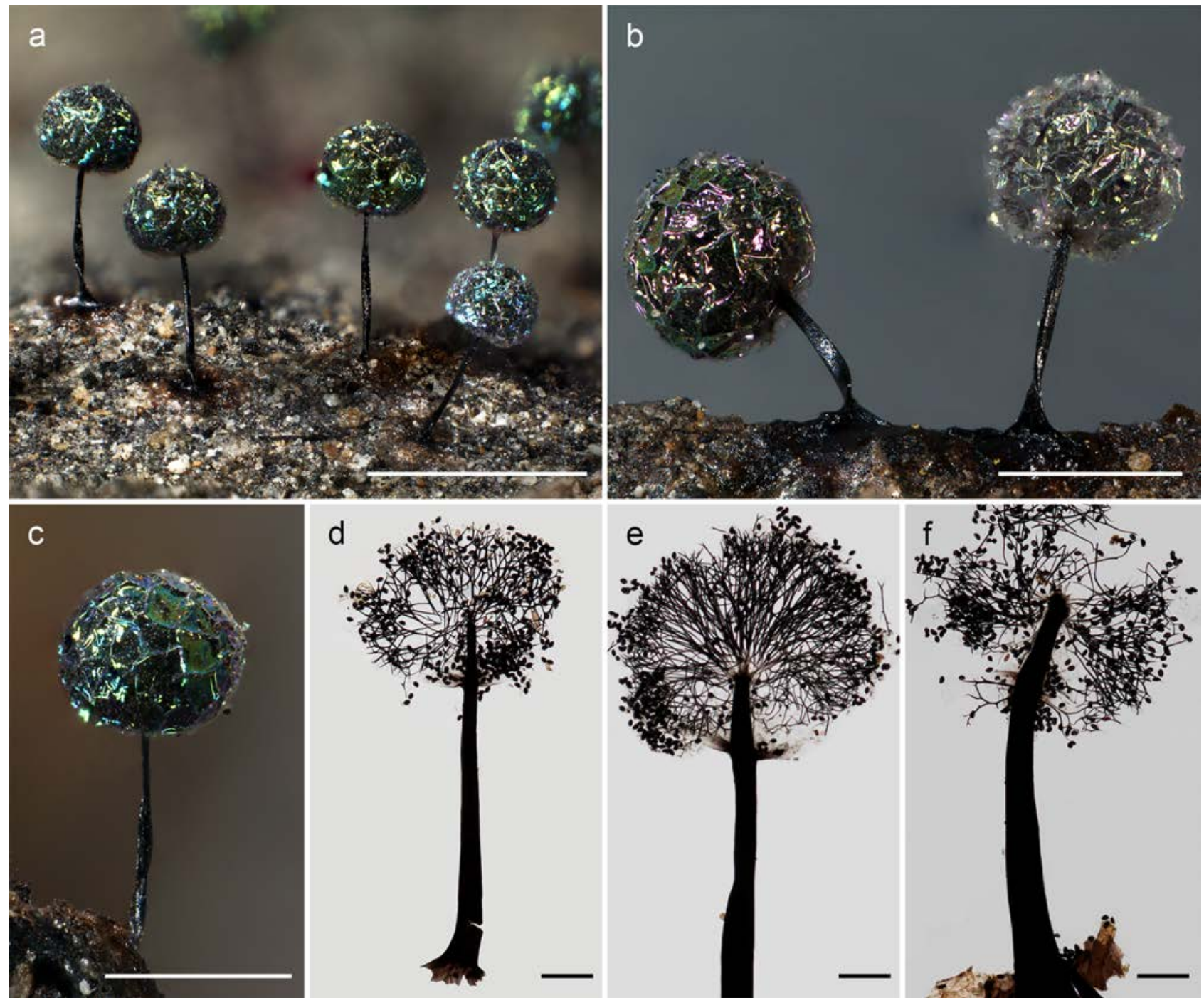

Fig. 6. Lamproderma muscorum (Lév.) Hagelst.: a, group of sporocarps; b, two sporocarps showing the flat stalk and the persistent peridium; c, sporotheca with bluish or greenish tints and persistent peridium; d, sporocarps by TL showing the paler primary branches of the capillitium. e, detail of the sporotheca by TL showing the capillitium radiating from the apex of the columella, the primary branches slightly paler at the beginning; $\mathbf{f}$, sporotheca by TL showing the capillitium radiating from the columella. [a-d, C. Lado 22452 leg. (MA-Fungi 90949); e, C. Lado 22486 leg. (MA-Fungi 90985); f, C. Lado 22487 leg. (MA-Fungi 90986); scale bars: a, $1 \mathrm{~mm}$; b, c, $0.5 \mathrm{~mm}$; d-f, $100 \mu \mathrm{m}$. 
leaves of Puya angusta, moist chamber culture $\mathrm{pH}$ 7.78, 20 Apr. 2013, D. Wrigley de Basanta 3692 leg. (dwb). Huancavelica: Tayacaja, route PE$3 \mathrm{~S}, \mathrm{~km} \mathrm{198}$, Izcuchaca, $7 \mathrm{~km}$ south of Izcuchaca, 12 ${ }^{\circ} 31^{\prime} 17^{\prime \prime} \mathrm{S}, 74^{\circ} 56^{\prime} 50^{\prime \prime}$ W, 2840 m a.s.l., leaves of Puya sp., 25 Apr. 2017, C. Lado 25248 leg. (MA-Fungi 91672); same data as for preceeding, C. Lado 25249 leg. (MA-Fungi 91673); Tayacaja, route PE-3S, km 193, Izcuchaca, 2 km south of Izcuchaca, 12 $2^{\circ} 30^{\prime} 23^{\prime \prime} \mathrm{S}, 74^{\circ} 58^{\prime} 40^{\prime \prime} \mathrm{W}, 2856 \mathrm{~m}$ a.s.1., leaves of Agave americana, 25 Apr. 2017, C. Lado 25259 leg. (MA-Fungi 91674). La Libertad: Otuzco, Plazapalpa, route PE-10A, km 56, at the junction to Salpo, 07 $59^{\prime} 19.1^{\prime \prime}$ S, $78^{\circ} 39^{\prime} 21.2^{\prime \prime}$ W, $1742 \mathrm{~m}$ a.s.1., leaves of Puya sp., 12 Apr. 2013, C. Lado 22460 leg. (MA-Fungi 90958). Lima: Huarochirí,

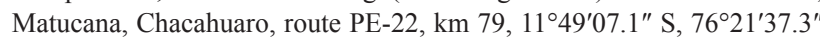
W, 2515 m a.s.l., leaf of Agave americana, 23 Sep. 2012, C. Lado 21718 leg. (MA-Fungi 90779); same data as for preceeding, C. Lado 21721 leg. (MA-Fungi 90782); same data as for preceeding, C. Lado 21724 leg. (MA-Fungi 90785); same data as for preceeding, C. Lado 21725 leg. (MA-Fungi 90786); same data as for preceeding, C. Lado 21726 leg. (MA-Fungi 90789); same data as for preceeding, C. Lado 21728 leg. (MA-Fungi 90790); same data as for preceeding, C. Lado 21729 leg. (MA-Fungi 90792); same data as for preceeding, C. Lado 21733 leg. (MA-Fungi 90797); same data as for preceeding, C. Lado 21734 leg. (MA-Fungi 90799); same data as for preceeding, C. Lado 21735 leg. (MA-Fungi 90801); same data as for preceeding, C. Lado 21741 leg. (MA-Fungi 90809); same data as for preceeding, C. Lado 21743 leg. (MA-Fungi 90812); same data as for preceeding, C. Lado 21744 leg. (MA-Fungi 90813). Tacna: Palca, Huanune, route PE-40, km 53, $3 \mathrm{kms}$ west of Palca, 1747'17.2" S, 6958'01.2" W, 2875 m a.s.1., litter of Corryocactus brevistylus, 5 Oct. 2012, C. Lado 22109 leg. (MA-Fungi 90841).

Notes.-The species, described from arid lands of Argentina (Lado \& al. 2011), is also distributed in Brazil (Araújo \& al. 2015; Cavalcanti \& al. 2016). Our records are the first from Peru (Lima, Tacna, La Libertad, Ancash and Huancavelica) and enlarge the distribution to the Pacific coast of South America. All the specimens examined show the distinctive characters of this species such as the dehiscence of the peridium by very well marked polygonal plates and the spiny capillitial threads (Lado \& al. 2009).

\section{Perichaena chrysosperma (Curr.) Lister}

Specimens examined.-PERU. Apurimac: Abancay, $5 \mathrm{~km}$ from the Cunyac bridge, route PE-3S, Km 864, 133'01" S, 72³6'43" W, 1954 m a.s.1., litter of Browningia viridis, 21 Apr. 2016, C. Lado 24608 leg. (MA-Fungi 91675). Cajamarca: Cajamarca, San Juan, route PE-08, km 133, Puente San Juan, 07¹6'44.2" S, 78³1'47.3" W, 1915 m a.s.1., inflorescence of Puya sp., 15 Apr. 2013, C. Lado 22601 leg. (MA-Fungi 90998); ; same data as for preceeding, inflorescence and fruit of Puya sp., C. Lado 22604 leg. (MA-Fungi 91002). La Libertad: Otuzco, Plazapalpa, route PE-10A, km 56, at the junction to Salpo, 0759'19.1" S, 78³9'21.2' W, 1742 m a.s.1., leaves of Furcraea americana, 12 Apr. 2013, C. Lado 22449 leg. (MA-Fungi 90946); same data as for preceeding, leaves of Puya sp., C. Lado $22452 b$ leg. (MA-Fungi 90950). Lima: Huarochirí, San Bartolomé, $11^{\circ} 54^{\prime} 33.3^{\prime \prime}$ S, 76³1'34.0" W, 1580 m a.s.l., twigs, moist chamber culture pH 6.43, 22 Sep. 2012, S.L. Stephenson 30000 leg. (UARK); same data as for preceeding, moist chamber culture $\mathrm{pH} 6.6$, S.L. Stephenson 30069 leg. (UARK); same data as for preceeding, moist chamber culture pH 7.18, S.L. Stephenson 30087 leg. (UARK); same data as for preceeding, moist chamber culture $\mathrm{pH}$ 6.38, S.L. Stephenson 30120 leg. (UARK); Yauyos, Yauyos, Auco, route PE-24, km 110, 12³6'45.3" $\mathrm{S}, 75^{\circ} 58^{\prime} 31.6^{\prime \prime} \mathrm{W}, 1775 \mathrm{~m}$ a.s.1., twigs, moist chamber culture $\mathrm{pH}$ 6.74, 1 Oct. 2012, S.L. Stephenson 28363 leg. (UARK); same data as for preceeding, moist chamber culture pH 6.76, S.L. Stephenson 28962 leg. (UARK).

Notes.-In Peru it was previously reported from Ayacucho, Cajamarca and Madre de Dios (Rojas \& al. 2011; Rojas \& Stephenson 2013; Lado \& al. 2016).

\section{Perichaena depressa Lib.}

Specimens examined.-PERU. Ancash: Bolognesi, Raquia, route PE-

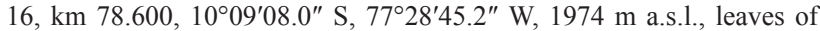
Puya ferruginea, 24 Apr. 2013, C. Lado 23181 leg. (MA-Fungi 91069). Apurimac: Abancay, Puente Cunyac over the Apurímac river, route PE-

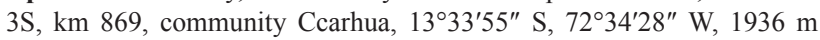
a.s.1., litter of a cactus, 18 Apr. 2016, C. Lado 24514 leg. (MA-Fungi 91680); same data as for preceeding, leaves of Puya sp., C. Lado 24515 leg. (MA-Fungi 91681); Abancay, Auquibamba, route PE-3S, km 765, $13^{\circ} 40^{\prime} 58^{\prime \prime} \mathrm{S}, 72^{\circ} 57^{\prime} 26^{\prime \prime} \mathrm{W}, 2265 \mathrm{~m}$ a.s.1., leaves of Furcraea andina, 19 Apr. 2016, C. Lado 24540 leg. (MA-Fungi 91682); same data as for preceeding, C. Lado 24541 leg. (MA-Fungi 91683). Arequipa: Arequipa,

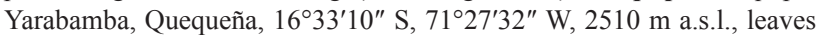
of Puya cylindrica, 11 Apr. 2016, C. Lado 24213 leg. (MA-Fungi 91676); same data as for preceeding, C. Lado 24214 leg. (MA-Fungi 91677). Cusco: Anta, Limatambo, route PE-3S, km 888, 1329'10" S, 72²7'13" W, 2501 m a.s.1., leaves of Furcraea andina,18 Apr. 2016, C. Lado 24497 leg. (MA-Fungi 91678); same data as for preceeding, C. Lado 24505 leg. (MA-Fungi 91679). Huancavelica: Tayacaja, route PE-3S, km 198,

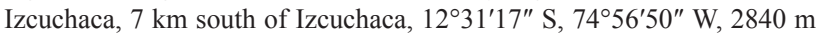
a.s.1., twigs, 25 Apr. 2017, C. Lado 25256 leg. (MA-Fungi 91684); Tayacaja, route PE-3S, km 193, Izcuchaca, $2 \mathrm{~km}$ south of Izcuchaca, $12^{\circ} 30^{\prime} 23^{\prime \prime} \mathrm{S}, 74^{\circ} 58^{\prime} 40^{\prime \prime} \mathrm{W}, 2856 \mathrm{~m}$ a.s.1., leaves of Agave americana, 25 Apr. 2017, C. Lado 25259 leg. (MA-Fungi 91685); same data as for preceeding, C. Lado 25260 leg. (MA-Fungi 91686); same data as for preceeding, C. Lado 25262 leg. (MA-Fungi 91687). Lima: Huarochirí, San Bartolomé, $11^{\circ} 54^{\prime} 33.3^{\prime \prime} \mathrm{S}, 7^{\circ} 31^{\prime} 34.0^{\prime \prime} \mathrm{W}, 1580 \mathrm{~m}$ a.s.1., twigs, moist chamber culture pH 6.43, 22 Sep. 2012, S.L. Stephenson 30214 leg. (UARK); Huarochirí, Matucana, Chacahuaro, route PE-22, km 79, $11^{\circ} 49^{\prime} 07.1^{\prime \prime} \mathrm{S}, 76^{\circ} 21^{\prime} 37.3^{\prime \prime} \mathrm{W}, 2515 \mathrm{~m}$ a.s.l., leaves of Agave americana, 23 Sep. 2012, C. Lado 21716 leg. (MA-Fungi 90776); same data as for preceeding, twigs, moist chamber culture pH 6.43, S.L. Stephenson 29161 leg. (UARK); same data as for preceeding, ground litter, moist chamber culture pH 5.58, S.L. Stephenson 29169 leg. (UARK); Huarochirí, San

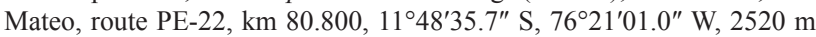
a.s.1., aerial litter, moist chamber culture pH 6.35, 23 Sep. 2012, S.L. Stephenson 29997 leg. (UARK); same data as for preceeding, moist chamber culture pH 6.5, S.L. Stephenson 30062 leg. (UARK); same data as for preceeding, moist chamber culture $\mathrm{pH}$ 6.5, S.L. Stephenson 30110 leg. (UARK); Yauyos, Calachota, route PE-24, km 104, 12³8'55.5” S, $75^{\circ} 58^{\prime} 01.8^{\prime \prime} \mathrm{W}, 1700 \mathrm{~m}$ a.s.1., inflorescence of Puya sp., moist chamber culture pH 7.71, 1 Oct. 2012, A. Estrada-Torres 12344 leg. (TLXM); same data as for preceeding, moist chamber culture $\mathrm{pH} 8.28$, A. EstradaTorres 12345 leg. (TLXM).

Notes.-In Peru it was previously known from Ancash, Arequipa, Cajamarca, Cuzco, Lima and Tacna (Rojas \& al. 2011; Rojas \& Stephenson 2013; Lado \& al. 2016).

\section{Perichaena quadrata T.Macbr. Fig. 7a-c.}

Specimens examined.-PERU. Ancash: Pallasca, Ancos, route PE-3N, km 104, Cocabal, 08²9'24.7" S, 7806'32.5" W, 1605 m a.s.l., leaves of Puya sp., 11 Apr. 2013, C. Lado 22409 leg. (MA-Fungi 90913); same data as for preceeding, C. Lado 22410 leg. (MA-Fungi 90914); Huaraz, Pariacoto, route PE-14, km 79, 09³2'16.1" S, 77²6'07.4" W, 2569 m a.s.1., leaves of Agave americana, 17 Apr. 2013, C. Lado 22667 leg. (MAFungi 91005); Huaylas, Caraz, Sucre, route PE-3N, km 665, 08 56'12.7" S, 7750'30.8" W, 2044 m a.s.1., twigs, 18 Apr. 2013, C. Lado 22759 leg. (MA-Fungi 91025); Huaylas, Caraz, Pueblo Libre, route AN-104, km 141, $09^{\circ} 05^{\prime} 59.8^{\prime \prime} \mathrm{S}, 77^{\circ} 48^{\prime} 01.5^{\prime \prime} \mathrm{W}, 2466 \mathrm{~m}$ a.s.1., leaves of Puya angusta, moist chamber culture pH 7.78, 20 Apr. 2013, D. Wrigley de Basanta 3691 leg. (dwb); same data as for preceeding, inflorescence of Puya angusta, moist chamber culture $\mathrm{pH} 6.74$, A. Estrada-Torres 13123 leg. (TLXM). Apurimac: Abancay, Auquibamba, route PE-3S, km 765, 13 $40^{\prime} 58^{\prime \prime}$ S, 72 $57^{\prime} 26^{\prime \prime}$ W, 2265 m a.s.1., leaves of Furcraea andina, 19 Apr. 2016, C. Lado 24542 leg. (MA-Fungi 91688); same data as for preceeding, twigs, C. Lado 24543 leg. (MA-Fungi 91689). La 


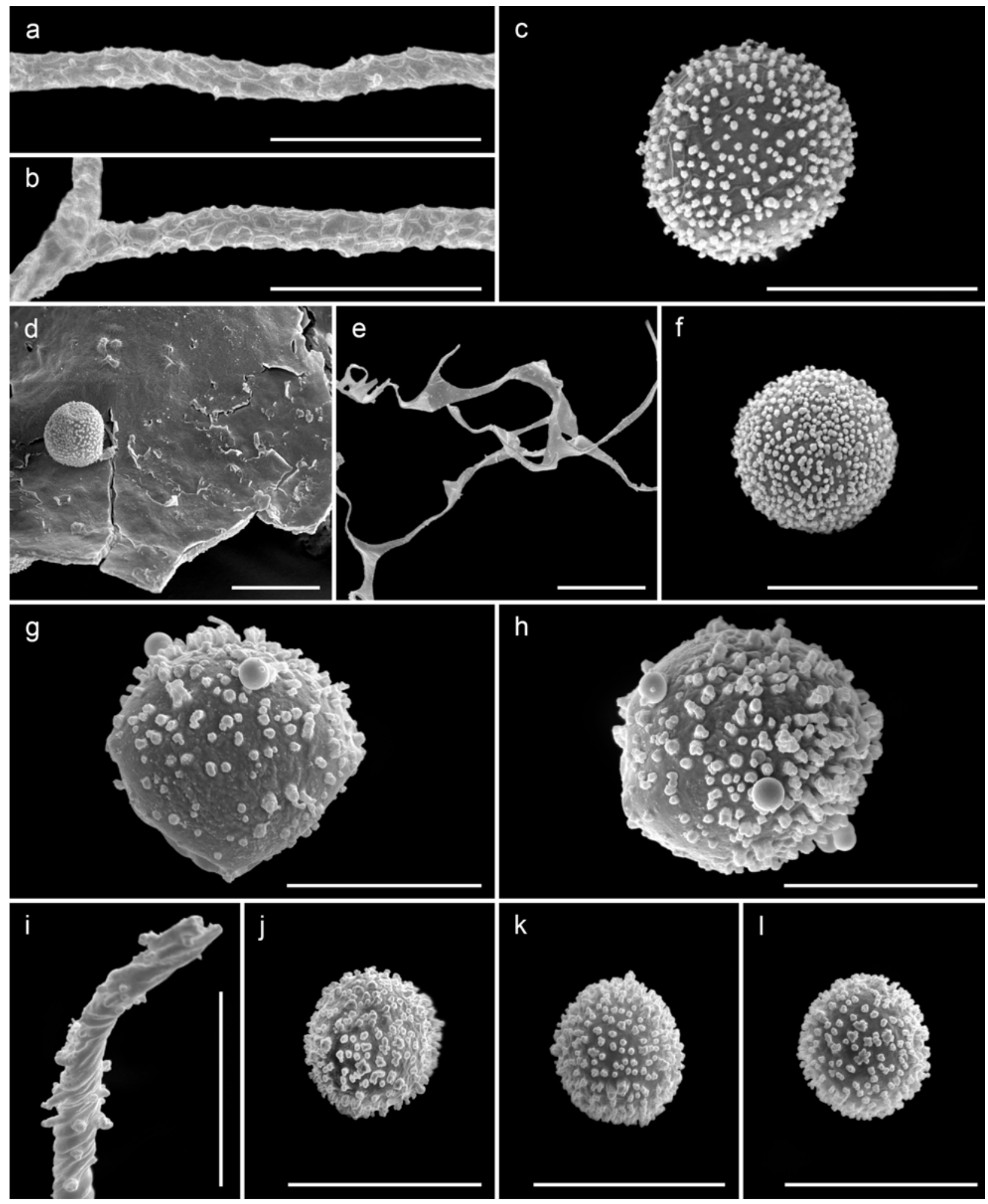

Fig. 7. A-C, Perichaena quadrata T.Macbr.: a, b, capillitium thread by SEM; c, spore by SEM. D-F, Physarum aeneum (Lister) R.E.Fr.: d, peridium by SEM; e, capillitium by SEM; f, spore by SEM. G, H, Physarum clavisporum G. Moreno \& al., spores by SEM with dispersed bacula, on the surface of the spore some calcic granules are attached. I-L, Trichia agaves (G. Moreno \& al.) Mosquera \& al.: i, detail of the ornamentation of the capillitial thread by SEM; $\mathbf{j}-\mathbf{l}$, spores by SEM. [a-c, C. Lado 22492 leg. (MA-Fungi 90992); d-f, C. Lado 22474 leg. (MA-Fungi 90973); g, h, C. Lado 22426 leg. (MA-Fungi 90921); i-1, C. Lado 22665 leg. (MA-Fungi 91004); scale bar: $10 \mu \mathrm{m}$. 
Libertad: Otuzco, Plazapalpa, route PE-10A, km 56, at the junction to Salpo, $07^{\circ} 59^{\prime} 19.1^{\prime \prime}$ S, $78^{\circ} 39^{\prime} 21.2^{\prime \prime}$ W, 1742 m a.s.l., leaves of Furcraea andina, 12 Apr. 2013, C. Lado 22447 leg. (MA-Fungi 90943); same data as for preceeding, C. Lado 22448 leg. (MA-Fungi 90944); same data as for preceeding, C. Lado 22450 leg. (MA-Fungi 90947); same data as for preceeding, wood, C. Lado 22451 leg. (MA-Fungi 90948); same data as for preceeding, litter and twigs of a herbaceous plant, C. Lado 22492 leg. (MA-Fungi 90992). Lima: Huarochirí, Matucana, Chacahuaro, route PE22, km 79, $11^{\circ} 49^{\prime} 07.1^{\prime \prime} \mathrm{S}, 76^{\circ} 21^{\prime} 37.3^{\prime \prime} \mathrm{W}, 2515 \mathrm{~m}$ a.s.1., leaves of Agave americana, 23 Sep. 2012, C. Lado 21728 leg. (MA-Fungi 90791); same data as for preceeding, C. Lado 21729 leg. (MA-Fungi 90793); same data as for preceeding, C. Lado 21733 leg. (MA-Fungi 90798); same data as for preceeding, C. Lado 21734 leg. (MA-Fungi 90800); same data as for preceeding, C. Lado 21735 leg. (MA-Fungi 90802); Yauyos, Calachota,

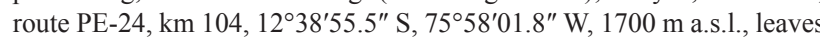
of Puya sp., moist chamber culture pH 7.38, 1 Oct. 2012, D. Wrigley de Basanta 3622 leg. (dwb); same data as for preceeding, moist chamber culture $\mathrm{pH}$ 7.39, D. Wrigley de Basanta 3636 leg. (dwb); same data as for preceeding, moist chamber culture $\mathrm{pH}$ 7.39, D. Wrigley de Basanta 3638 leg. (dwb); Canta, $6 \mathrm{~km}$ south of Canta, $11^{\circ} 29^{\prime} 11^{\prime \prime} \mathrm{S}, 76^{\circ} 38^{\prime} 38^{\prime \prime} \mathrm{W}$, 2406 m a.s.1., leaves of Furcraea andina, 18 May 2014, C. Lado 23642 leg. (MA-Fungi 91144).

Notes.-In the Neotropics it is only known from Argentina, Chile, Mexico, Panama and Peru (Lado \& al. 2011, 2013, 2014; EstradaTorres \& al. 2009; Lizárraga \& al. 2015a, 2015b). The delimitation between this species and Perichaena depressa was very difficult in the Peruvian material, since intermediate forms were common. Under this taxon we have grouped all the collections with depressed to pulvinate or globoid sporocarps, not markedly flattened as occurs in Perichaena depressa, with small dimensions of the sporotheca (diameter $0.1-0.5 \mathrm{~mm}$ vs. $0.5-1.5 \mathrm{~mm}$ in Perichaena depressa) and the capillitial threads (fig. 7a, b), mostly with reticulate ornamentation (very difficult to see in some cases), all these features are noted by Keller \& Eliasson (1992) as the differentiating characters of Perichaena quadrata.

\section{Perichaena vermicularis (Schwein.) Rostaf.}

Specimens examined.-PERU. Ancash: Huaylas, Caraz, Sucre, route PE-3N, km 665, 08 $56^{\prime} 12.7^{\prime \prime} \mathrm{S}, 77^{\circ} 50^{\prime} 30.8^{\prime \prime} \mathrm{W}, 2044 \mathrm{~m}$ a.s.l., cladode of Opuntia ficus-indica, 18 Apr. 2013, C. Lado 22786 leg. (MA-Fungi 91032). Arequipa: Arequipa, Yarabamba, Quequeña, $16^{\circ} 33^{\prime} 10^{\prime \prime} \mathrm{S}$, 71'27'32" W, $2510 \mathrm{~m}$ a.s.l., litter of Corryocactus brevistylus, 11 Apr. 2016, C. Lado 24218 leg. (MA-Fungi 91690); same data as for preceeding, plant litter, C. Lado 24224 leg. (MA-Fungi 91691). Lima:

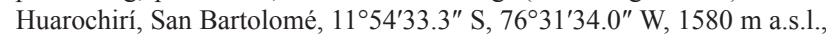
epidermis of Haageocereus acranthus, 22 Sep. 2012, C. Lado 21707 leg. (MA-Fungi 90766); same data as for preceeding, twigs, moist chamber culture pH 7.82, D. Wrigley de Basanta 3599 leg. (dwb); Huarochirí,

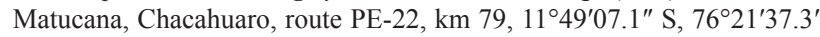
W, 2515 m a.s.l., litter of Espostoa lanata, moist chamber culture pH 7.97, 23 Sep. 2012, D. Wrigley de Basanta 3589 leg. (dwb); same data as for preceeding, moist chamber culture $\mathrm{pH} 7.83, D$. Wrigley de Basanta 3591 leg. (dwb); Yauyos, Yauyos, route PE-24, km 124, 12³1'56.7" S, $75^{\circ} 54^{\prime} 52.6^{\prime \prime} \mathrm{W}, 2180 \mathrm{~m}$ a.s.1., litter of Haageocereus acranthus, 1 Oct. 2012, C. Lado 22004 leg. (MA-Fungi 90824); same data as for preceeding, C. Lado 22007 leg. (MA-Fungi 90827); same data as for preceeding, litter of Espostoa lanata, C. Lado 22001 leg. (MA-Fungi 90821); same data as for preceeding, C. Lado 22011 leg. (MA-Fungi 90831); Yauyos, Yauyos,

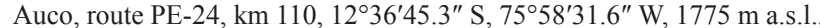
twigs, moist chamber culture pH 6.85, 1 Oct. 2012, S.L. Stephenson 28317 leg. (UARK); Yauyos, Calachota, route PE-24, km 104, $12^{\circ} 38^{\prime} 55.5^{\prime \prime} \mathrm{S}$, $75^{\circ} 58^{\prime} 01.8^{\prime \prime} \mathrm{W}, 1700 \mathrm{~m}$ a.s.1., inflorescence of Puya sp., moist chamber culture $\mathrm{pH} 8.28,1$ Oct. 2012, A. Estrada-Torres 12275 leg. (TLXM); same data as for preceeding, moist chamber culture $\mathrm{pH}$ 7.71, A. Estrada-Torres 12276 leg. (TLXM); same data as for preceeding, moist chamber culture pH 7.71, A. Estrada-Torres 12349 leg. (TLXM). Moquegua: Mariscal

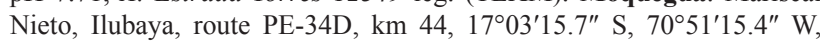
$2630 \mathrm{~m}$ a.s.l., litter of Weberbauerocereus weberbaueri, 7 Oct. 2012,
C. Lado 22152 leg. (MA-Fungi 90889); same data as for preceeding, $C$. Lado 22155 leg. (MA-Fungi 90893). Tacna: Palca, Huanune, route PE-

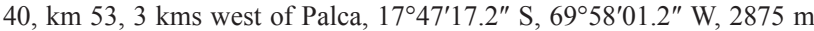
a.s.l., litter of Corryocactus brevistylus, 5 Oct. 2012, C. Lado 22110 leg. (MA-Fungi 90843); same data as for preceeding, litter of Haageocereus sp., C. Lado 22114 leg. (MA-Fungi 90849); same data as for preceeding, litter of Cumulopuntia corotilla, C. Lado 22117 leg. (MA-Fungi 90853); same data as for preceeding, litter of Haageocereus sp., C. Lado 22118 leg. (MA-Fungi 90856); Pachia, Los Olivares, route PE-40, km 43, $13 \mathrm{~km}$ west of Palca, $17^{\circ} 48^{\prime} 51.5^{\prime \prime} \mathrm{S}, 70^{\circ} 00^{\prime} 33.3^{\prime \prime} \mathrm{W}, 2345 \mathrm{~m}$ a.s.l., litter of Haageocereus sp., 5 Oct. 2012, C. Lado 22121 leg. (MA-Fungi 90859); same data as for preceeding, C. Lado 22122 leg. (MA-Fungi 90861); same data as for preceeding, litter of Browningia candelaris, C. Lado 22130 leg. (MA-Fungi 90869).

Notes.-In Peru it was previously reported from Loreto (Wrigley de Basanta \& al. 2008a), Madre de Dios (Rojas \& Stephenson 2013) and the arid zones of Ayacucho, Arequipa, Lima, Ica, La Libertad, Cajamarca, Ancash and Piura (Lado \& al. 2016).

\section{Physarum aeneum (Lister) R.E.Fr. Fig. 7d-f.}

Specimens examined.-PERU. La Libertad: Otuzco, Plazapalpa, route PE-10A, km 56, at the junction to Salpo, 07 $59^{\prime} 19.1^{\prime \prime} \mathrm{S}, 78^{\circ} 39^{\prime} 21.2^{\prime \prime} \mathrm{W}$, 1742 m a.s.l., leaves of Puya sp., 12 Apr. 2013, C. Lado 22474 leg. (MAFungi 90973).

Notes.-This is the second record of the species in Peru, previously reported by Lado \& al. (2016) from Cajamarca. The collection examined has the typical cartilaginous outer peridium (fig. 7d), but the capillitium has very scanty lime nodes, and these are flat and almost limeless (fig. 7e). Also the spores by SEM are more or less uniformly warted, without clusters of larger ones (fig. 7f), as noted Farr (1976) for Neotropical specimens.

\section{Physarum album (Bull.) Chevall.}

Specimens examined.-PERU. Ancash: Huaylas, Caraz, Sucre, route PE-3N, km 665, 08 56'12.7" S, 7750'30.8" W, 2044 m a.s.1., twigs, 18 Apr. 2013, C. Lado 22781 leg. (MA-Fungi 91027). La Libertad: Otuzco, Plazapalpa, route PE-10A, km 56, at the junction to Salpo, 0759'19.1" S, 78³9'21.2" W, 1742 m a.s.1., leaves of Puya sp., 12 Apr. 2013, C. Lado 22461 leg. (MA-Fungi 90959); same data as for preceeding, C. Lado 22462 leg. (MA-Fungi 90960); same data as for preceeding, C. Lado 22465 leg. (MA-Fungi 90963); same data as for preceeding, C. Lado 22467 leg. (MA-Fungi 90967); same data as for preceeding, C. Lado 22471 leg. (MA-Fungi 90970); same data as for preceeding, C. Lado 22478 leg. (MA-Fungi 90977); same data as for preceeding, C. Lado 22479 leg. (MA-Fungi 90978). Piura: Huancabamba, route PE-04E, km 49, Abra Porcuya, 550'28" S, 79²9'22" W, $2005 \mathrm{~m}$ a.s.1., leaf litter and twigs, 10 May 2014, C. Lado 23460 leg. (MA-Fungi 91080); same data as for preceeding, branches, C. Lado 23472 leg. (MA-Fungi 91092); same data as for preceeding, twigs, C. Lado 23480 leg. (MA-Fungi 91871).

Notes.-In Peru it was previously reported from Madre de Dios and Cajamarca (Rojas \& al. 2011; Rojas \& Stephenson 2013; Lado \& al. 2016).

\section{Physarum atacamense D.Wrigley, Lado \& Estrada}

Specimens examined.-PERU. Lima: Yauyos, Calachota, route PE-24, $\mathrm{km} \mathrm{104,} 12^{\circ} 38^{\prime} 55.5^{\prime \prime} \mathrm{S}, 75^{\circ} 58^{\prime} 01.8^{\prime \prime} \mathrm{W}, 1700$ m a.s.l., leaves of Puya sp., moist chamber culture pH 7.38, 1 Oct. 2012, D. Wrigley de Basanta 3621 leg. (dwb).

Notes.-This species, described from the Atacama Desert (Chile), has a wide and frequent distribution in the coastal arid lands of Peru (Lado \& al. 2016), but surprisingly it is much less common in the arid bordering zones of the 'cardonal'. 


\section{Physarum bitectum G.Lister}

Specimens examined.-PERU. Lima: Canta, $6 \mathrm{~km}$ south of Canta, $11^{\circ} 29^{\prime} 11^{\prime \prime} \mathrm{S}, 76^{\circ} 38^{\prime} 38^{\prime \prime} \mathrm{W}, 2406 \mathrm{~m}$ a.s.1., leaves of Furcraea andina, 18 May 2014, C. Lado 23640 leg. (MA-Fungi 91142).

Notes.-In Peru it was previously known only from Ica (Lado \& al. 2016).

\section{* Physarum bivalve Pers.}

Specimens examined.-PERU. Tacna: Palca, Huanune, route PE-40, km 53, $3 \mathrm{~km}$ west of Palca, 1747'17.2" S, 6958'01.2" W, $2875 \mathrm{~m}$ a.s.1., ground litter, moist chamber culture $\mathrm{pH} 4.96,5$ Oct. 2012, S.L. Stephenson 29089 leg. (UARK).

Notes.-It is a species widely distributed throughout the Neotropics. From Peru, Farr (1976: 125) reported a collection, without locality, preserved at BPI. Our search of the database of this herbarium did not give a positive result. In any case, our specimen, confirms the presence of this species in the country.

\section{Physarum bogoriense Racib.}

Specimens examined.-PERU. Ancash: Huaylas, Caraz, Pueblo Libre,

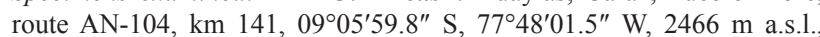
leaves of Puya angusta, 20 Apr. 2013, C. Lado 22941 leg. (MA-Fungi 91044); same data as for preceeding, C. Lado 22942 leg. (MA-Fungi 91045); same data as for preceeding, leaf litter and twigs, C. Lado 22943 leg. (MA-Fungi 91046); same data as for preceeding, leaf litter, C. Lado 22944 leg. (MA-Fungi 91047); Bolognesi, Cajacay, route PE-16, km 96, $10^{\circ} 08^{\prime} 03.2^{\prime \prime} \mathrm{S}, 7^{\circ} 24^{\prime} 03.4^{\prime \prime} \mathrm{W}, 2935 \mathrm{~m}$ a.s.1., litter of a herbaceous plant, 24 Apr. 2013, C. Lado 23174 leg. (MA-Fungi 91062). Apurimac: Abancay, $5 \mathrm{~km}$ from the Cunyac bridge, route PE-3S, Km 864, 133' $01^{\prime \prime}$ S, 72³6'43" W, 1954 m a.s.1., leaves, 21 Apr. 2016, C. Lado 24609 leg. (MA-Fungi 91692). Huancavelica: Tayacaja, route PE-3S, km 198, Izcuchaca, $7 \mathrm{~km}$ south of Izcuchaca, 12 $31^{\prime} 17^{\prime \prime} \mathrm{S}, 74^{\circ} 56^{\prime} 50^{\prime \prime} \mathrm{W}, 2840 \mathrm{~m}$ a.s.l., bryophytes, 25 Apr. 2017, C. Lado 25239 leg. (MA-Fungi 91693); same data as for preceeding, C. Lado 25241 leg. (MA-Fungi 91694). La Libertad: Otuzco, Plazapalpa, route PE-10A, km 56, at the junction to Salpo, 0759'19.1" S, 78³9'21.2" W, $1742 \mathrm{~m}$ a.s.l., litter and twigs of a herbaceous plant, 12 Apr. 2013, C. Lado 22433 leg. (MA-Fungi 90928).

Notes.-In Peru it was previously reported from Ancash, Cajamarca, Huánuco and Loreto (Wrigley de Basanta \& al. 2008a; Lado \& al. 2016).

\section{Physarum cinereum (Batsch) Pers.}

Specimens examined.-PERU. Ancash: Pallasca, Ancos, route PE-3N,

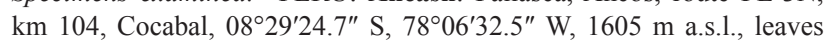
of Puya sp., 11 Apr. 2013, C. Lado 22406 leg. (MA-Fungi 90910). La Libertad: Otuzco, Plazapalpa, route PE-10A, km 56, at the junction to Salpo, 0759'19.1" S, 78 $39^{\prime} 21.2^{\prime \prime}$ W, $1742 \mathrm{~m}$ a.s.1., leaves of Puya sp., 12 Apr. 2013, C. Lado 22456 leg. (MA-Fungi 90954). Piura: Huancabamba, route PE-04E, km 49, Abra Porcuya, 550'28" S, 79²9'22" W, 2005 m a.s.1., twigs, 10 May 2014, C. Lado 23466 leg. (MA-Fungi 91086).

Notes.-In Peru it was previously reported from the arid coastal lands of Arequipa and Lima (Lado \& al. 2016).

\section{Physarum clavisporum G.Moreno, A.Sánchez,}

\section{A.Castillo \& Illana. Fig. $7 \mathrm{~g}$, h.}

Specimens examined.-PERU. Ancash: Bolognesi, Cajacay, route PE-16,

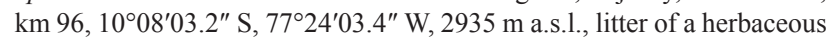
plant, 24 Apr. 2013, C. Lado 23169 leg. (MA-Fungi 91058); same data as for preceeding, C. Lado 23172 leg. (MA-Fungi 91060); Bolognesi,

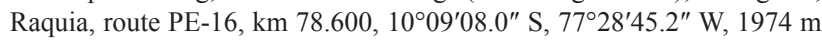
a.s.1., leaves of Puya ferruginea, 24 Apr. 2013, C. Lado 23179 leg. (MAFungi 91067). Huancavelica: Tayacaja, route PE-3S, km 198, Izcuchaca, $7 \mathrm{~km}$ south of Izcuchaca, $12^{\circ} 31^{\prime} 17^{\prime \prime} \mathrm{S}, 74^{\circ} 56^{\prime} 50^{\prime \prime} \mathrm{W}, 2840 \mathrm{~m}$ a.s.1., leaves of Puya sp., 25 Apr. 2017, C. Lado 25251 leg. (MA-Fungi 91695); same data as for preceeding, twigs, C. Lado 25252 leg. (MA-Fungi 91696). La Libertad: Otuzco, Otuzco, route PE-10A, km 70, near the junction to Otuzco and Agalpampa, 07 $55^{\prime} 40.5^{\prime \prime}$ S, 78 $34^{\prime} 43.6^{\prime \prime}$ W, 2525 m a.s.1., litter of Tillandsia sp., 12 Apr. 2013, C. Lado 22422 leg. (MA-Fungi 90915); same data as for preceeding, C. Lado 22424 leg. (MA-Fungi 90919); Otuzco, Plazapalpa, route PE-10A, km 56, at the junction to Salpo, $07^{\circ} 59^{\prime} 19.1^{\prime \prime} \mathrm{S}, 78^{\circ} 39^{\prime} 21.2^{\prime \prime} \mathrm{W}, 1742 \mathrm{~m}$ a.s.1., litter and twigs of a herbaceous plant, 12 Apr. 2013, C. Lado 22426 leg. (MA-Fungi 90921); same data as for preceeding, C. Lado 22427 leg. (MA-Fungi 90922); same data as for preceeding, C. Lado 22430 leg. (MA-Fungi 90925); same data as for preceeding, C. Lado 22431 leg. (MA-Fungi 90926); same data as for preceeding, C. Lado 22432 leg. (MA-Fungi 90927); same data as for preceeding, C. Lado 22435 leg. (MA-Fungi 90930); same data as for preceeding, C. Lado 22438 leg. (MA-Fungi 90934); same data as for preceeding, C. Lado 22441 leg. (MA-Fungi 90937); same data as for preceeding, flower stalk of Puya sp., C. Lado 22443 leg. (MAFungi 90939); same data as for preceeding, leaves of Furcraea andina, C. Lado 22445 leg. (MA-Fungi 90941); same data as for preceeding, litter and twigs of a herbaceous plant, C. Lado 22489 leg. (MA-Fungi 90989). Lima: Yauyos, Yauyos, Auco, route PE-24, km 110, 12³6'45.3" S, 75 58'31.6" W, $1775 \mathrm{~m}$ a.s.1., litter of Tillandsia sp., moist chamber culture pH 5.26, 1 Oct. 2012, D. Wrigley de Basanta 3631 leg. (dwb); same data as for preceeding, moist chamber culture $\mathrm{pH} 6.54$, D. Wrigley de Basanta 3632 leg. (dwb).

Notes.-In Peru it was previously reported from Ancash, Cajamarca, La Libertad and Piura (Lado \& al. 2016). The spores of our collections have an ornamentation, by SEM (fig. $7 \mathrm{~g}, \mathrm{~h}$ ), which coincides with those mentioned by Lado \& al. (2016) for material from the Peruvian coastal desert, but slightly differ from that illustrated by Moreno \& al. (2009) of the holotype of this species, since the bacula are more dense, the apex is not widened and warty to coralloid, and the spore surface is not covered by tiny densely and regularly distributed warts.

\section{Physarum compressum Alb. \& Schwein.}

Specimens examined.-PERU. Ancash: Bolognesi, Raquia, route PE16, km 78.600, $10^{\circ} 09^{\prime} 08.0^{\prime \prime} \mathrm{S}, 77^{\circ} 28^{\prime} 45.2^{\prime \prime} \mathrm{W}, 1974 \mathrm{~m}$ a.s.1., leaves of Puya ferruginea, 24 Apr. 2013, C. Lado 23180 leg. (MA-Fungi 91068).

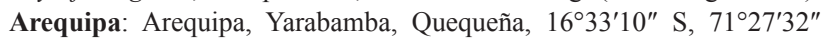
W, 2510 m a.s.1., litter of Corryocactus brevistylus, 11 Apr. 2016, C. Lado 24217 leg. (MA-Fungi 91697); same data as for preceeding, $C$. Lado 24219 leg. (MA-Fungi 91698); same data as for preceeding, $C$. Lado 24220 leg. (MA-Fungi 91699); same data as for preceeding, $C$. Lado 24221 leg. (MA-Fungi 91700). Lima: Huarochirí, San Bartolomé, $11^{\circ} 54^{\prime} 33.3^{\prime \prime} \mathrm{S}, 76^{\circ} 31^{\prime} 34.0^{\prime \prime} \mathrm{W}, 1580 \mathrm{~m}$ a.s.1., cactus, moist chamber culture pH 8.29, 22 Sep. 2012, S.L. Stephenson 30092 leg. (UARK); Yauyos, Yauyos, route PE-24, km 124, 12³1'56.7" S, 7554'52.6" W, $2180 \mathrm{~m}$ a.s.1., litter of Haageocereus acranthus, 1 Oct. 2012, C. Lado 22003 leg. (MA-Fungi 90823); Canta, $2 \mathrm{~km}$ south of Canta, 11 ${ }^{\circ} 28^{\prime} 30^{\prime \prime}$ S, 76³7'45" W, $2700 \mathrm{~m}$ a.s.l., cladode of Opuntia sp., 18 May 2014, C. Lado 23622 leg. (MA-Fungi 91124). Piura: Huancabamba, route PE04E, km 49, Abra Porcuya, 550'28" S, 79²9'22" W, 2005 m a.s.l., twigs, 10 May 2014, C. Lado 23451 leg. (MA-Fungi 91071). Tacna: Pachia, Los Olivares, route PE-40, km 43, $13 \mathrm{kms}$ west of Palca, 1748'51.5" S, $70^{\circ} 00^{\prime} 33.3^{\prime \prime} \mathrm{W}, 2345 \mathrm{~m}$ a.s.1., litter of Browningia candelaris, 5 Oct. 2012, C. Lado 22130 leg. (MA-Fungi 90870).

Notes.-In Peru it was previously reported from Ancash, Cajamarca, Lima, Loreto, Madre de Dios and Tumbes (Wrigley de Basanta \& al. 2008a; Rojas \& Stephenson 2013; Lado \& al. 2016). The collection C. Lado 24221 leg. (MA-Fungi 91700) shows a strongly lime almost badhamioid capillitium, but the rest of the characters agree with the concept of Physarum compressum, for this reason we have included it under this binomen. 


\section{Physarum flavicomum Berk.}

Specimens examined.-PERU. Piura: Huancabamba, route PE-04E, km 49, Abra Porcuya, 550'28' S, 79²9'22' W, 2005 m a.s.1., twigs, 10 May 2014, C. Lado 23455 leg. (MA-Fungi 91075).

Notes.-Another species widely distributed throughout the Neotropics. In Peru it was previously reported only from the tropical forests of Madre de Dios (Rojas \& Stephenson 2013).

\section{Physarum globuliferum (Bull.) Pers.}

Specimens examined.-PERU. La Libertad: Otuzco, Plazapalpa, route PE-10A, km 56, at the junction to Salpo, 0759'19.1" S, 78³9'21.2" W, $1742 \mathrm{~m}$ a.s.1., litter and twigs of a herbaceous plant, 12 Apr. 2013, C. Lado 22425 leg. (MA-Fungi 90920); same data as for preceeding, $C$. Lado 22429 leg. (MA-Fungi 90924).

Notes.-In Peru it was previously reported from Loreto (Wrigley de Basanta \& al. 2008a).

\section{Physarum javanicum Racib.}

Specimens examined.-PERU. Ancash: Bolognesi, Raquia, route PE-

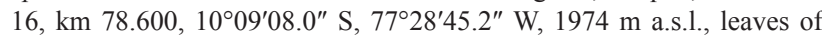
Puya ferruginea, 24 Apr. 2013, C. Lado 23175 leg. (MA-Fungi 91063). Piura: Huancabamba, route PE-04E, km 49, Abra Porcuya, 550'28" S, 79²9'22" W, 2005 m a.s.l., twigs, 10 May 2014, C. Lado 23458 leg. (MA-Fungi 91078); same data as for preceeding, branches, C. Lado 23473 leg. (MA-Fungi 91093).

Notes.-A species originally described from Java that is widely distributed throughout the Neotropics. In Peru it was previously reported from the arid lands of Ancash, Arequipa and Cajamarca (Lado \& al. 2016).

\section{* Physarum leucopus Link}

Specimens examined.-PERU. Lima: Canta, $2 \mathrm{~km}$ south of Canta, $11^{\circ} 28^{\prime} 30^{\prime \prime} \mathrm{S}, 7^{\circ} 37^{\prime} 45^{\prime \prime} \mathrm{W}, 2700 \mathrm{~m}$ a.s.1., cladode of Opuntia sp., 18 May 2014, C. Lado 23627 leg. (MA-Fungi 91129).

Notes.-A species widely distributed throughout the Neotropics, but not previously reported from Peru.

\section{Physarum licheniforme (Schwein.) Lado}

Specimens examined.-PERU. Arequipa: Arequipa, Yarabamba, Quequeña, 16 ${ }^{\circ} 33^{\prime} 10^{\prime \prime}$ S, 71 $27^{\prime} 32^{\prime \prime} \mathrm{W}, 2510 \mathrm{~m}$ a.s.l., leaves of Puya cylindrica, 11 Apr. 2016, C. Lado 24211 leg. (MA-Fungi 91702); same data as for preceeding, C. Lado 24212 leg. (MA-Fungi 91703).

Notes.-In Peru it was previously reported from Cajamarca (Lado \& al. 2016).

\section{* Physarum megalosporum T.Macbr.}

Specimens examined.-PERU. Ancash: Pallasca, Ancos, route PE-3N,

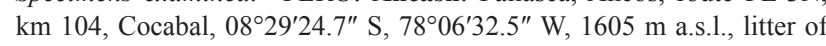
Haageocereus sp., 11 Apr. 2013, C. Lado 22399 leg. (MA-Fungi 87908); Huaraz, Pariacoto, route PE-14, km 79, 09³2'16.1" S, 7746'07.4" W, 2569 m a.s.l., leaves of Agave americana, 17 Apr. 2013, C. Lado 22668 leg. (MA-Fungi 91006); Huaylas, Caraz, Pueblo Libre, route AN-104, km 141, $09^{\circ} 05^{\prime} 59.8^{\prime \prime}$ S, 7748'01.5" W, 2466 m a.s.1., leaves of Agave americana, 20 Apr. 2013, C. Lado 22934 leg. (MA-Fungi 91037); same data as for preceeding, leaves of Puya angusta, C. Lado 22940 leg. (MAFungi 91043). Huancavelica: Tayacaja, route PE-3S, km 198, Izcuchaca, $7 \mathrm{~km}$ south of Izcuchaca, 12 ${ }^{\circ} 31^{\prime} 17^{\prime \prime} \mathrm{S}, 74^{\circ} 56^{\prime} 50^{\prime \prime} \mathrm{W}, 2840 \mathrm{~m}$ a.s.1., bryophytes, 25 Apr. 2017, C. Lado 25245 leg. (MA-Fungi 91704). Lima:

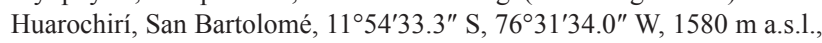
twigs, 22 Sep. 2012, C. Lado 21707 leg. (MA-Fungi 90767); Yauyos,
Yauyos, route PE-24, km 124, 12³1'56.7" S, 7554'52.6" W, $2180 \mathrm{~m}$ a.s.1., wood, 1 Oct. 2012, C. Lado 22000 leg. (MA-Fungi 90820).

Notes.-In South America it was only previously known from the arid lands of the north of Argentina and Chile (Lado \& al. 2007a, 2011). Cavalcanti (2002) also reported this species from Pernambuco, in the east of Brazil, probably linked to the arid areas of this state. These are the first records for Peru.

\section{Physarum melleum (Berk. \& Broome) Massee}

Specimens examined.-PERU. Ancash: Huaylas, Caraz, Sucre, route PE$3 \mathrm{~N}, \mathrm{~km} 665,08^{\circ} 56^{\prime} 12.7^{\prime \prime} \mathrm{S}, 7^{\circ} 50^{\prime} 30.8^{\prime \prime} \mathrm{W}, 2044 \mathrm{~m}$ a.s.1., twigs, $18 \mathrm{Apr}$. 2013, C. Lado 22782 leg. (MA-Fungi 91028). Cusco: Anta, Limatambo,

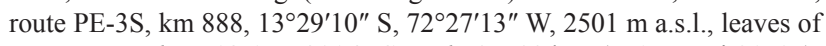
Furcraea andina, 18 Apr. 2016, C. Lado 24499 leg. (MA-Fungi 91705). La Libertad: Otuzco, Plazapalpa, route PE-10A, km 56, at the junction to Salpo, 0759'19.1" S, 78³9'21.2" W, $1742 \mathrm{~m}$ a.s.1., litter of a herbaceous plant and twigs, 12 Apr. 2013, C. Lado 22434 leg. (MA-Fungi 90929); same data as for preceeding, C. Lado 22435 leg. (MA-Fungi 90931); same data as for preceeding, C. Lado 22437 leg. (MA-Fungi 90933); same data as for preceeding, C. Lado 22439 leg. (MA-Fungi 90935); same data as for preceeding, C. Lado 22440 leg. (MA-Fungi 90936).

Notes.-In Peru it was previously reported from Cajamarca and Loreto (Wrigley de Basanta \& al. 2008a; Lado \& al. 2016).

\section{Physarum notabile T.Macbr.}

Specimens examined.-PERU. Ancash: Huaylas, Caraz, Sucre, route PE-3N, km 665, 08 56'12.7" S, 7750'30.8” W, $2044 \mathrm{~m}$ a.s.1., twigs, 18 Apr. 2013, C. Lado 22780 leg. (MA-Fungi 91026). Lima: Huarochirí, San Bartolomé, $11^{\circ} 54^{\prime} 33.3^{\prime \prime}$ S, $76^{\circ} 31^{\prime} 34.0^{\prime \prime} \mathrm{W}, 1580 \mathrm{~m}$ a.s.l., twigs, moist chamber culture pH 6.43, 22 Sep. 2012, S.L. Stephenson 30095 leg. (UARK); same data as for preceeding, moist chamber culture $\mathrm{pH} 6.38$, S.L. Stephenson 30122 leg. (UARK); Yauyos, Yauyos, route PE-24, km $124,12^{\circ} 31^{\prime} 56.7^{\prime \prime} \mathrm{S}, 75^{\circ} 54^{\prime} 52.6^{\prime \prime} \mathrm{W}, 2180 \mathrm{~m}$ a.s.1., twigs, moist chamber culture pH 6.1, 1 Oct. 2012, S.L. Stephenson 28964 leg. (UARK); Yauyos, Yauyos, Auco, route PE-24, km 110, 12³6'45.3" S, 7558'31.6" W, $1775 \mathrm{~m}$ a.s.1., twigs, moist chamber culture $\mathrm{pH}$ 6.85, 1 Oct. 2012, S.L. Stephenson 28318 leg. (UARK); same data as for preceeding, moist chamber culture pH 6.76, S.L. Stephenson 28435 leg. (UARK); Yauyos, Calachota, route PE-24, km 104, 12 $38^{\prime} 55.5^{\prime \prime} \mathrm{S}, 75^{\circ} 58^{\prime} 01.8^{\prime \prime} \mathrm{W}, 1700 \mathrm{~m}$ a.s.l., leaves of Puya sp., 1 Oct. 2012, C. Lado 22019 leg. (MA-Fungi 90839).

Notes.-In Peru it was previously reported from the arid lands of Arequipa, La Libertad, Lima and Piura (Lado \& al. 2016).

\section{* Physarum ovisporum G.Lister}

Specimens examined.-PERU. Ancash: Huaraz, Pariacoto, route PE-14, km 79, 09'32'16.1" S, 7746'07.4" W, 2569 m a.s.l., leaves of Agave americana, 17 Apr. 2013, C. Lado 22671 leg. (MA-Fungi 91011). Lima: Canta, $6 \mathrm{~km}$ south of Canta, $11^{\circ} 29^{\prime} 11^{\prime \prime} \mathrm{S}, 76^{\circ} 38^{\prime} 38^{\prime \prime} \mathrm{W}, 2406 \mathrm{~m}$ a.s.1., leaves of Furcraea andina, 18 May 2014, C. Lado 23643 leg. (MA-Fungi 91145); same data as for preceeding, C. Lado 23644 leg. (MA-Fungi 91146).

Notes.-In South America it was previously known from Argentina, Brazil, Chile and Colombia, but not previously reported from Peru.

\section{Physarum pusillum (Berk. \& M.A.Curtis) G. Lister}

Specimens examined.-PERU. Ancash: Huaylas, Caraz, Sucre, route PE-3N, km 665, 08 $56^{\prime} 12.7^{\prime \prime} \mathrm{S}, 77^{\circ} 50^{\prime} 30.8^{\prime \prime} \mathrm{W}, 2044 \mathrm{~m}$ a.s.1., litter of Armatocereus sp., 18 Apr. 2013, C. Lado 22783 leg. (MA-Fungi 91029); same data as for preceeding, C. Lado 22787 leg. (MA-Fungi 91034); Huaylas, Caraz, Pueblo Libre, route AN-104, km 141, 0905'59.8" S, $77^{\circ} 48^{\prime} 01.5^{\prime \prime} \mathrm{W}, 2466 \mathrm{~m}$ a.s.l., inflorescence of Puya angusta, 20 
Apr. 2013, C. Lado 22945 leg. (MA-Fungi 91048); same data as for preceeding, C. Lado 22946 leg. (MA-Fungi 91049); same data as for preceeding, moist chamber culture $\mathrm{pH} 8.12$, A. Estrada-Torres 13018 leg. (TLXM); Huari, $21 \mathrm{~km}$ from Huari towards San Marcos, $9^{\circ} 28^{\prime} 02^{\prime \prime} \mathrm{S}$, 77 $08^{\prime} 37^{\prime \prime}$ W, 2827 m a.s.1., branch of Baccharis latifolia, 21 May 2014 C. Lado 23728 leg. (MA-Fungi 91158). Arequipa: Arequipa, Yarabamba, Quequeña, $16^{\circ} 33^{\prime} 10^{\prime \prime}$ S, $71^{\circ} 27^{\prime} 32^{\prime \prime} \mathrm{W}, 2510 \mathrm{~m}$ a.s.l., leaf litter of Puya cylindrica, moist chamber culture $\mathrm{pH}$ 7.92, 11 Apr. 2016, D. Wrigley de Basanta 3824 leg. (dwb). Cajamarca: Cajamarca, San Juan, route PE-

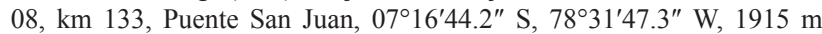
a.s.l., inflorescence and fruits of Puya sp., 15 Apr. 2013, C. Lado 22603 leg. (MA-Fungi 91000). Huancavelica: Tayacaja, route PE-3S, km 198, Izcuchaca, $7 \mathrm{~km}$ south of Izcuchaca, 12 $31^{\prime} 17^{\prime \prime} \mathrm{S}, 74^{\circ} 56^{\prime} 50^{\prime \prime} \mathrm{W}, 2840 \mathrm{~m}$ a.s.1., twigs, 25 Apr. 2017, C. Lado 25255 leg. (MA-Fungi 91706). Lima:

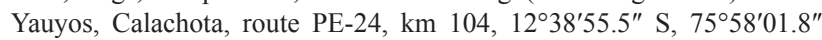
W, $1700 \mathrm{~m}$ a.s.l., inflorescence of Puya sp., moist chamber culture $\mathrm{pH}$ 8.28, 1 Oct. 2012, A. Estrada-Torres 12269 leg. (TLXM); Canta, 6 km south of Canta, $11^{\circ} 29^{\prime} 11^{\prime \prime} \mathrm{S}, 76^{\circ} 38^{\prime} 38^{\prime \prime} \mathrm{W}, 2406 \mathrm{~m}$ a.s.l., leaves of Furcraea andina, 18 May 2014, C. Lado 23645 leg. (MA-Fungi 91147) Piura: Huancabamba, route PE-04E, km 49, Abra Porcuya, 5 50 $50^{\prime 2} 8^{\prime \prime} \mathrm{S}$, 79²9'22" W, 2005 m a.s.l., twigs, 10 May 2014, C. Lado 23462 leg. (MA-Fungi 91082); same data as for preceeding, branches, C. Lado 23469 leg. (MA-Fungi 91089); same data as for preceeding, C. Lado 23483 leg. (MA-Fungi 91103); same data as for preceeding, leaf litter and twigs, C. Lado 23493 leg. (MA-Fungi 91113).

Notes.- It is widely distributed throughout the Neotropics. In Peru it was previously reported from Ancash, Arequipa, Cajamarca, Lima, Loreto and Madre de Dios (Wrigley de Basanta \& al. 2008a; Rojas \& Stephenson 2013; Lado \& al. 2016).

\section{Physarum spectabile Nann.-Bremek., Lado \& G.Moreno}

Specimens examined.-PERU. Ancash: Huaylas, Caraz, Sucre, route PE-3N, km 665, 08 $56^{\prime} 12.7^{\prime \prime} \mathrm{S}, 77^{\circ} 50^{\prime} 30.8^{\prime \prime} \mathrm{W}, 2044 \mathrm{~m}$ a.s.1., cladode of Opuntia ficus-indica, 18 Apr. 2013, C. Lado 22785 leg. (MAFungi 91031); Huaylas, Caraz, Pueblo Libre, route AN-104, km 141, $09^{\circ} 05^{\prime} 59.8^{\prime \prime}$ S, $77^{\circ} 48^{\prime} 01.5^{\prime \prime}$ W, $2466 \mathrm{~m}$ a.s.l., litter of Armatocereus mataranus, 20 Apr. 2013, C. Lado 22952 leg. (MA-Fungi 91056); same data as for preceeding, inflorescence of Puya angusta, moist chamber culture $\mathrm{pH}$ 7.76, A. Estrada-Torres 13101 leg. (TLXM). Huancavelica: Angaraes, route PE-26B, km 158, $4 \mathrm{~km}$ west of Laramate, $13^{\circ} 01^{\prime} 48^{\prime \prime}$ S, $74^{\circ} 23^{\prime} 48^{\prime \prime} \mathrm{W}, 2890 \mathrm{~m}$ a.s.l., cladode of Opuntia ficus-indica, $22 \mathrm{Apr}$ 2017, C. Lado 25039 leg. (MA-Fungi 91707); Tayacaja, route PE-3S, $\mathrm{km} 193$, Izcuchaca, $2 \mathrm{~km}$ south of Izcuchaca, 12 $2^{\circ} 30^{\prime} 23^{\prime \prime} \mathrm{S}, 74^{\circ} 58^{\prime} 40^{\prime \prime} \mathrm{W}$ 2856 m a.s.l., leaves of Agave americana, 25 Apr. 2017, C. Lado 25260 leg. (MA-Fungi 91708). Lima: Huarochirí, San Bartolomé, 11 ${ }^{\circ} 54^{\prime} 33.3^{\prime \prime}$ S, 76 $31^{\circ} 34.0^{\prime \prime} \mathrm{W}, 1580 \mathrm{~m}$ a.s.1., epidermis of Haageocereus acranthus, moist chamber culture pH 7.52, 22 Sep. 2012, D. Wrigley de Basanta 3596 leg. (dwb); same data as for preceeding, moist chamber culture $\mathrm{pH}$ 8.22, D. Wrigley de Basanta 3608 leg. (dwb); same data as for preceeding, moist chamber culture $\mathrm{pH} 7.82, \mathrm{D}$. Wrigley de Basanta 3610 leg. (dwb);

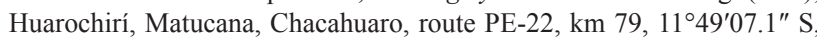
76 $21^{\prime} 37.3^{\prime \prime}$ W, 2515 m a.s.1., leaves of Agave americana, 23 Sep. 2012, C. Lado 21717 leg. (MA-Fungi 90778); same data as for preceeding, C. Lado 21719 leg. (MA-Fungi 90780); same data as for preceeding, C. Lado 21725 leg. (MA-Fungi 90787); same data as for preceeding, C. Lado 21737 leg. (MA-Fungi 90805); same data as for preceeding, C. Lado 21740 leg. (MA-Fungi 90808); same data as for preceeding, C. Lado 21741 leg. (MA-Fungi 90810); same data as for preceeding, C. Lado 21744 leg. (MA-Fungi 90814); same data as for preceeding, C. Lado 21748 leg. (MA-Fungi 90818); Huarochirí, San Mateo, route

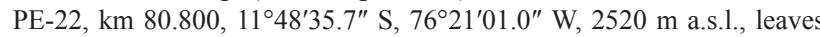
of Puya sp., moist chamber culture pH 7.28, 23 Sep. 2012, D. Wrigley de Basanta 3577 leg. (dwb); Yauyos, Yauyos, route PE-24, km 124 $12^{\circ} 31^{\prime} 56.7^{\prime \prime} \mathrm{S}, 75^{\circ} 54^{\prime} 52.6^{\prime \prime} \mathrm{W}, 2180$ m a.s.l., litter of Espostoa lanata, 1 Oct. 2012, C. Lado 22012 leg. (MA-Fungi 90832). Moquegua: Mariscal

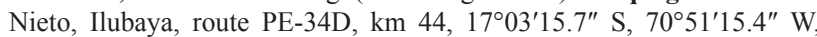
$2630 \mathrm{~m}$ a.s.l., litter of Weberbauerocereus weberbauerii, moist chamber culture pH 8.28, 7 Oct. 2012, D. Wrigley de Basanta 3580 leg. (dwb); same data as for preceeding, C. Lado 22149 leg. (MA-Fungi 90887); same data as for preceeding, C. Lado 22152 leg. (MA-Fungi 90890); same data as for preceeding, litter of Corryocactus brevistylus, C. Lado 22160 leg. (MA-Fungi 90898). Tacna: Palca, Huanune, route PE-40, km

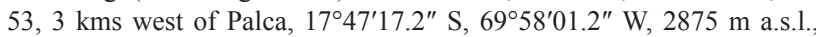
litter of Corryocactus brevistylus, 5 Oct. 2012, C. Lado 22111 leg. (MAFungi 90845); Pachia, Los Olivares, route PE-40, km 43, $13 \mathrm{kms}$ west of Palca, $17^{\circ} 48^{\prime} 51.5^{\prime \prime} \mathrm{S}, 70^{\circ} 00^{\prime} 33.3^{\prime \prime} \mathrm{W}, 2345 \mathrm{~m}$ a.s.1., litter of Browningia candelaris, 5 Oct. 2012, C. Lado 22129 leg. (MA-Fungi 90868); same data as for preceeding, C. Lado 22130 leg. (MA-Fungi 90871); same data as for preceeding, C. Lado 22131 leg. (MA-Fungi 90872); same data as for preceeding, C. Lado 22135 leg. (MA-Fungi 90876).

Notes.-In South America it was only previously known from Argentina, Brazil and Chile (Lado \& al. 2011, 2013, 2014; De Lima \& Cavalcanti 2017). In Peru it was previously reported from Arequipa, Ayacucho, La Libertad and Tacna (Lado \& al. 2016). This species is one of the commonest of the territory studied and appears on all types of cacti and succulent plants.

\section{Physarum stellatum (Massee) G.W.Martin}

Specimens examined.-PERU. Cajamarca: Cajamarca, San Juan, route PE-08, km 133, Puente San Juan, 07¹6'44.2" S, 78³1'47.3" W, 1915 m a.s.l., inflorescence of Puya sp., 15 Apr. 2013, C. Lado 22599 leg. (MAFungi 90996).

Notes.-In Peru it was previously reported from the tropical forest of Madre de Dios (Rojas \& al. 2011; Rojas \& Stephenson 2013).

\section{Physarum straminipes Lister}

Specimens examined.-PERU. Ancash: Huari, Huantar, Puente Jaucan, Hueranchacra, route PE-14A, km 92, 9²5'41" S, 7709'46" W, 2687 m a.s.l., litter of Echinopsis sp., 13 May 2018, C. Lado 26563 leg. (MAFungi 91709). Cajamarca: Cajamarca, San Juan, route PE-08, km 133, Puente San Juan, $07^{\circ} 16^{\prime} 44.2^{\prime \prime}$ S, $78^{\circ} 31^{\prime} 47.3^{\prime \prime}$ W, $1915 \mathrm{~m}$ a.s.l., inflorescence of Puya sp., 15 Apr. 2013, C. Lado 22597 leg. (MA-Fungi 90994); same data as for preceeding, C. Lado 22598 leg. (MA-Fungi 90995). Lima: Yauyos, Yauyos, Auco, route PE-24, km 110, 12³6'45.3" S, $75^{\circ} 58^{\prime} 31.6^{\prime \prime} \mathrm{W}, 1775 \mathrm{~m}$ a.s.l., twigs, moist chamber culture $\mathrm{pH} 6.74$, 1 Oct. 2012, S.L. Stephenson 28940 leg. (UARK); same data as for preceeding, moist chamber culture pH 6.76, S.L. Stephenson 29158 leg. (UARK). Tacna: Pachia, Los Olivares, route PE-40, km 43, 13 kms west of Palca, $17^{\circ} 48^{\prime} 51.5^{\prime \prime} \mathrm{S}, 70^{\circ} 00^{\prime} 33.3^{\prime \prime} \mathrm{W}, 2345 \mathrm{~m}$ a.s.1., litter of Browningia candelaris, 5 Oct. 2012, C. Lado 22134 leg. (MA-Fungi 90875). Piura: Huancabamba, route PE-04E, km 49, Abra Porcuya, 5 50'28" S, 79²9'22" W, 2005 m a.s.l., twigs, 10 May 2014, C. Lado 23501 leg. (MA-Fungi 91121).

Notes.-In South America it is known from Argentina, Brazil, Chile and Peru. In Peru it was only known from Arequipa and La Libertad (Lado \& al. 2016), expanding here the distribution to Ancash, Cajamarca, Lima, Piura and Tacna.

\section{* Physarum vernum Sommerf.}

Specimens examined.-PERU. Piura: Huancabamba, route PE-04E, km 49, Abra Porcuya, $5^{\circ} 50^{\prime} 28^{\prime \prime}$ S, 79²9'22" W, 2005 m a.s.l., twigs, 10 May 2014, C. Lado 23465 leg. (MA-Fungi 91085).

Notes.-It is widely distributed throughout the Neotropics, but has not been previously reported from Peru.

\section{${ }^{\circ}$ Stemonitopsis amoena (Nann.-Bremek.) Nann.-Bremek.}

Specimens examined.-PERU. Lima: Huarochirí, Matucana, Chacahuaro, route PE-22, $\mathrm{km} 79,11^{\circ} 49^{\prime} 07.1^{\prime \prime} \mathrm{S}, 76^{\circ} 21^{\prime} 37.3^{\prime \prime} \mathrm{W}, 2515 \mathrm{~m}$ a.s.1., twigs, moist chamber culture pH 6.43, 23 Sep. 2012, S.L. Stephenson 29162 leg. 
(UARK); Huarochirí, San Mateo, route PE-22, km 80.800, 11 ${ }^{\circ} 48^{\prime 35.7 "}$ $\mathrm{S}, 76^{\circ} 21^{\prime} 01.0^{\prime \prime} \mathrm{W}, 2520 \mathrm{~m}$ a.s.1., aerial litter, moist chamber culture $\mathrm{pH}$ 6.5, 23 Sep. 2012, S.L. Stephenson 30124 leg. (UARK); same data as for preceeding, moist chamber culture $\mathrm{pH}$ 6.35, S.L. Stephenson 30125 leg. (UARK). Huancavelica: Tayacaja, route PE-3S, km 198, Izcuchaca, $7 \mathrm{~km}$ south of Izcuchaca, 12 $2^{\circ} 1^{\prime} 17^{\prime \prime} \mathrm{S}, 74^{\circ} 56^{\prime} 50^{\prime \prime} \mathrm{W}, 2840 \mathrm{~m}$ a.s.1., leaves of Puya sp., 25 Apr. 2017, C. Lado 25250 leg. (MA-Fungi 91710).

Notes.-In the Neotropics it was only reported from Costa Rica (Rojas \& al. 2010). These are the firsts records for South America. The wartedreticulate spores, the 'Comatricha-type' base of the stalk and the poorly developed or almost absent periferal capillitial net in the upper part of the sporotheca are the distinctive characters of this species (cf. NannengaBremekamp 1967, 1975).

\section{Stemonitopsis gracilis (G. Lister) Nann.-Bremek.}

Specimens examined.-PERU. Huánuco: Huánuco, Chullay, route HU111, km 11.800, 9 $57^{\prime} 40^{\prime \prime}$ S, 76 $25^{\circ} 40^{\prime \prime}$ W, 2630 m a.s.l., leaves of Agave americana, 17 May 2018, C. Lado 26934 leg. (MA-Fungi 91711).

Notes.-In South America it was only reported from Argentina, Brazil and Ecuador (Lado \& al. 2011, 2017; De Lima \& Cavalcanti 2017). In Peru, one collection from Cajamarca was recorded by Lado \& al. (2016).

\section{* Stemonitopsis subcaespitosa (Peck) Nann.-Bremek.}

Specimens examined.-PERU. Lima: Yauyos, Yauyos, route PE-24, km 124, 12 $31^{\prime} 56.7^{\prime \prime}$ S, 7554'52.6" W, 2180 m a.s.1., litter of Haageocereus decumbens, 1 Oct. 2012, C. Lado 22010 leg. (MA-Fungi 90830). Ancash: Huari, 21 km from Huari towards San Marcos, 9²8'02" S, 7708'37" W, 2827 m a.s.1., branch of Baccharis latifolia, 21 May 2014, C. Lado 23722 leg. (MA-Fungi 91152).

Notes.-It is widely distributed throughout the Neotropics, but has not been previously reported from Peru.

Trichia agaves (G.Moreno, Lizárraga \& Illana) Mosquera, Lado, Estrada \& Beltrán-Tej. Fig. 7i-1.

Specimens examined.-PERU. Ancash: Huaraz, Pariacoto, route PE-14, km 79, 09³2'16.1" S, 7746'07.4" W, 2569 m a.s.1., leaves of Agave americana, 17 Apr. 2013, C. Lado 22665 leg. (MA-Fungi 91004); same data as for preceeding, C. Lado 22670 leg. (MA-Fungi 91010); same data as for preceeding, C. Lado 22671 leg. (MA-Fungi 91012); same data as for preceeding, C. Lado 22673 leg. (MA-Fungi 91014); same data as for preceeding, C. Lado 22677 leg. (MA-Fungi 91019); same data as for preceeding, C. Lado 22678 leg. (MA-Fungi 91020); same data as for preceeding, C. Lado 22679 leg. (MA-Fungi 91021); Huaylas, Caraz,

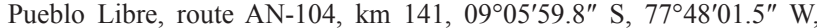
$2466 \mathrm{~m}$ a.s.1., leaf bases of Furcraea occidentalis, moist chamber culture pH 7.89, 20 Apr. 2013, D. Wrigley de Basanta 3685 leg. (dwb); same data as for preceeding, leaves of Agave americana, C. Lado $22932 \mathrm{leg}$. (MA-Fungi 91035); same data as for preceeding, C. Lado 22935 leg. (MA-Fungi 91038); same data as for preceeding, C. Lado $22936 \mathrm{leg}$. (MA-Fungi 91039); same data as for preceeding, C. Lado $22937 \mathrm{leg}$. (MA-Fungi 91040); same data as for preceeding, leaves of Furcraea occidentalis, C. Lado 22948 leg. (MA-Fungi 91051); same data as for preceeding, C. Lado 22949 leg. (MA-Fungi 91052). Apurimac: Abancay,

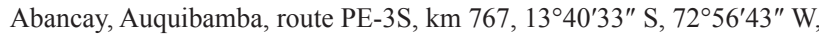
2158 m a.s.1., leaves of Agave americana, 19 Apr. 2016, C. Lado 24545 leg. (MA-Fungi 91712); same data as for preceeding, C. Lado 24552 leg. (MA-Fungi 91713). Cajamarca: Cajamarca, San Juan, route PE-08, km 133, Puente San Juan, 07¹6'44.2" S, 78³1'47.3" W, 1915 m a.s.l., leaves of Puya sp., 15 Apr. 2013, C. Lado 22602 leg. (MA-Fungi 90999). Huancavelica: Tayacaja, route PE-3S, km 193, Izcuchaca, $2 \mathrm{~km}$ south of Izcuchaca, 12 $2^{\circ} 30^{\prime} 23^{\prime \prime}$ S, 74 58'40" W, 2856 m a.s.1., leaves of Agave americana, 25 Apr. 2017, C. Lado 25258 leg. (MA-Fungi 91714); same data as for preceeding, C. Lado 25261 leg. (MA-Fungi 91667); same data as for preceeding, C. Lado 25262 leg. (MA-Fungi 91668). Huánuco: Huánuco, Chullay, route HU-111, km 11.800, 957'40" S, 76²5'40" W, 2630 m a.s.1., leaves of Agave americana, 17 May 2018, C. Lado 26935 leg. (MA-Fungi 91715). Lima: Huarochirí, Matucana, Chacahuaro, route

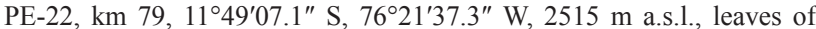
Agave americana, 23 Sep. 2012, C. Lado 21712 leg. (MA-Fungi 90772); same data as for preceeding, C. Lado 21713 leg. (MA-Fungi 90773); same data as for preceeding, C. Lado 21714 leg. (MA-Fungi 90774); same data as for preceeding, C. Lado 21716 leg. (MA-Fungi 90777); same data as for preceeding, C. Lado 21720 leg. (MA-Fungi 90781); same data as for preceeding, C. Lado 21730 leg. (MA-Fungi 90794); same data as for preceeding, C. Lado 21732 leg. (MA-Fungi 90796); Canta, $6 \mathrm{~km}$ south

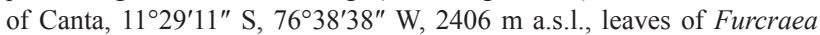
andina, 18 May 2014, C. Lado 23641 leg. (MA-Fungi 91143).

Notes.-In South America it was only known from Argentina (Lado \& al. 2011), Brazil (Cavalcanti 2010) and Peru (Lado \& al. 2016); in Peru it was reported from Cajamarca. This species, common on leaves of succulent plants, like species of Agave, Furcraea and Puya, has tenous spirals ornamented with few and short blunt spines in the capillitium (fig. 7i), and warted spores (fig. $7 \mathrm{j}-1$ ).

\section{* Trichia contorta var. iowensis (T.Macbr.) Torrend}

Specimens examined.-PERU. Ancash: Huaraz, Pariacoto, route PE-14, km 79, 09³2'16.1" S, 7746'07.4" W, 2569 m a.s.l., cladode of Opuntia ficus-indica, 17 Apr. 2013, C. Lado 22680 leg. (MA-Fungi 91022).

Notes.-In South America, this variety was previously reported only from Argentina (Lado \& al. 2014).

\section{* Trichia scabra Rostaf.}

Specimens examined.-PERU. Huancavelica: Tayacaja, route PE-3S, $\mathrm{km}$ 198, Izcuchaca, $7 \mathrm{~km}$ south of Izcuchaca, 12 $31^{\prime} 17^{\prime \prime} \mathrm{S}, 74^{\circ} 56^{\prime} 50^{\prime \prime} \mathrm{W}$, 2840 m a.s.1., leaves of Puya sp., 25 Apr. 2017, C. Lado 25249 leg. (MAFungi 91716).

Notes.-It is widely distributed throughout the Neotropics, but was not reported previously from Peru.

\section{Willkommlangea reticulata (Alb. \& Schwein.) Kuntze}

Specimens examined.-PERU. Huancavelica: Angaraes, route PE-26B, $\mathrm{km} \mathrm{158,} 4 \mathrm{~km}$ west of Laramate, $13^{\circ} 01^{\prime} 48^{\prime \prime}$ S, $74^{\circ} 23^{\prime} 48^{\prime \prime}$ W, $2890 \mathrm{~m}$ a.s.1., wood of Acacia sp., 22 Apr. 2017, C. Lado 25043 leg. (MA-Fungi 91717).

Notes.-In Peru it was previously reported from Loreto and Piura (Wrigley de Basanta \& al. 2008a; Lado \& al. 2016).

\section{DISCUSSION}

The results of the survey of these habitats yielded 601 collections of myxomycetes representing 84 species in 19 genera and in all the five orders recognised in this group. These collections include one species that is new to science. This biogeographical area was virtually unexplored for myxomycetes and the results have added 26 species to the myxobiota reported from Peru. This increases the number of myxomycetes recorded in the country so far to 153 species, and extends the known distribution of many species.

In order to more effectively compare these results with the first set of data from the dry coastal areas and lomas formations (Lado \& al. 2016), the arid belt below the 
area under study here, we have used the same structure of analysis as that paper. The predominant order in this survey was the Physarales T.Macbr. with 50 species, almost a $60 \%$ of the recovered taxa. This order was followed by the Trichiales T.Macbr. and the Stemonitidales T.Macbr. (fig. 8). The orders with the lowest number of species were the Cribrariales T.Macbr. and Echinosteliales G.W.Martin. The predominance of the order Physarales is even more obvious when the total number of collections is taken into account, where more than $60 \%$ of the total belonged to this order, almost $30 \%$ to the Trichiales and only $8.2 \%$ to the remaining three orders. When compared with the results from the coastal desert of Peru (Lado \& al. 2016), the distribution of the orders and also the total numbers of species are similar (fig. 8), and show no statistical difference $\left(\chi^{2} 0.11\right.$, df $\left.3, \mathrm{P} 0.9906\right)$. There are approximately ten species from the Physarales for every seven species from the remaining orders. However at the species level there are some significant differences. The most commonly collected species were Badhamia melanospora (77 collections), Trichia agaves (29), Physarum spectabile (27), Perichaena vermicularis (24), Didymium vaccinum (22), Perichaena quadrata (22), Perichaena depressa (22), Didymium nigrisporum (20) and Physarum clavisporum (20). The three first species can be considered to be particulary abundant $(>4 \%$ relative abundance) and the most representative of this Peruvian habitat, since they make up $21.8 \%$ of all collections. On the other hand, $30 \%$ of the studied species were represented by only a single collection, an indicative percentage of a diverse assemblage.

In the coastal desert and lomas formations (Lado \& al. 2016) the most commonly collected species was also Badhamia melanospora (139 collections), followed by Physarum atacamense (135), Didymium nigrisporum (65), Physarum pusillum (47), Physarum clavisporum (35), Perichaena vermicularis (33), Arcyria insignis (26) and
Physarum compressum (21). The only species commonly appearing in both studies were Badhamia melanospora, Perichaena vermicularis and Physarum clavisporum. This indicates a high level of diversity in both the areas since, in spite of the fact that they are neighbouring territories, many species appear to be replaced by others in the same genus. From the total of 84 species reported for the 'cardonal', $42 \%$ are common to this area and the coastal desert, but $32 \%$ appeared only in the 'cardonal' area, and $26 \%$ were only collected in the coastal desert.

The mean number of species per genus $(\mathrm{S} / \mathrm{G})$, a measure of taxonomic diversity used in other studies of myxomycetes (Stephenson \& al. 1993), shows overall higher diversity the lower the value. $\mathrm{S} / \mathrm{G}$ ratio in the 'cardonal' was 4.42, whereas that of the coastal lomas showed more diversity since the ratio was 3.5 . This is possibly due to the presence of a greater variety of plant substrates on the coast, where endemic and coastal plants, such as Tillandsia purpurea Ruiz \& Pav. or Capparis scabrida Kunth, are frequent as well as many seasonal herbaceous plants. These provided microhabitats for more different genera of myxomycetes and so increased the diversity. In the 'cardonal' there were columnar cacti such as Armatocereus matucanensis Backeb. ex A.W.Hill, Corryocactus brevistylus (K.Schum. ex Vaupel) Britton \& Rose, Weberbauerocereus weberbaueri (K.Schum. ex Vaupel) Backeb., as well as succulent plants such as Agave americana L., Furcraea andina Trel. and perennial shrubs like Baccharis latifolia (Ruiz \& Pav.) Pers., providing possibly more stable moist conditions but for fewer genera.

Of the 84 species identified from this survey, 51 were only collected in the field and seven were only obtained from moist chamber culture, while 26 were recovered from both. In the field collections, $71 \%$ of the specimens found were represented by 20 species, whereas in moist chamber cultures this percentage was made up of 14 species. Six additional species, abundant in field collections, were
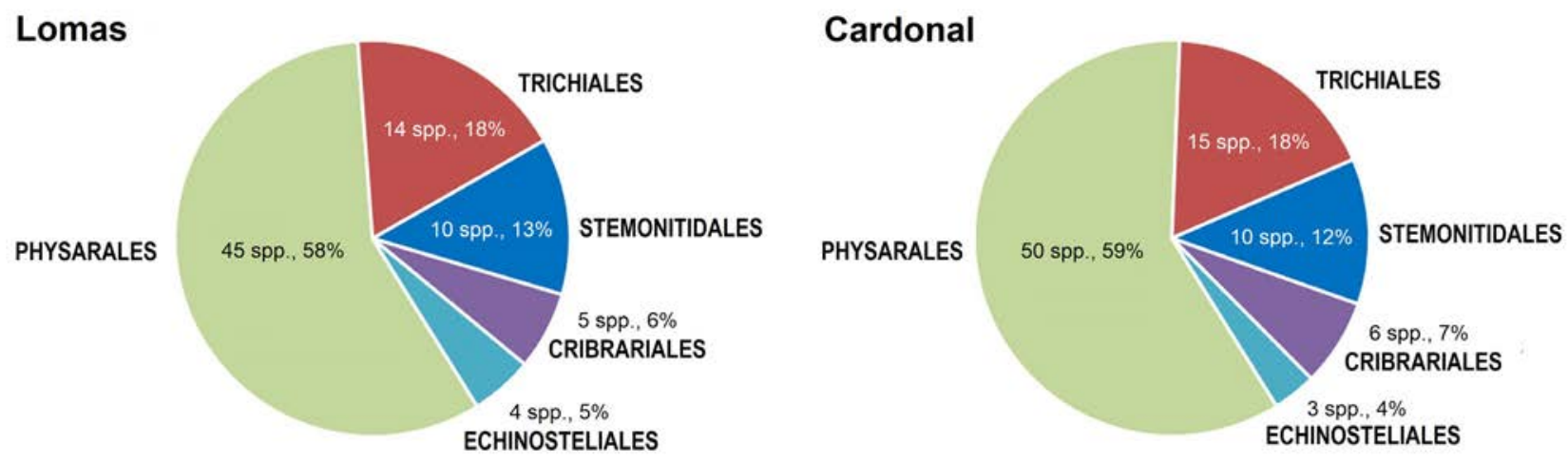

Fig. 8. Comparison of results by orders between arid areas of Peru: lomas (Lado \& al. 2016) and cardonal. 
Table 1. Comparison of sampling methods by number of collections and number of species in each survey (some of the same species were collected using both methods).

\begin{tabular}{lcccccc} 
& \multicolumn{2}{c}{ Physarales } & \multicolumn{2}{c}{ Trichiales } & \multicolumn{2}{c}{ Other orders } \\
\cline { 2 - 7 } & Lomas & Cardonal & Lomas & Cardonal & Lomas & Cardonal \\
\hline Field & & & & & & \\
$\quad$ collections & 424 & 323 & 65 & 142 & 11 & 21 \\
$\quad$ species & 36 & 47 & 11 & 15 & 11 & 15 \\
\hline Moist chamber & 142 & 51 & 37 & 36 & 42 & 28 \\
$\quad$ collections & 23 & 14 & 10 & 10 & 12 & 9 \\
\hline species & & & & & & \\
\hline
\end{tabular}

Table 2. Number of collections in each order from each vegetation type.

\begin{tabular}{|c|c|c|c|c|c|}
\hline & Physarales & Trichiales & Stemonitidales & Echinosteliales & Cribrariales \\
\hline Cardonal & 374 & 178 & 25 & 11 & 13 \\
\hline $1500-3000 \mathrm{~m}$ a.s.1. & $z=-2.61$ & $z=+4.50$ & $z=-0.18$ & $z=-0.11$ & $z=+1.49$ \\
\hline $\begin{array}{c}\text { Lomas } \\
\text { C }\end{array}$ & $\begin{array}{c}566 \\
=+238\end{array}$ & 102 & $\begin{array}{l}32 \\
=+016\end{array}$ & $\begin{array}{l}14 \\
=+010\end{array}$ & $\begin{array}{c}6 \\
-136\end{array}$ \\
\hline
\end{tabular}

rarely collected in the moist chamber cultures or not at all. Both techniques showed that Badhamia melanospora is the most dominant species. The results show that the technique of moist chamber culture in conjunction with field collecting are complementary methods and more likely to reflect the actual myxomycetes present in the area. In such arid extreme environments where field collecting may not reveal all the myxobiota, especially the more minute species, the dual methodology is essential, as has been stated previously (Lado \& al. 2016). For instance, the order Physarales had fewer than expected collections from moist chamber cultures $(z-2.39, \mathrm{P} 0.0084)$, and more than expected collections of other orders (Stemonitidales, Echinosteliales and Cribrariales, $z$ 6.39, $\mathrm{P}<0.0001)$. The latter groups had fewer field collections than expected, $(z-4.25, \mathrm{P}<0.0001)$, probably because the smaller species in those orders, such as Echinostelium arboreum or Echinostelium colliculosum are very difficult to detect in the field. The benefits of the dual methodology are reinforced once more by the tests of independence done on the proportion of collections and species (table 1) recovered from the field or from moist chamber culture in each survey. For the proportion of collections from different orders $\chi^{2}=53.19$ (df 2; $\mathrm{P}<0.0001$ ), indicating that the number of collections of different groups of myxomycetes depends on whether they were collected in the field or from moist chamber culture. For the proportion of species from different orders, however, $\chi^{2}=3.28$ (df 2 ; P 0.194), which reiterates the fact that the distribution of orders is independent of the method used to collect the specimens (field or culture).

When the number of collections from each order in each of the surveys is compared the statistical analysis shows that the vegetaion type studied does affect the relative abundance of myxomycetes in each order $\left(\chi^{2} 53.76\right.$, df $4, \mathrm{P}<0.0001)$. The standardized residuals indicate no significant difference from the expected frequency for orders Stemonitidales, Echinosteliales and Cribrariales $(\mathrm{P}>0.05)$. However the Physarales in the 'cardonal' show a lower than expected frequency $(z-2.61, \mathrm{P} 0.0045)$ and higher than expected in the coastal desert (table 2). The opposite occurs for the Trichiales, where the frequency in the 'cardonal' is higher than expected and lower than expected in the coastal desert. This indicates how the differences in vegetation shape the myxomycete communities within them, with decaying cacti and succulent plants favoring the development of species of the Trichiales.

The remains of cacti from 13 genera and 21 species were examined or cultured and the most productive of them were species of genera Haageocereus and Opuntia, although overall they were only the third most productive substrates with 34 collections each. However the remains of all species of cacti taken together produced 26 species of myxomycetes in 161 collections, and these made up $26.8 \%$ of the results. This is slightly more than the $23 \%$ of collections representing only 15 species recovered from all the cacti present in the coastal desert (Lado \& al. 2016). The dead leaves and other remains of the bromeliad genus Puya were the most productive substrate, with 89 collections from 40 different myxomycete species and so more diverse as substrates than cacti. The species of this plant genus are distributed exclusively in the Neotropics, and in Peru they are a characteristic element of the western slopes of the Andes, growing mostly on steep-sloped rocky terrain (fig. $1 \mathrm{i}-\mathrm{m}$ ). The arrangement, in the form of a rosette, of the leaves of these plants, channels the water, 
from the scarce precipitation, towards the stem, where it progressively moistens the dead leaves that still remain attached and whose decomposition is very slow, given their coriaceous nature. This arrangement guarantees increased humidity since it prevents rapid desiccation, creating a microhabitat that is used by myxomycetes for their development. The populations of Agave, that in Peru, are usually associated with agricultural lands, produced 81 collections of myxomycetes $(13.5 \%)$ in this survey with 17 species. In the coastal desert, the most productive and diverse genera of plants were Capparis L. and Tillandsia L.

The most productive locality was Plazapalapa in the administrative department of La Libertad at $7^{\circ} 59^{\prime} \mathrm{S}$ latitude and an elevation of $1742 \mathrm{~m}$ a.s.l. which produced the most collections (72) and the greatest number of species (25). The productivity of this locality may be due to the greater density of vegetation associated with its more protected position in the valley and its proximity to a watercourse, that provides more moisture and, therefore, more vegetation and plant remains in decomposition for the development of myxomycetes. More than half of the collections were produced by only seven sampled localities (304 collections), located between $5^{\circ}$ and $13^{\circ} \mathrm{S}$, whereas in the coastal survey 14 localities produced a half of the collections (375). Nevertheless, some of the localities showed very unequal values over the six years of study. This may be due to the environmental conditions of each year, as well as to the physical geography of the territory and the role that the microhabitat has in the appearance of myxomycetes. The localities with 'cardonal' from the north of Peru, between the latitudes $5^{\circ}$ and $11^{\circ} \mathrm{S}$, had a greater number of collections (372) than the south (229), located between the latitudes $12^{\circ}$ and $18^{\circ} \mathrm{S}$. This may be due to proximity to the moisture of the tropical areas and the subsequent increased variety in vegetation, whereas the aridity is higher in the southern Peru due to the proximity to the Atacama Desert and the greater influence of the Humbolt stream. The elevation range where the greatest number of collections was made (196) was 2400-2700 m a.s.l., followed by $1500-1800 \mathrm{~m}$ a.s.l. (166), but the number of collections taking into account the number of collecting localities, was highest at the elevations between 1500-1800 m a.s.l. (33.2 collections per locality) and 2400-2700 m a.s.l. (16.33).

The comparison of the $\mathrm{pH}$ of the substrates reveals that the moist chamber cultures in this survey had a similar range to those of the coast (fig. 9) and the majority of myxomycetes collected from them were from substrates around $\mathrm{pH} 6$ or 7 . However there were more species collected from substrates in the acid range in the coastal deserts ( $\mathrm{pH} \mathrm{5-7)} \mathrm{and} \mathrm{more} \mathrm{in} \mathrm{the} \mathrm{slightly} \mathrm{basic} \mathrm{range} \mathrm{in} \mathrm{the}$ 'cardonal' ( $\mathrm{pH}$ 6-8). As it has been pointed out (Wrigley de Basanta 2004), some myxomycetes are very $\mathrm{pH}$ sensitive and some have $\mathrm{pH}$ optima, and the internal tissues of cacti, like those in the 'cardonal', have a basic $\mathrm{pH}$ at certain times in their process of decay (Mosquera \& al. 2003; EstradaTorres \& al. 2009).

According to the estimators CHAO1 and ACE, the expected species richness if the sampling effort had been exhaustive would be 115 and 107 respectively (fig. 10), therefore, the 84 registered species represent $73 \%$ and $79 \%$ of the estimate. Based on the Clench function, the estimated number of species, with an $\mathrm{r}^{2} 0.999$, was 122 , indicating a good fit of the data to the curve (fig. 11), and giving a value slightly higher than that estimated using CHAO 1. According to the Clench function, this survey registered almost $70 \%$ of all possible species in the sampling area, and very similar to that of the coastal desert survey (63-69\%). Considering the extremely arid conditions of the 'cardonal' area, this is a most satisfactory result. The extrapolation of the species richness, using the program EstimateS, showed that if 18 more collecting localities had been visited, under the same collecting conditions as those used in the survey, this would have returned only 15 species more.

Using the above estimators, the field collections alone, by both CHAO1 and ACE, showed that $79 \%$ and $75 \%$, respectively, of the species theoretically possible were recorded. Using moist chamber cultures alone, both CHAO1 and ACE showed that $79 \%$ and $83 \%$ of possible species were recovered, a slightly more efficient result probably on account of the more stable favourable conditions that existed in the culture. This productivity is similar to that of the coastal area (Lado \& al. 2016), but in the 'cardonal' $97 \%$ of the localities visited yielded identifiable myxomycetes.

To examine the similarities between the area studied and other dryland surveys in the Americas, done by the same team and using the same methods, the percentage complementarity was calculated for each (table 3 ).

The assemblages of myxomycetes in the different areas compared in table 3 showed fairly low similarity between the species recovered, with less than $50 \%$ of the same species collected in any two studies. From a total of 191 species reported, only 17 species $(8.9 \%)$ of these were recovered in all of the areas compared here, and 104 species $(54.45 \%)$ appeared in only one.

Unsurprisingly the highest number of species shared in common with those found in the 'cardonal' belt of the Peruvian Andes was for the study of the neighbouring arid coastal area of lomas in Peru, with the species assemblage of these areas the most similar of those in table 3 . This was followed by the Monte desert in Argentina and Tehucán in Mexico, and the least similar to this area of Peru of those studied was Chile. Several factors may help to explain the results. The relative proximity of the study sites in the two 
60

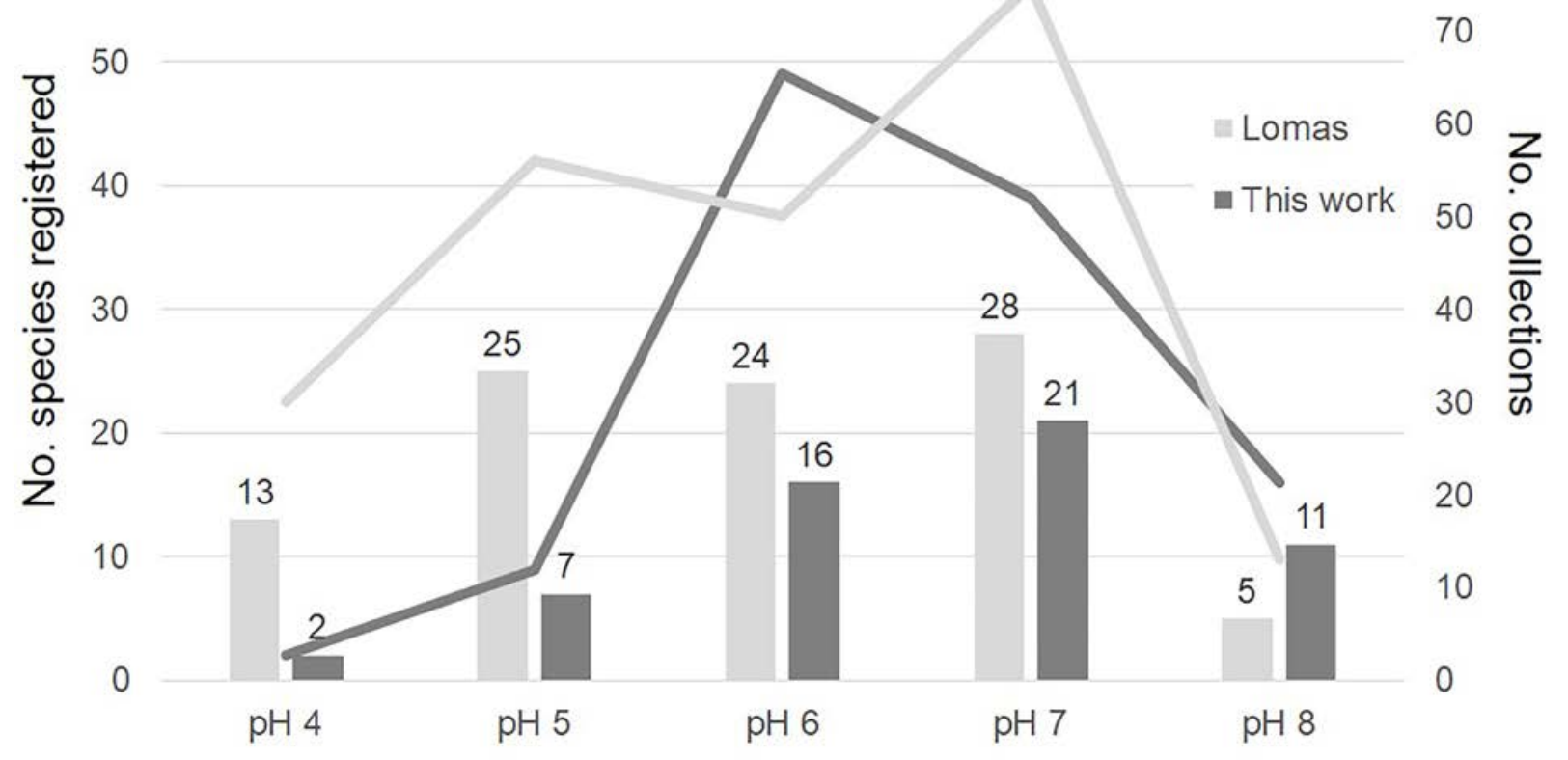

Fig. 9. Number of collections (lines) and species (bars) of Myxomycetes recorded, at each different substrate pH in moist chamber cultures from this survey and from lomas in the coastal desert (Lado \& al. 2016).

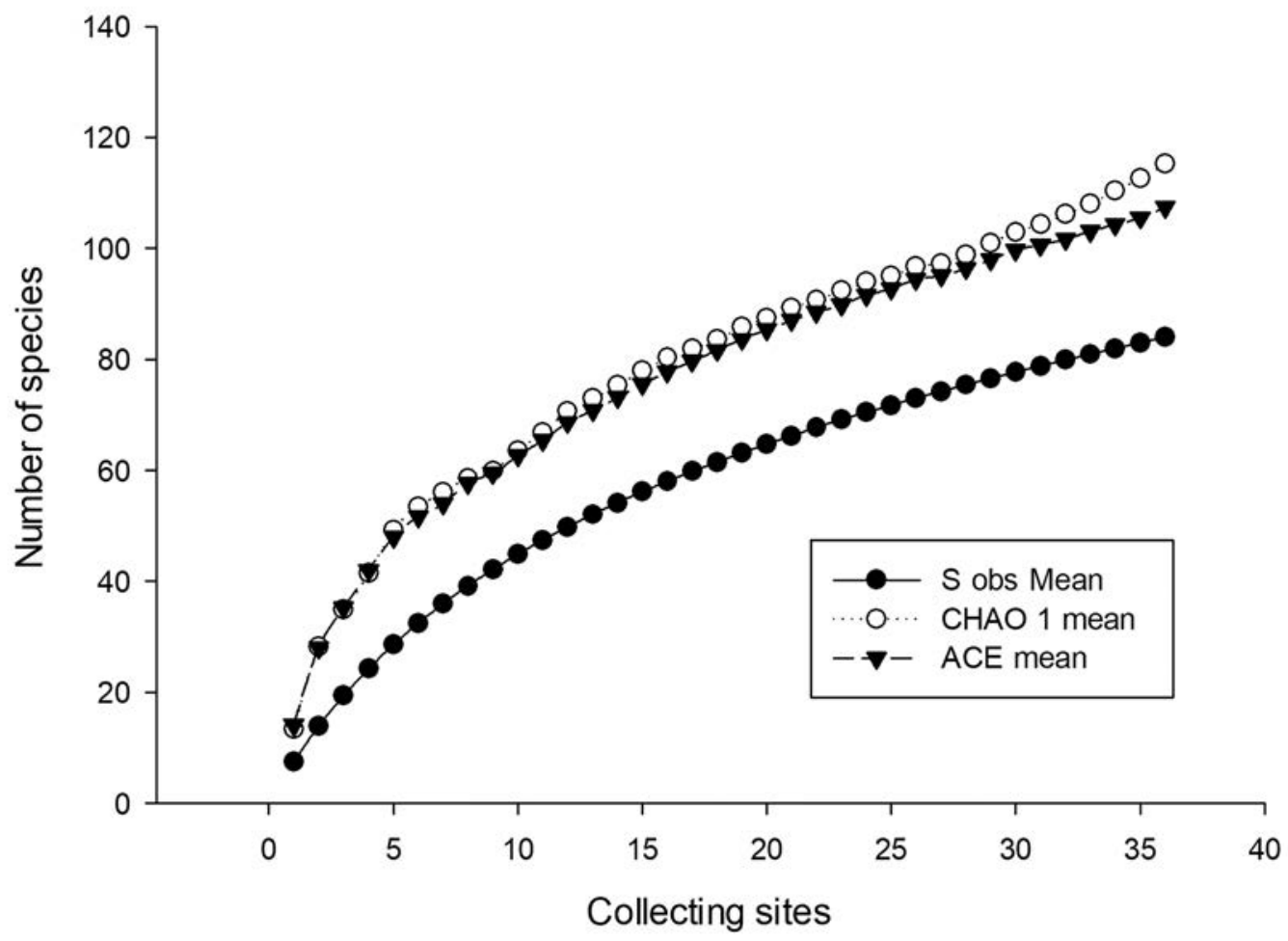

Fig. 10. Species accumulation curves using ACE and CHAO1. 
Table 3. Percentage complementarity of the assemblage of myxomycetes with some other arid areas in the Neotropics. Note: CC bottom left, number of species in common top right. References: ${ }^{1}$ this article; ${ }^{2}$ Lado \& al. (2016); ${ }^{3}$ Lado \& al. (2011); ${ }^{4}$ Estrada-Torres \& al. (2009); ${ }^{5}$ Lado \& al. $(2007,2013)$ and Wrigley de Basanta \& al. $(2011,2012)$.

\begin{tabular}{|c|c|c|c|c|c|}
\hline & Peru Cardonal $^{1}$ & Peru Lomas ${ }^{2}$ & Argentina Monte $^{3}$ & Mexico Tehuacán ${ }^{4}$ & Chile Regions I-IV 5 \\
\hline Peru Cardonal $^{1}$ & $* * *$ & 48 & 39 & 46 & 31 \\
\hline Peru Lomas ${ }^{2}$ & 0.5752 & $* * *$ & 35 & 44 & 26 \\
\hline Argentina Monte ${ }^{3}$ & 0.6667 & 0.6930 & $* * *$ & 42 & 29 \\
\hline Mexico Tehuacán ${ }^{4}$ & 0.6761 & 0.6788 & 0.6866 & $* * *$ & 17 \\
\hline Chile Regions I-IV 5 & 0.6900 & 0.7347 & 0.6778 & 0.8731 & $* * *$ \\
\hline Range of elevation (m a.s.1.) & $1500-3000$ & $0-1500$ & $500-4500$ & $600-2950$ & $0-4800$ \\
\hline Annual temperature range $\left({ }^{\circ} \mathrm{C}\right)$ & $11-24$ & $12-17$ & $10-18$ & $16-30$ & $12-25$ \\
\hline Annual rainfall (mm) & $225-450$ & $125-250$ & $50-450$ & $300-1000$ & $0-78$ \\
\hline
\end{tabular}

Peruvian surveys results in an exchange and interchange of species, but differences such as the low elevation and coastal fogs of the lomas allow totally different plant substrates to grow, such as plants from the very productive genera Capparis and Tillandsia, and no columnar cacti. The Monte desert in Argentina is on the other side of the geographical barrier of the Andes mountains, but there are some corridors for exchange of species from one side to the other. However the elevation gradient was of a wider range (500-4500 m a.s.1.) in the Argentinian drylands study and the rain shadow has possibly a greater effect on the eastern slopes, and the plant species are different so there was a broader range of plant genera as substrates to account for the differences. On the other hand, the Tehuacán-Cuicatlán valley in Mexico had a similar range of elevation and has large columnar and candelabra cacti such as species of Cephalocereus, Neobuxbaumia, Stenocereus, Pachycereus, Pilosocereus and Myrtillocactus, which dominate over extensive areas (Estrada-Torres \& al. 2009), affecting the number of common myxomycete species (46) with the present survey. However Tehuacán is in the northern hemisphere and therefore the distance for species exchange is greater. The most different assemblage was in the very dry areas of Chilean Regions I-IV which, being further

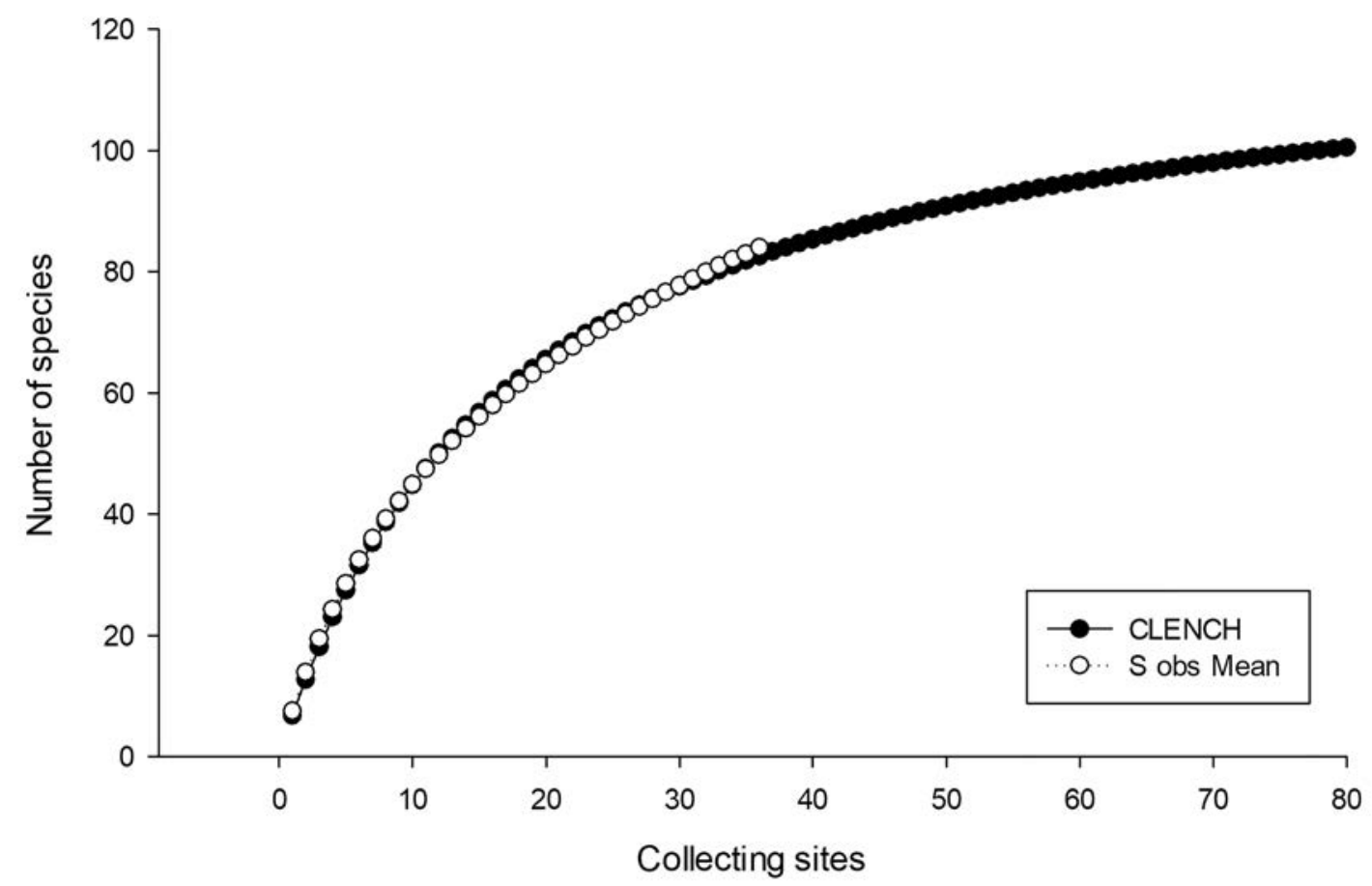

Fig. 11. Species accumulation curve using the adjustment by Clench. 
from the equator than the Peruvian deserts, are even more arid. The methodology may also have affected the results, since the Chilean surveys were from $0-4800 \mathrm{~m}$ a.s.1. and so, covered the range of both Peruvian studies.

In terms of species some, such as Badhamia melanospora, Didymium wildpretii, Licea succulenticola or Physarum spectabile seem to appear more readily in arid areas than others suggesting an assemblage specific to these xerophyllous conditions or to the plants that inhabit these environments. This indicates that some species are associated with specific environments or specific plants in those environments and reinforces the idea that each area has its own characteristic myxobiota as suggested previously (Wrigley de Basanta \& al. 2010a, 2013; Lado \& al. 2016). The influence of microhabitat conditions on these microorganisms and the indirect effect of macrohabitat factors have been pointed out in many studies before (Estrada-Torres \& al. 2009; Wrigley de Basanta \& al. 2010a, 2013; Lado \& al. 2016) and is confirmed by these results. In particular, the analysis of the results from the two surveys of extreme xerophyllous overlapping environments in Peru, using similar methods, has revealed that each vegetational belt has some similarity in the myxomycete assemblage of species. However more surprisingly there are striking differences, especially at the species level, between the two types of vegetation with an exchange of species of more than $57 \%$, as shown above. The differences appear to be more related to the biotic factors of each area than to abiotic factors. The climatic, orographic and edaphic factors influence the availability of host plants but it is these in turn that influence the myxomycete assemblage of the area.

\section{ACKNOWLEDGEMENTS}

This research was supported by the Spanish Government grants CGL2011-22684 and CGL2014-52584P. We are grateful to Asuncion Cano, Museo de Historia Natural, Lima, Peru, and Universidad Nacional Mayor de San Marcos, Lima, Peru, for his assistance with collecting permits, and other aspects of the project, and to Gloria Rebaza, Joaquina García, Jenny Rojas-Fox, Johanny Molina and Susi Castillo for their help with fieldwork. We also thank Yolanda Ruiz for her technical assistance with SEM, Carlos de Mier for his help with the images and micrographs, and Juan Carlos Hernández for database management. Italo Treviño is gratefull to PRONABEC (Beca Presidente de la República-2017-II) for the research grant. Peruvian field work and collections were authorised by collecting and/or exportation permit no. 292-2012-AG-DGFFS-DGEFFS and no. 118-2016-SERFOR-DGGSPFFS from the Dirección General de Gestión Sostenible del Patrimonio Forestal y de Fauna Silvestre y la Dirección General del Servicio Forestal, Peru.

\section{REFERENCES}

Araújo J.C., Lado C. \& Xavier-Santos S. 2015. Perichaena calongei (Trichiales): a new record of Myxomycetes from Brazil. Current Research in Environmental \& Applied Mycology 5 (4): 357-361. https://doi.org/10.5943/cream/5/4/5

Cavalcanti L.H. 2002. Biodiversidade e distribuição de mixomicetos em ambientes naturais e antropogênicos no Brasil: espécies ocorrentes nas Regiões Norte e Nordeste. In Araújo E.L. \& al. (eds.), Biodiversidade, Conservaçao e Uso Sustentável da Flora do Brasil: 209-216. UFPE, Sociedade Botânica do Brasil, Recife. https://doi.org/10.11606/t.85.2018.tde-15082018-145627

Cavalcanti L.H. 2010. Stemonitales. In Forzza \& al. (eds.), Catálogo de plantas e fungos do Brasil 1: 100-102. Andrea Jakobsson Estúdio, Rio de Janeiro.

Cavalcanti L.H., Bezerra A.C.C., Barbosa D.I., Agra L.A.N.N., Powell N.V., De Lima V.X. \& Costa A.A.A. 2016. Occurrence and distribution of Perichaena (Trichiaceae, Myxomycetes) in the Brazilian Northeastern Region. Acta Botanica Brasilica 30 (1): 102-111. https://doi.org/10.1590/0102-33062015abb0238

Clark J. \& Landol J.C. 2001. Myxomycete biosystematics: various Didymium and Physarum species. Nova Hedwigia 73 (3-4): 437-444.

Colwell R.K. 2013. EstimateS, version 9.1.0: Statistical Estimation of Species Richness and Shared Species from Samples. Website: http://viceroy.eeb.uconn.edu/estimates/ [accessed: 11 Nov. 2018].

Colwell R.K. \& Coddington J.A. 1994. Estimating terrestrial biodiversity through extrapolation. Philosophical Transactions of the Royal Society, Series B 345: 101-118. https://doi.org/10.1098/rstb.1994.0091

Colwell R.K., Mao C.X. \& Chang J. 2004. Interpolating, extrapolating, and comparing incidence-based species accumulation curves. Ecology 85: 2717-2727. https://doi.org/10.1890/03-0557

De Lima V.X. \& Cavalcanti L.H. 2017. Diversity and ecology of Myxomycetes in the Pampa Biome, Brazil. Nova Hedwigia 104 (1-3): 273-291. https://doi.org/10.1127/nova hedwigia/2016/0360

Eliasson U.H. \& Nannenga-Bremekamp N.E. 1983. Myxomycetes of the Scalesia forest, Galápagos Islands. Proceedings Konienklijke Nederlandse Akademie van Wetenschappen Series C 86 (2): 143-153.

Estrada-Torres A., Lado C. \& Rodríguez-Palma M. 2001. Two new species of Myxomycetes from a tropical deciduous forest of Mexico. Mycologia 93 (4): 744-750. https://doi.org/10.2307/3761829

Estrada-Torres A., Wrigley de Basanta D., Conde E. \& Lado C. 2009. Myxomycetes associated with dryland ecosystems of the TehuacánCuicatlán Valley Biosphere Reserve, Mexico. Fungal Diversity 36: 1756. https://doi.org/10.1007/s13225-013-0236-7

Farr M.L. 1976. Myxomycetes. In Rogerson C.T. (ed.), Flora Neotropica 16: 1-305. New York Botanical Garden, New York.

Guo M.Q. \& Chen S.L. 2014. Cribraria microcarpa var. megaspora, one new variety of myxomycetes from China. Mycosystema 33 (1): 15-18.

Härkönen M. 1977. Comatricha nannengae, a new species of Myxomycetes. Karstenia 17: 87-89. https://doi.org/10.29203/ ka.1977.128

Härkönen M. 1978. Comatricha ellae, nomen novum (Myxomycetes). Karstenia 18: 23. https://doi.org/10.29203/ka.1978.131

Illana C., Moreno G. \& Lizárraga M. 2000. Catálogo de Myxomycetes de México. Stapfia 73: 167-186.

Jiménez-Valverde J. \& Hortal J. 2003. Las curvas de acumulación de especies y la necesidad de evaluar la calidad de los inventarios biológicos. Revista Ibérica de Aracnología 8: 151-161.

Keller H.W. \& Eliasson U.H. 1992. Taxonomic evaluation of Perichaena depressa and P. quadrata based on controlled cultivation, with additional observations on the genus. Mycological Research 96 (12): 1085-1097. https://doi.org/10.1016/s0953-7562(09)80120-2

Kelly K.L. \& Judd D.B. 1976. ISCC-NBS Color Name Charts Illustrated with Centroid Colors. Inter-Society Color Council. National Bureau of Standards, Washington. 
Kirk P.M., Cannon P.F., Minter D.W. \& Stalpers J.A. 2011. Dictionary of the Fungi. CABI International, Oxon.

Lado C. 2005-2018. Nomen.eumycetozoa.com. An online nomenclatural information system of Eumycetozoa. Website: http://www.nomen.eumycetozoa.com [accessed: 10 Oct. 2018].

Lado C. \& Wrigley de Basanta D. 2008. A review of Neotropical Myxomycetes (1828-2008). Anales del Jardín Botánico de Madrid 65 (2): 211-254. https://doi.org/10.3989/ajbm.2008.v65.i2.293

Lado C., Mosquera J. \& Beltrán-Tejera E. 1999. Cribraria zonatispora, development of a new myxomycete with unique spores. Mycologia 91 (1): 157-165. https://doi.org/10.2307/3761205

Lado C., Estrada-Torres A. \& Stephenson S.L. 2007a. Myxomycetes collected in the first phase of a north-south transect of Chile. Fungal Diversity 25: 81-101.

Lado C., Mosquera J., Estrada-Torres A. \& Wrigley de Basanata D. 2007b. Description and culture of a new succulenticolous Didymium (Myxomycetes). Mycologia $99 \quad$ (4): 602-611. https://doi.org/10.1080/15572536.2007.11832554

Lado C., Wrigley de Basanta D., Estrada-Torres A., García Carvajal E., Aguilar M. \& Hernández J.C. 2009. Description of a new species of Perichaena (Myxomycetes) from arid areas of Argentina. Anales del Jardín Botánico de Madrid 66 (S1): 63-70. https://doi.org/10.3989/ajbm.2229

Lado C., Wrigley de Basanta D. \& Estrada-Torres A. 2011. Biodiversity of Myxomycetes from the Monte Desert of Argentina. Anales del Jardin Botánico de Madrid 68 (1): 61-95. https://doi.org/10.3989/ajbm.2266

Lado C., Wrigley de Basanta D., Estrada-Torres A. \& Stephenson S.L. 2013. The biodiversity of myxomycetes in central Chile. Fungal Diversity 59: 3-32. https://doi.org/10.1007/s13225-012-0159-8

Lado C., Wrigley de Basanta D., Estrada-Torres A. \& García-Carvajal E. 2014. Myxomycete diversity of the Patagonian Steppe and bordering areas in Argentina. Anales del Jardín Botánico de Madrid 71: e006. https://doi.org/10.3989/ajbm.2394

Lado C., Wrigley de Basanta D., Estrada-Torres A. \& Stephenson S.L. 2016. Myxomycete diversity in the coastal desert of Peru with emphasis on the lomas formation. Anales Jardín Botánico de Madrid 73 (1): e032. https://doi.org/10.3989/ajbm.2436

Lado C., Estrada-Torres A., Wrigley de Basanta D., Schnittler M. \& Stephenson S.L. 2017. A rapid biodiversity assessment of Myxomycetes from a primary tropical moist forest of the Amazon basin in Ecuador. Nova Hedwigia 104 (1-3): 293-321. https://doi.org/10.1127/nova hedwigia/2016/0372

Léveillé J.H. 1863. Fungi. In Triana J. \& Planchon J.E., Prodromus Florae Novo-Granatensis. Annales des Sciences Naturelles, Botanique, sér. 4 20 (5): 282-300. https://doi.org/10.5962/bhl.title.5385

Lizárraga M., Moreno G., Esqueda M., Salazar-Márquez C. \& Coronado M.L. 2015a. Myxomycetes of Sonora (Mexico) 6 . Central plains of the Sonoran Desert. Mycotaxon 130: 145-164. https://doi.org/10.5248/130.145

Lizárraga M., Moreno G., Esqueda M., Salazar-Márquez C. \& Coronado M. 2015b. Myxomycetes of Chihuahua (México) 4. Central plains of the Chihuahuan desert. Mycotaxon 130 (4): 1073-1101. https://doi.org/10.5248/130.1073

Martin G.W. \& Alexopoulos C.J. 1969. The Myxomycetes. University of Iowa Press, Iowa.

McHugh R. 2009. Field and moist chamber collections of Paraguay myxomycetes. Karstenia 48: 49-56. https://doi.org/10.29203/ka.2009.428

MINAM 2015 [Ministerio del Ambiente, Dirección General de Evaluación, Valoración y Financiamiento del Patrimonio Natural]. Mapa nacional de cobertura vegetal: memoria descriptiva. TIPSAL S.A.C., Lima.

Moreno G., Illana C. \& Lizárraga M. 2001. SEM studies of the Myxomycetes from the Peninsula of Baja California (Mexico), III. Additions. Annales Botanici Fennici 38: 225-247.

Moreno G., Lizárraga M. \& Illana C. 2007. Catálogo de los Myxomycetes de México. Boletín de la Sociedad Micológica de Madrid 31: 187-229.

Moreno G., Castillo A., Sánchez A., Illana C. \& Oltra M. 2009. A new species of Physarum (Myxomycetes) from Mediterranean areas. Boletín de la Sociedad Micológica de Madrid 33: 137-148.

Moreno G., Castillo A., Deschamps J.R., Giménez G., Hladki A. \& LópezVillalba A. 2015. Critical revision on some Myxomycetes deposited in the Buenos Aires herbaria BAFC, BA and the Tucuman herbarium Lil. IV. Boletín de la Sociedad Micológica de Madrid 39: 129-140. https://doi.org/10.5248/123.63

Moreno G., Castillo A., López-Villalba A. \& Sánchez A. 2017. A new species of Hemitrichia in succulent plants. Boletín de la Sociedad Micológica de Madrid 41: 31-35.

Mosquera J., Lado C., Estrada-Torres A., Beltrán-Tejera E. \& Wrigley de Basanta D. 2003. Description and Culture of a new Myxomycete, Licea succulenticola. Anales del Jardín Botánico de Madrid 60 (1): 3-10. https://doi.org/10.3989/ajbm.2002.v60.i1.67

Nannenga-Bremekamp N.E. 1967. Notes on Myxomycetes. XII. A revision of the Stemonitales. Proceedings Koninklijke Nederlandse Akademie van Wetenschappen Series C 70 (2): 201-216.

Nannenga-Bremekamp N.E. 1975. De Nederlandse Myxomyceten. Bibliotheek van de Koninklijke Nederlandse Natuurhistorische Vereniging 18: 1-440. https://doi.org/10.2307/938611

Nannenga-Bremekamp N.E. 1989. Notes on myxomycetes XXIII. Proceedings Koninklijke Nederlandse Akademie van Wetenschappen Series C 92 (4): 505-515.

Nannenga-Bremekamp N.E. 1991. A guide to temperate Myxomycetes. Biopress Limited, Bristol.

Nannenga-Bremekamp N.E. \& Yamamoto Y. 1983. Additions to the Myxomycetes of Japan. I. Proceedings Koninklijke Nederlandse Akademie van Wetenschappen Series C 86 (2): 207-241.

Nannenga-Bremekamp N.E. \& Yamamoto Y. 1987. Additions to the Myxomycetes of Japan. III. Proceedings Koninklijke Nederlandse Akademie van Wetenschappen Series C 90 (3): 311-349.

Nannenga-Bremekamp N.E., Mukerji K.G. \& Pasricha R. 1984. Notes on Indian Myxomycetes. Three new species, and comments on others. Proceedings Koninklijke Nederlandse Akademie van Wetenschappen Series C 87 (4): 471-482.

Neubert H., Nowotny W. \& Baumann K. 1993. Die Myxomyceten Deutschlands und des angrenzenden Alpenraumes unter besonderer Berücksichtigung Österreichs. Band 1. Ceratiomyxales, Echinosteliales, Liceales, Trichiales. Karlheinz Baumann Verlag, Gomaringen. https://doi.org/10.1002/biuz.19940240622

Ostolaza C. 2014. Todos los cactus del Perú. Franco Eirl, Rimac.

Rojas C. \& Stephenson S.L. 2013. Effect of forest disturbance on myxomycete assemblages in the southwestern Peruvian Amazon. Fungal Diversity 59: 45-53. https://doi.org/10.1007/s13225-012-0181-x

Rojas C., Schnittler M. \& Stephenson S.L. 2010. A review of the Costa Rican myxomycetes (Amebozoa). Brenesia 73-74: 39-57.

Rojas C., Stephenson S.L. \& Pavlich M. 2011. New additions to the myxobiota of Peru. Mycosphere 2 (5): 583-592. https://doi.org/10.5943/mycosphere/2/5/8 
Rojas C, Valverde R. \& Stephenson S.L. 2015. New additions to the myxobiota of Costa Rica. Mycosphere 6 (6): 709-715. https://doi.org/10.5943/mycosphere/6/6/6

Rojas C., Morales R., Walker L.M. \& Valverde R. 2017. New records of myxomycetes for Central America and comments on their regional distribution. Journal on New Biological Reports 6 (2): 63-70.

Rossman A.Y., Tulloss R.E., O’Dell T.E. \& Thorn R.G. 1998. Protocols for an all taxa biodiversity inventory of Fungi in a costa rican conservation area. Parkway Oublishers Inc., Boone. https://doi.org/10.2307/3761287

Sheskin D.J. 2004. Handbook of parametric and nonparametric statistical procedures ed. 3. Chapman \& Hall, Boca Raton.

Stephenson S.L., Kalyanasundaram I. \& Lakhanpal T.N. 1993. A biogeographical comparative study of myxomycetes in the midAppalachians in the esastern North America and two regions of India. Journal of Biogeography 20: 645-657. https://doi.org/10.2307/2845520

van Hooff, J.P.M. 2009. Cribraria tecta, a new myxomycete from Vietnam. Boletín de la Sociedad Micológica de Madrid 33: 129-136.

Wrigley de Basanta D. 2004. The effect of simulated acid rain on corticolous myxomycetes. Systematics and Geography of Plants 74(1) $175-181$.

Wrigley de Basanta D. \& Estrada-Torres A. 2017. Techniques for recording and isolating Myxomycetes. In Stephenson S.L. \& Rojas C. (eds.), Myxomycetes: Biology, Systematics, Biogeography, and Ecology: 333-363. Academic Press, Elsevier, London. https://doi.org/10.1016/b978-0-12-805089-7.00010-X

Wrigley de Basanta D., Stephenson S.L., Lado C., Estrada-Torres A. \& Nieves-Rivera A.M. 2008a. Lianas as a microhabitat for myxomycetes in tropical forests. Fungal Diversity 28: 109-125. https://doi.org/10.1007/s13225-013-0236-7

Wrigley de Basanta D., Lado C. \& Estrada-Torres A. 2008b. Morphology and life cycle of a new species of Didymium (Myxomycetes) from arid areas of Mexico. Mycologia 100 (6): 921-929. https://doi.org/10.3852/07-168

Wrigley de Basanta D., Lado C., Estrada-Torres A. \& Stephenson S.L. 2009. Description and life cycle of a new Didymium (Myxomycetes) from arid areas of Argentina and Chile. Mycologia 101 (5): 707-716. https://doi.org/10.3852/08-227

Wrigley de Basanta D., Lado C. \& Estrada-Torres A. 2010a. Licea eremophila, a new myxomycete from arid areas of South America. Mycologia 102 (5): 1185-1192. https://doi.org/10.3852/09-309

Wrigley de Basanta D., Lado C., Estrada-Torres A. \& Stephenson S.L. 2010b. Biodiversity of myxomycetes in subantarctic forests of Patagonia and Tierra del Fuego, Argentina. Nova Hedwigia 90: 45-79. https://doi.org/10.1127/0029-5035/2010/0090-0045

Wrigley de Basanta D., Lado C. \& Estrada-Torres A. 2011. Spore to spore culture of Didymium operculatum, a new myxomycete from the Atacama Desert of Chile. Mycologia 103 (4): 895-903. https://doi.org/10.3852/10-363

Wrigley de Basanta D., Lado C. \& Estrada-Torres A. 2012. Description and life cycle of a new Physarum (Myxomycetes) from the Atacama Desert in Chile. Mycologia 104 (5): 1206-1212. https://doi.org/10.3852/11-427

Wrigley de Basanta D., Lado C., Estrada-Torres A. \& Stephenson S.L. 2013. Biodiversity Studies of Myxomycetes in Madagascar. Fungal Diversity 59: 55-83. https://doi.org/10.1007/s13225-012-0183-8

Wrigley de Basanta D., Lado C., García-Martín J.M. \& Estrada-Torres A. 2015. Didymium xerophilum, a new myxomycete from the tropical Andes. Mycologia 107 (1): 157-168. https://doi.org/10.3852/14-058

Wrigley de Basanta D., Estrada-Torres A., García-Cunchillos I., Echeverría A.C. \& Lado C. 2018. Didymium azorellae, a new myxomycete from cushion plants of cold arid areas of South America. Mycologia 109 (6): 993-1002. https://doi.org/10.1080/00275514.2018.1426925

Wrigley de Basanta D., Estrada-Torres A., \& Lado C. 2019. Licea aurea a new Myxomycete from the Peruvian Andes. Phytotaxa 391 (3): 218-224. https://doi.org/10.11646/phytotaxa.391.3.5

Zar J.H. 1996. Biostatistical Analysis ed. 3. Prentice Hall Inc., Upper Saddle River.

Zúñiga R.A. 2010. Registro preliminar de Myxomycetos en la selva central delPerú.Biotempo 10:15-17.https://doi.org/10.31381/biotempo.v10i0.849 